\title{
Transparency in Central Bank Financial Statement Disclosures
}

\author{
Edited by Kenneth Sullivan
}




\title{
IMF Working Paper
}

Monetary and Financial Systems Department

\section{Transparency in Central Bank Financial Statement Disclosures}

\author{
Prepared by Kenneth Sullivan ${ }^{1}$
}

Authorized for distribution by Arne B. Petersen

April 2005

\begin{abstract}

\section{This Working Paper should not be reported as representing the views of the IMF.} The views expressed in this Working Paper are those of the author(s) and do not necessarily represent those of the IMF or IMF policy. Working Papers describe research in progress by the author(s) and are published to elicit comments and to further debate.

The IMF's development of the Code of Good Practices on Transparency in Monetary and Financial Policies and the introduction of safeguards assessments have increased emphasis on transparency of the disclosures made in central bank financial statements. This paper, which updates WP/00/186, looks at the disclosure requirements for central banks under International Financial Reporting Standards and provides practical guidance for those responsible for preparing central bank financial statements.
\end{abstract}

JEL Classification Numbers: G29

Keywords: central bank, financial statements, disclosure, transparency, IAS

Author(s) E-Mail Address: ksullivan@imf.org

\footnotetext{
${ }^{1}$ This Working Paper is based on papers_-presented to a central bank accounting workshop held at the Joint Vienna Institute (JVI), Vienna, in April 2000 — by Janet Cosier (Bank of Canada), Freidrich Karrer (Austrian National Bank), Richard Perry (Reserve Bank of New Zealand), Arne B. Petersen (IMF), and Kenneth Sullivan (IMF).
} 
I. Introduction 4

II. Transparency In Strengthening The International Monetary System and The Role of The IMF .5

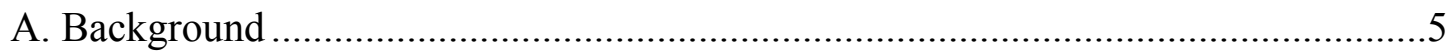

B. The Code - Its Underlying Rationale and Main Elements....................................5

C. Transparency in Financial Statements of Central Banks .......................................

III. Applying IAS 1 And IAS 30 To Central Bank Financial Reporting .............................8

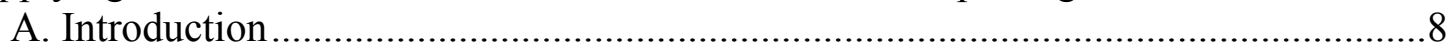

B. Overview of the External Reporting Model .......................................................... 9

C. The Role and Components of Financial Statements ..........................................11

D. Users of Central Bank Financial Statements and their Needs ..............................12

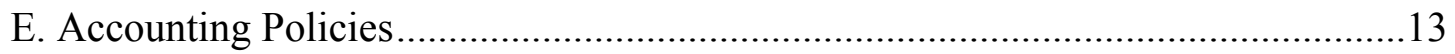

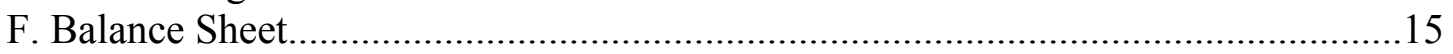

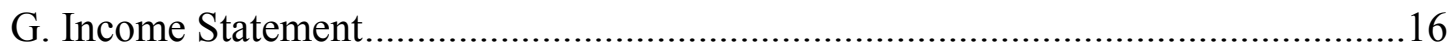

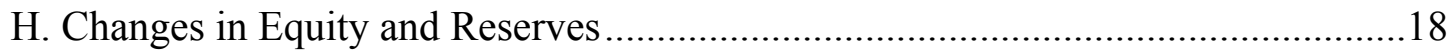

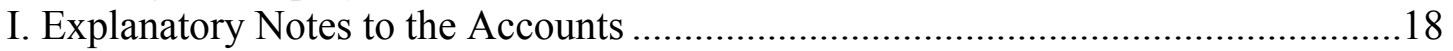

IV. IAS 32 Financial Instruments: Disclosure And Presentation-Case Study Of The Reserve Bank of New Zealand ......................................................................... 19

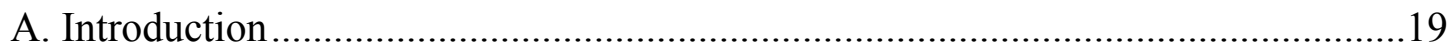

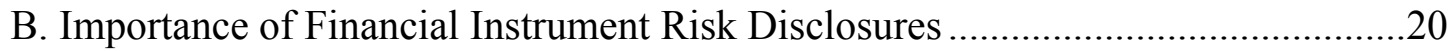

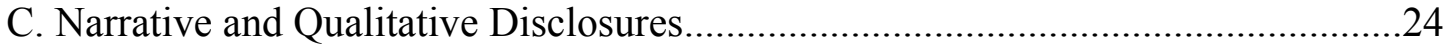

D. Quantitative Disclosures for Financial Instruments ...........................................29

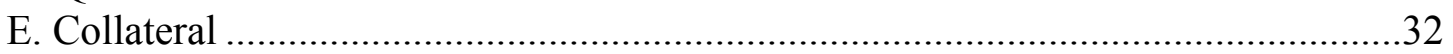

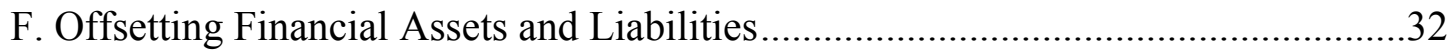

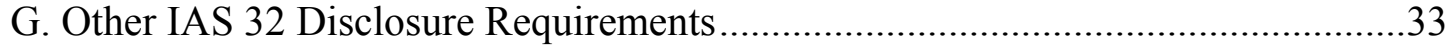

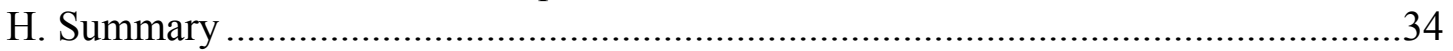

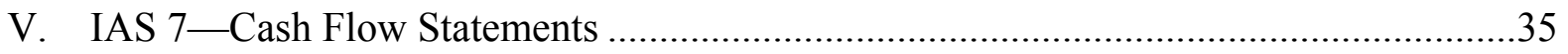

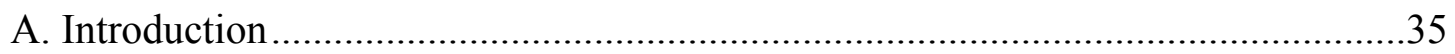

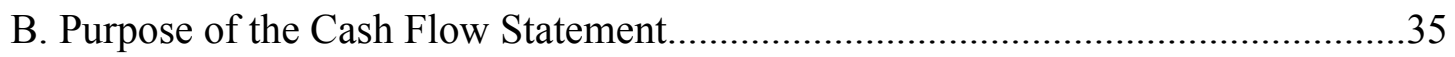

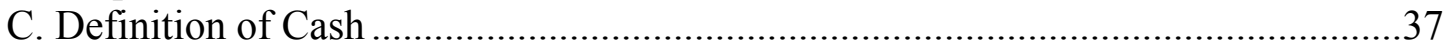

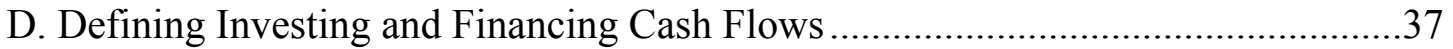

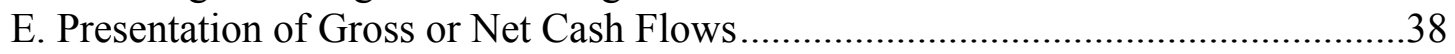

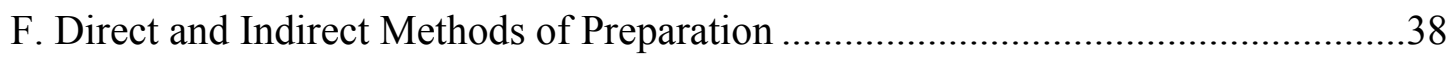

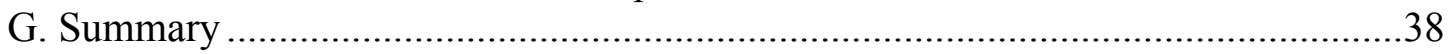

Appendices

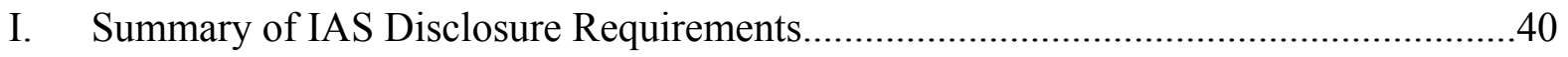

II. Reserve Bank of New Zealand-Financial Statements 2002-2003 _...........................67 
III. IAS 39 Financial Instruments: Recognition and Measurement................................120

IV. IAS 21-The Effect of Changes in Foreign Exchange Rates...................................128

V. Difference between the Accounting and Reporting Principles in the Eurosystem and the International Financial Reporting Standards (IFRS) 


\section{INTRODUCTION}

The theme for this paper is transparency in central bank financial statement disclosures. While the emphasis is on transparency in the accounting framework and disclosure practices of central banks, it is appropriate to set the broader framework for transparency. The financial crises in Asia convinced the IMF of the value of transparency, which it has set out to promote under the development of the Code of Good Practices on Transparency in Monetary and Financial Policies. ${ }^{2}$

The introduction of safeguard assessments for users of IMF resources has also increased the importance of transparent reporting in compliance with International Financial Reporting Standards (IFRS). ${ }^{3}$ This paper offers practical guidance to those responsible for preparing central bank financial statements to enable the publication of statements consistent with international standards.

The working paper is based on the papers presented to a central bank accounting workshop held at the Joint Vienna Institute (JVI) in Vienna in April 2000 and updated in May 2004 to reflect amendments to relevant IFRS. ${ }^{4}$ Contributors to the paper are Janet Cosier (Bank of Canada), Friedrich Karrer (Austrian National Bank), Richard Perry (Reserve Bank of New Zealand), Arne Petersen (IMF) and Kenneth Sullivan (IMF).

As an example of good disclosure, the paper adopts the 2003 Financial Statements for the Reserve Bank of New Zealand (RBNZ). For a series of years, the RBNZ has won first prize for its annual report in their category in a national competition run by the Institute of Chartered Accountants of New Zealand. Following the sections on relevant disclosures, the paper presents a series of appendices that map out how IFRS are reflected in the RBNZ 2003 Financial Statements, providing a replication of the RBNZ 2003 Financial Statements as well as two appendices that cover accounting issues relevant to central banks arising from the application of IAS 39 Financial Instruments: Recognition and Measurement and IAS 21 The Effects of Changes in Foreign Exchange Rates. The sections, where appropriate, should be read with reference to these appendices. The RBNZ financial statements may also be viewed on the RBNZ web site at www.rbnz.govt.nz.

\footnotetext{
${ }^{2}$ Available on the IMF external web page, along with the supporting document at www.imf.org/external/np/mae/mft/index.htm.

${ }^{3}$ IFRS replaced International Accounting Standards (IAS) as the international accounting framework. IFRS subsume the remaining individual IAS that have not been reviewed and reissued as IFRS.

${ }^{4}$ Richard Perry (formerly Reserve Bank of New Zealand) performed the update.
} 


\section{Transparency In STREngthening The InTERnational MONETARY SySTEM AND THE ROLE OF THE IMF}

\section{A. Background}

The successive financial crises in different regions of the world over the past two decades have led to much reflection and analysis in various international bodies on ways to strengthen the international financial system. A special G-22 Working Group on Transparency and Accountability was formed in 1998 to focus particular attention on this topic, and it issued a comprehensive report.

A consensus has emerged that inadequate transparency by international organizations, national governmental units, and private sector entities was a contributing force to the serious financial disturbances that have plagued the global economy. The conclusion was reached that markets cannot function efficiently, and that they will continue to be highly vulnerable to instability, in the absence of adequate, reliable, and timely information from all quarters. Lack of accurate and timely information on economic and financial developments and policies, particularly in an environment of economic and financial weakness, aggravates the weakness and contributes to the emergence of crises situations.

From this discussion, the IMF produced the Code of Good Practices on Transparency in Monetary and Financial Policies. In addition, the Fund continues to develop its Special Data Dissemination Standards (SDDS) as another avenue for enhancing international transparency.

Specialist standard-setting bodies dealing with other financial sector-related areas (such as accounting, auditing, banking regulation and supervision, bankruptcy, corporate governance, insurance regulation, payment system and securities market regulation) are also active in developing standards relevant for a better functioning financial system. The focus of these standards typically is broader than transparency. However, transparency and disclosure practices are covered in these standards as well, and thus have relevance to the Fund's Code of Good Practices on Transparency in Monetary and Financial Policies.

\section{B. The Code - Its Underlying Rationale and Main Elements}

What is meant by transparency? For purposes of the Code, transparency for central banks refers to an environment in which the objectives of monetary policy, its legal, institutional, and policy framework, monetary policy decisions and their rationale, data and information related to monetary policies, and the terms of central bank accountability are provided to the public on an understandable, accessible and timely basis. Thus, the code covers a much wider area than transparent accounting. However, transparency in accounting is the basis on which other elements rest.

${ }^{5}$ Prepared by Arne B. Petersen and Kenneth Sullivan. 
The Code covers both monetary policies and financial policies (i.e., the policies related to the regulation, supervision, and oversight of banking, insurance, securities, payment systems, and deposit insurance). These two sets of policies are interrelated and often mutually reinforcing. The full benefits to be derived from good transparency practices in the monetary policy area cannot be achieved without complementary good transparency practices in the financial policy area, and vice versa. This section focuses on the part related to central banks.

The first part of the Code, "Good Transparency Practices for Monetary Policy by Central Banks," is organized into four sections, each representing an aspect of transparency practices: (1) clarity of roles, responsibilities, and objectives of central banks; (2) the processes for formulating and reporting monetary policy decisions; (3) public availability of information on monetary policies; and (4) accountability and assurances of integrity by the central bank.

The design of transparency practices for central banks in the Code rests on two principles. First, monetary policies can be made more effective if the public knows and understands the goals and instruments of policy and if the authorities make a credible commitment to meeting them. Second, good governance calls for central banks to be accountable, particularly where monetary authorities are granted a high degree of autonomy. By publishing adequate information about its activities, the central bank can establish a mechanism for strengthening its credibility by matching its actions to its public statements. It is here that the transparency code and the accounting function intersect. Central bank accounting and reporting systems must be set up in such a way that the central bank provides the public with meaningful and transparent information.

Chairman Alan Greenspan of the U.S. Federal Reserve Board, at the Tercentenary Symposium of the Bank of England in 1994, reflected on the case for transparency for central banks in the following insightful manner:

\footnotetext{
.... if we are going to have independent central banks then implicit in that independence is accountability. You cannot in a democratic society have an institution which is fully or partly dissociated from the electoral process and which has powers that central banks inherently have. The question really amounts to how does one position the central bank with respect to the issue of disclosure and accountability—which are related questions.

\begin{abstract}
The position that we [the Federal Reserve] take is that the burden of proof is against the central bank: that is, we have to demonstrate that either delayed disclosure or nondisclosure is a policy which is required for us to implement our statutory goals. We have struggled with this, and have concluded that we should make available to the electorate what it is we think, why we are doing what we are doing and in a general way under what conditions we would behave differently" (pp. 252-53, Forest Capie, Charles Goodhart, Stanley Fischer, and Norbert Schnadt, The Future of Central Banking, Cambridge University Press, 1994).
\end{abstract}

Transparency for central banks is not an end in itself, nor should transparency be considered as a substitute for pursuing sound policies. Transparency and sound policies should be seen as complements. 


\section{Transparency in Financial Statements of Central Banks}

The annual report, including the annual financial statements, is a key for central banks to meet their accountability obligations. These statements reveal the results of the central bank's functional activities on its balance sheet as well its use of the resources at its disposal. One does not need to look far to see examples of where the central bank's financial reports have been used by opposition politicians to launch criticisms of both the government and central bank. As the ability to question performance is an essential component of accountability, those preparing annual financial statements carry the responsibility of presenting them so that they provide an accurate picture of the financial results of central bank operations in a manner that can be defended in terms of an internationally credible framework. Such presentation will direct criticism to appropriate areas, so reducing the possibility of the independence of the central bank being constrained and its operational effectiveness reduced.

Experience repeatedly shows that the best defense to criticism is through open and transparent disclosure, since this removes the risk of the hugely damaging consequences that occur when it is revealed that disclosures have been less than total. It is difficult to overstate the importance of the role of transparency in ensuring the maintenance of central bank independence and discharging its accountability obligations.

The importance of transparent reporting practices for central banks extends beyond narrow institutional interests because they make an important contribution to establishing the credibility of a nation's financial system. As economies evolve and seek to establish their positions in the international market place, the national reporting framework becomes important to an expanded group of users. Central bank financial statements may be published or posted on the Internet where they can be read internationally. Opinions formed on the robustness of financial reporting frameworks from reading such documents contribute to judgments about the integrity and stability of the national financial system.

In the absence of a well-developed set of generally accepted accounting practices (GAAP) within a country, the published reports of authoritative institutions are used to determine what is best practice. By default, central bank disclosures make a material contribution to what is accepted as the nation's GAAP, as commercial banks and other financial sector participants adopt them. Transparent central bank financial statements make it easier for bank supervisors to demand a similar level of disclosure from the commercial banks that they supervise. Transparent disclosures by commercial banks are an integral part of the process of establishing and maintaining a robust framework for the commercial banking system. In situations of emerging systems of GAAP, central banks have a valuable role to play in advancing the level of clarity and openness of disclosure.

For most transition economies, the accounting profession and the standard-setting framework in terms of market-based disclosures are still evolving. This can create potential problems for the production of internationally credible financial reports. Those who are not market participants and who have a conflict of interest, such as maximizing taxable revenue, may 
control standard setting. The section recognizes these tensions and seeks to enhance understanding of the conceptual framework upon which central banks base their reporting.

The basis of the section's framework is the IFRS because these provide an agreed minimum conceptual framework for reporting. IFRS evolved from demands by the international marketplace and are gaining increasing acceptance as the foundation from which all national standards should evolve. Despite some issues for central banks, particularly in the treatment of price and foreign exchange revaluations of financial instruments, their international credibility provides a robust framework upon which to base and defend financial disclosures.

\section{APPlying IAS 1 ANd IAS 30 to CENTRAL BANK FinANCIAL REPORTING ${ }^{6}$}

\section{A. Introduction}

This section provides an overview of issues associated in applying International Accounting Standard 1-Presentation of Financial Statements (IAS 1) and International Accounting Standard 30-Disclosures in the Financial Statements of Banks and Similar Financial Institutions (IAS 30) to central bank financial reporting. The issues discussed include:

- an overview of the external reporting model, types of information to be disclosed and the reasons it is required in market economies;

- the role and main components of financial statements including the fundamental concepts for preparing financial statements;

- users of central bank financial statements and their needs; and

- issues in applying aspects of IAS 1 and IAS 30 to each of the main components of the financial statements. This excludes the Statement of Cash Flows, which is subsequently discussed. ${ }^{7}$

This section should be considered in conjunction with the detailed requirements of IAS 1 and IAS 30. These detailed requirements are presented in Appendix I, which has been designed to assist with the preparation of central bank financial statements in accordance with IAS 1 and IAS $30 .^{8}$

\footnotetext{
${ }^{6}$ Prepared by Richard Perry.

${ }^{7}$ Section V, "International Accounting Standard 7-Statement of Cash Flows.”

${ }^{8}$ See Appendix I, "Summary of International Accounting Standard Disclosure Requirements-IAS 1, IAS 7, IAS 21, IAS 30, IAS 32, and IAS 39."
} 


\section{B. Overview of the External Reporting Model}

Public and private sector entities are in business for a variety of reasons such as profit maximization or the achievement of outcomes that can benefit society. The business process will involve each entity entering various business arrangements and transacting with one another in the exchange and consumption of economic resources. These business transactions can range from relatively simple to extremely complex and can be completed in different countries with different laws governing the business arrangements and transactions.

Parties entering business arrangements will be concerned about the overall financial health of the entities with which they undertake business, including the ability of the entity to pay any amounts owing to them, whether the entity will continue to exist in the future, how successful the entity has been in generating profits, and the risks the entity has exposed itself to in various business undertakings. More specifically, external parties will seek information about an entity's business transactions and performance in order to:

- make decisions about providing resources to, or doing business with, the entity;

- assess management's stewardship of the resources entrusted to it;

- assess the entity's current and potential ability to generate profits and cash flows; and

- assess the entity's compliance with laws and business contracts to the extent that these affect the outcomes the entity is seeking to achieve.

External parties will generally obtain the above information from the entity's annual report, which includes general-purpose financial statements. General-purpose financial statements are intended to provide information to users who are not in a position to demand tailored financial reports to meet their specific information needs. This reflects that some users are unable to extract relevant and timely information from their business partners in order to make decisions. Hence, they must rely on the information contained in the financial statements as their major source of financial information to assist them in their decision making. Users that have specific custodial or transaction monitoring requirements are usually able to contract for their specific information purposes as part of the business contract. An example of a specific financial information need is a commercial bank that can require a party to a loan agreement to provide specific information before the loan is provided.

The need for general-purpose financial statements is well recognized internationally. For example, most countries require public companies to publish regular financial statements as a condition of company registration. This is to ensure that information is provided:

- that is useful to present and potential investors, creditors, and other users in making rational investment, credit, and similar decisions;

- to help current and potential investors, creditors, and other users in assessing the amounts, timing, and uncertainty of prospective cash receipts from dividends or interest; 
the proceeds from the sale, redemption, or maturity of securities or loans; the entity's capital transactions and other factors that affect liquidity;

- about the economic resources of an entity, the claims to those resources, and the effects of transactions, events, and circumstances that change resources and claims to those resources;

- about an entity's financial performance given by measures of earnings and its components in order to help in assessing the prospects of an entity;

- about how management has discharged its responsibility to shareholders for the stewardship of the entity's resources; and

- that is useful to management in making decisions in the interest of shareholders.

In addition, it is important to consider the connection between developments in financial markets and the consequences for financial reporting. It is generally accepted that, in an efficient market, security and share prices impound all publicly available information. Lack of timely and accurate information can distort prices and heighten uncertainty. This in turn can lead to increases in financial contracting costs as capital providers and capital users try to protect themselves against information uncertainties. It can also lead to costly litigation after the fact, if it may be alleged that vital information was missing or presented an inaccurate picture of the state of the entity's affairs. In summary, information uncertainties can increase the cost of capital to an entity.

To reduce the likelihood of information uncertainties arising, common frameworks for financial reporting have been developed to facilitate the provision of consistent and reliable financial information. IFRS are accepted as the global standard for financial reporting that provides financial information to meet the diverse needs of general users who cannot require the business entity to provide specific information. IFRS are standards and interpretations adopted by the International Accounting Standards Board and comprise:

- International Financial Reporting Standards;

- International Accounting Standards; and

- Interpretations originated by the International Financial Reporting Interpretation Committee or the former Standing Interpretation Committee.

Users of financial statements generally expect compliance with IFRS, and this is likely to assist entities to avoid the information uncertainties that can otherwise increase the cost of capital. 


\section{The Role and Components of Financial Statements}

IAS 1 describes financial statements as a structured financial representation of the financial position and financial performance of an entity. The objective is to provide information about the financial position, financial performance and cash flows of an entity that is useful to a wide range of users in making economic decisions. Financial statements also show the results of management's stewardship of the resources entrusted to it. To meet this objective, financial statements provide information about an entity's:

- assets;

- liabilities;

- equity;

- income and expenses, including gains and losses;

- other changes in equity; and

- cash flows.

This information, along with other information in the notes to financial statements, assists users to predict the entity's future cash flows and in particular the timing and certainty of the generation of cash and cash equivalents.

IAS 1 explains that a complete set of financial statements includes:

- accounting policies;

- a balance sheet;

- an income statement;

- a statement showing either all changes in equity or changes in equity other than those arising from transactions with equity holders acting in the capacity of equity holders;

- a cash flow statement; and

- explanatory notes.

These financial statement components interrelate because they reflect different aspects of the same transactions or other events. Although each component provides information that is different from the others, none is likely to serve only a single purpose or provide all the information needs for all users. Hence, the information contained in the notes to the accounts 
is of equal importance as the major statements such as the balance sheet and income statement.

In addition, IAS 1 outlines fundamental concepts for account preparation including:

- Going concern. The assumption that the business will continue to operate into the future (i.e., the business will not be liquidated or cease trading).

- Accrual basis. Transactions are recognized as they occur and reported in the periods to which they relate. This recognizes that some cash outlays will benefit several future periods - for example, the purchase of an asset will provide benefits to future reporting periods and the costs of the asset are allocated to each period through capitalization and depreciation of the asset.

- Consistency. Presentation and classification of items in financial statements should be consistent between periods. Where the presentations or classifications are changed, the comparative information should be changed to reflect the new basis.

- Materiality. Each material item should be presented in the financial statements and immaterial items should be aggregated. It is important to recognize that materiality encompasses both materialities by amount and materiality by nature. For example, entering a low-value transaction may have extremely important risk consequences for the entity that are important to disclose to the users of the financial statements. In this context, information is material if nondisclosure is likely to influence the economic decisions of the financial statement users.

\section{Users of Central Bank Financial Statements and Their Needs}

To understand the specific objectives of central bank financial statements it is necessary to consider the users of the central bank financial statements and what information they require. For a central bank, the users include:

- The central bank stakeholders, including taxpayers and government. Stakeholders may be concerned with the central bank stewardship of public monies. Because central banks use public money, they have a responsibility to display an appropriate level of care in managing these funds and using resources efficiently to perform their functions. In particular, these users may wish to assess the accountability of management when deciding whether to reappoint or replace them. Given the increasing independence being granted to central banks, governments may use financial statements as a major means of applying central banks' accountability. Financial statements may also provide the basis for calculating the annual dividend to be paid to government.

- Commercial banks. Many central banks prescribe the external reporting requirements of commercial banks. Commercial banks may look to the central bank for examples of appropriate and best practice financial statement disclosure. 
- External suppliers and lenders. The central bank may purchase goods and services, or borrow funds, from other domestic and international suppliers who are interested in the ability of the central bank to meet their obligations as they fall due.

- Credit rating agencies and financial markets. The relative position of the central bank may provide information to credit rating agencies and financial markets on the resources of the central bank and the ability of the central bank to be effective in meeting its stated policy objectives. This may affect the overall credit rating of the country or risk premium demanded by international financial markets. For example, specific information may be sought on foreign reserves and the ability of the central bank to meet exchange rate objectives.

- Purchasers of central bank services. Central banks may provide certain services such as payment system mechanisms. Customers of these services will be interested in the extent to which the central bank provides these services on commercial terms and the level of profit generated by such services.

The needs of these users can generally be met by providing information on the:

- economic resources under control of the central bank;

- legal and economic obligations of the central bank;

- inflows and increases in economic resources and consumption or declines in economic resources of the central bank;

- cost information on central bank operations;

- future risks to the maintenance of the resources of the central bank;

- potential obligations and resources not yet measured by the central bank and why;

- level of transactions with parties related to the central bank including unconsolidated subsidiaries; and

- methods used to portray and measure the actual economic resources.

This information will generally be provided through various components of the central bank financial statements.

\section{E. Accounting Policies}

Accounting policies allow the users of central bank financial statements to understand how the economic resources of the central bank have been measured and portrayed in the financial statements. In particular, the accounting policies should describe the measurement basis used 
in preparing the financial statements and disclose each specific accounting policy that is necessary for a proper understanding of the financial statements.

It is suggested that the accounting policies should be the first component of the financial statements to be presented. This recognizes that the accounting policies will determine how the financial statements measure and portray the position and performance of the central bank. On this basis, they can be considered as the "window" through which the financial statements portray and interpret the actual events and transactions of the central bank.

In deciding whether a specific accounting policy should be disclosed, consideration should be given to whether disclosure would assist users in understanding the way in which transactions and events are reflected in the reported performance and financial position. For example, it is important to understand the basis on which assets are valued and how both realized and unrealized gains and losses are treated in the income statement and balance sheet.

An objective for preparers of central bank financial statements is to select accounting policies so that the financial statements comply with the requirements of IFRS. Where there is no specific requirement, accounting policies should ensure that the financial statements provide information that is relevant to the decision-making needs of users and are reliable in that they:

- faithfully represent the results and financial position of the central bank;

- reflect the economic substance of events and transactions;

- $\quad$ are neutral (that is, free from bias);

- $\quad$ are prudent; and

- are complete in all material respects.

Specific issues to consider in disclosing accounting policies include:

- Financial instruments. Financial instruments comprise a significant proportion of a central bank's economic resources and account for a significant amount of the overall financial performance. Financial instruments can be subject to various measurement practices (such as historic cost or market value) or may not even be recorded within the financial statements (i.e., they are off balance sheet). Consideration should be given to including detailed disclosure in the accounting policies of the way in which these financial instruments are accounted for, including the measurement base used and how they are recognized in the financial statements. The detailed disclosure is important to understanding how profit is measured and any implications that measurement may have for dividend calculation purposes. In addition, disclosure may provide an appropriate example for commercial bank disclosure because information on financial instrument 
recognition and measurement is an integral part to understanding the profitability and health of commercial banks.

- Changes in accounting policies. Accounting policies should also include an explanation on whether or not there have been changes made in any specific accounting policies. Where changes have been made, the reason should be disclosed, and the impact on the current and prior periods should be explained.

- Disclosure of supplementary information. The accounting policies are an appropriate location for disclosing other nonfinancial information required by IFRS, including the entity's name, legal status, the reporting group, whether the financial statements comply with IFRS, and whether the fundamental accounting assumptions such as accrual accounting and going concern have been applied.

\section{F. Balance Sheet}

The balance sheet reflects the economic resources under the control of the central bank and the legal and economic obligations of the central bank. This provides information on the financial structure, liquidity and solvency of the central bank.

The application of IAS 1 and IAS 30 to central bank balance sheets raises several issues including disclosure:

- of current and long-term categories of assets and liabilities versus disclosure in broad order of liquidity;

- in the face of the balance sheet or notes to accounts; and

- of equity and reserves.

\section{Current/noncurrent versus order of liquidity}

IAS 1 requires an entity to determine, based on the nature of its operations, whether or not to present current and noncurrent assets and current and noncurrent liabilities as separate classifications on the face of the balance sheet. When an entity chooses not to make this classification, assets and liabilities should be presented broadly in order of their liquidity. However, IAS 30 suggests banks should present a balance sheet that groups assets and liabilities by nature and lists them in an order that reflects their relative liquidity.

Central banks usually have significant levels of financial assets and liabilities. Hence, the presentation will be most appropriately made in broad order of liquidity, since many assets and liabilities will be able to be realized or settled in the near future. 


\section{Face of balance sheet versus notes to the accounts}

Both IAS 1 and IAS 30 detail several items that should be considered for disclosure on the face of the balance sheet. In determining the appropriate presentation on the face of the balance sheet, consideration should be given to how the presentation could best reflect the underlying business operations of the central bank. The objective would be for a user of the financial statements to be able to understand the significant economic resources and obligations of the central bank by reviewing the balance sheet.

For example, the RBNZ applies a distinction between local and foreign currency assets and liabilities. This reflects that the RBNZ holds foreign currency assets primarily for the purpose of managing New Zealand's foreign reserves. Local currency assets and liabilities arise from monetary policy implementation, banking operations, and provision of circulating currency. Within the local and foreign currency splits, assets and liabilities are presented in broad order of liquidity, and any specific items required to be disclosed by accounting standards are included either on the face of the balance sheet or in the notes to the accounts.

In addition, the RBNZ approach has been to identify a common set of balance sheet asset and liability definitions that are adopted throughout the notes to the accounts. Specifically, this allows disclosure relating to balance sheet risks (such as credit risk, interest rate risk and foreign currency risk) to be presented by a common set of balance sheet classifications. The conceptual rationale is that the same elements of the balance sheet can be considered in light of the different risks that arise. This allows users who seek information on specific risks, such as the RBNZ exposure to credit risk, to relate the balance sheet amounts to credit risk arising on those amounts.

Note also that the RBNZ has deliberately attempted to increase the transparency of balance sheet presentation through disclosure of summarized explanation of major balance sheet changes and references to the notes to the accounts for further information.

\section{Equity and reserves}

IAS 1 details several disclosures required in the balance sheet with respect to share capital. These disclosures may not be applicable to central bank circumstances given that central banks are not always funded through share capital.

Disclosure of reserve information is very important in central bank circumstances to allow users to understand the reasons why reserves are maintained. This disclosure should be accompanied by a description of the nature and purpose of each reserve class.

\section{G. Income Statement}

The income statement provides information concerning the performance of the central bank and, in particular, its profitability. This information can assist understanding how economic 
resources have been increased and consumed by the central bank. In addition, central banks may charge for the provision of certain services (such as banking services to the public sector and government). Profit information allows users to understand the extent to which the profit generated from these activities is excessive or comparable to the profits generated by commercial suppliers of similar services.

However, the disclosure of central bank profit is usually an inappropriate measure of central bank performance. This is relevant where central bank profit arises largely from the consequences of implementing monetary policy and from the monopoly issue of circulating currency. The profit generated in these circumstances will arise usually as a consequence of the monetary policy actions of the central bank. The central bank may influence interest rates in order to achieve inflation objectives, and the profit the central bank earns as a consequence of the monetary policy actions is secondary to achieving the inflation objectives. A better measure of performance in these circumstances is information that explains the inflation objectives and the success of the central bank in meeting the inflation objectives. The more important financial information is the operating costs the central bank has incurred in achieving these inflation objectives.

The disclosure of cost information is usually a better indicator of financial performance because it demonstrates whether the central bank has been efficient in achieving its policy objectives. For example, has central bank spending been appropriate given the policy objectives? Disclosure of cost information allows users to review the central bank stewardship of public resources. This disclosure of cost information can be used to demonstrate that the central bank has been efficient and responsible in using public resources. This can enhance the central bank's credibility and reduce the potential for political interference. Hence, the disclosure of central bank cost information can contribute to obtaining and preserving greater central bank independence.

Consideration can be given to complementing the traditional income statement with a statement that discloses financial performance by reference to the material business operations of the central bank. This approach can refer to the "outputs" or goods and services that the central bank produces and may satisfy the functional presentation requirements suggested by IAS 1 , but is not a specific requirement of IAS 1 or IAS 30 . The RBNZ presents two income statements, one in the traditional fashion and one by reference to the outputs of the RBNZ. These statements include performance relative to budget and explain any significant budget variances to enhance transparency.

IAS 1 and IAS 30 prescribe certain information to be included on the face of the income statement or in the notes to the accounts. The IAS 30 classifications are more appropriate to central bank circumstances, since the IAS 1 approach is the more traditional approach designed for businesses that make and sell physical goods. The IAS 1 approach uses a "gross profit" concept where information is provided on income generated by sales of goods less the cost of purchasing or making those goods. The net of this income and cost is the "gross profit" of the entity that is available to meet operating costs before profit is calculated. 
However, the application of the IAS 30 approach should be tailored to the specific circumstances of the central bank. The IAS 30 approach primarily facilitates analysis of profitability from a commercial bank perspective. In particular, the approach has been designed to allow analysis of commercial banks' interest rate margin (i.e., the margin earned through the lending and borrowing money in the banking process), trading activities, and fee income. These profit categories are usually not as relevant to central bank circumstances given the nonprofit objectives of central banks.

\section{H. Changes in Equity and Reserves}

This statement explains the changes in the central bank's equity and reserves, including distributions to stakeholders, increases of equity (by way of retained earnings or contributions by stakeholders), and changes in various reserves.

\section{Explanatory Notes to the Accounts}

The financial statements also contain notes, supplementary schedules, and other information that is relevant to the needs of users. This will include information concerning future risks to the maintenance of the resources of the central bank, potential obligations and resources not recognized in the financial statements of the central bank, and the reasons why these potential obligations are not recognized.

Information that is not included on the face of the balance sheet or income statement should be included in the notes to the accounts. Each item on the face of the balance sheet should be cross-referenced to any related information in the notes.

IAS 30 contains specific disclosures to be included in the notes to the accounts. The specific disclosures include:

- Contingencies and commitments (IAS 30, para. 26). This is to report any obligations not recognized in the financial statements and provides information concerning off balance sheet transactions, potential obligations that may affect liquidity and solvency, and potential losses that are not recognized. The information is extremely important because it allows users to understand any potential obligations of the central bank that are not currently recognized in the financial statements. These potential obligations may affect future central bank finances and disclosure should be sufficiently comprehensive and detailed to allow financial statement users to assess the probability and impact of any potential obligations. For example, a central bank may have provided guarantees for third-party lending that could have a material impact on the central bank in the event of third-party default. Even if the probability of the guarantee being exercised was low, the financial statements should describe the nature and amount of the guarantee and the circumstances governing its exercise. This provides the central bank with some defense in the event that the guarantee was exercised, which substantially reduced a future dividend payment to government. 
- Maturity analysis of assets and liabilities (IAS 30, para. 30). This information allows users to assess the ability of the entity to meet obligations as they fall due and understand the overall liquidity of the entity.

- Concentrations of assets and liabilities (IAS 30, para. 40). Disclosure of significant concentrations by geography and industry assists users to assess the degree of exposure the entity has to any one sector. This is important to understand the risks the organization may face if a particular region/country or industry experiences financial difficulties.

- Significant net foreign currency exposures (IAS 30 para. 40). There is a requirement to disclose significant net foreign currency exposures to provide information regarding the degree of foreign currency risk the entity faces. A significant net foreign currency concentration exposes an entity to the risk arising from changes in foreign currency rates. Central banks may have significant net foreign currency exposures arising from the management of foreign reserves.

- Losses on loans and advances (IAS 30, para. 43). This allows users to assess the effectiveness of the entity in managing and providing for loan losses and in recovering outstanding loans to customers.

- General banking risks (IAS 30, para. 50). This information provides users with an understanding of items such as general provisions for loan losses.

- Assets pledged as security (IAS 30, para. 53). Banks will often pledge assets as collateral for borrowing money. A common example is repurchase agreements, where money is advanced to external parties after an entity passes legal title of the assets (usually marketable securities) to the counterparty. The purpose of this disclosure is to allow readers to determine the value of assets available to creditors and the ability of the entity to dispose of assets to meet liquidity requirements.

\section{IAS 32 Financial Instruments: Disclosure and Presentation-Case Study OF THE RESERVE BANK OF NEW ZEALAND ${ }^{9}$}

\section{A. Introduction}

This section discusses issues for central banks in applying IAS 32-Financial Instruments: Disclosure and Presentation (IAS 32). ${ }^{10}$ In addition, the section considers the broader issue of appropriate financial instrument risk disclosures for central banks, including:

\footnotetext{
${ }^{9}$ Prepared by Richard Perry.

${ }^{10}$ This includes disclosures previously specified in IAS 39.
} 
- the importance of financial instrument risk disclosures, including an overview of key risks associated with financial instruments;

- qualitative disclosures, including disclosure of risk management policies and the nature and extent of activities;

- quantitative risk disclosures, including interest rate risk, foreign currency risk, credit risk, liquidity risk, and fair values; and

- offsetting financial assets and liabilities in balance sheet presentation.

The RBNZ's 2002-2003 financial statements, included as Appendix II, are used as a case study for various disclosures. However, it should be noted that:

- The RBNZ's financial statements are prepared in accordance with the requirements of New Zealand accounting standards. New Zealand accounting standards and disclosures reflect requirements considered appropriate to the New Zealand legal and economic situation and are not necessarily the same as the requirements of IAS.

- In addition, the RBNZ's financial statements contain disclosure requirements required under International Financial Reporting Standards. However, the financial statements have not been prepared in accordance with the measurement and recognition requirements of IFRS. Therefore, the disclosures, which are specific to those measurement and recognition requirements, have not been made.

\section{B. Importance of Financial Instrument Risk Disclosures}

During the early to mid-1990s, there was increasing recognition of the need for organizations to provide comprehensive information on the nature and extent of their exposure to financial risks. This was in part due to the dynamic nature of financial markets and the growing use and development of more complex financial instruments such as derivative financial instruments. An entity can substantially change its financial risks very quickly by entering into financial transactions including derivative instruments. For example, derivatives may be used to modify a particular financial risk, to reduce or even eliminate exposure to it. Alternatively, derivatives may be used as speculative tools to multiply the effects of changes in interest rates, foreign currency rates, or security prices. ${ }^{11}$

\footnotetext{
${ }^{11}$ It is noted that central banks do not typically enter into derivative instruments primarily for speculative purposes. Central bank objectives tend to be more policy-oriented rather than profit-oriented, and derivative instruments are generally used to assist in the risk management of financial assets and liabilities held for policy purposes.
} 
In addition, there was an increase in the demand for information on financial risks and risk management systems because of financial market crises (such as the collapse of Barings Bank and the Asian financial crisis). A number of these financial market crises arose from the combination of poor risk management and complex financial instruments, combined with low or ineffective levels of disclosure. This raised the need for published information on the nature and extent of financial risk that an organization faced and the way in which these risks were managed and mitigated.

As previously discussed, relevant, reliable, and timely financial information is of crucial importance to the efficient operation of modern capital markets. ${ }^{12}$ Information uncertainties can increase the cost of capital to an entity. Accounting standard setters have sought to reduce information uncertainties arising from involvement in financial instruments by developing specific standards (including IAS 32) that detail disclosure requirements for financial instruments. The importance of disclosure concerning financial instruments is reinforced by other international organizations. For example, a 1999 survey of trading and derivative disclosures published by the Basel Committee and International Organization of Securities Commissions (IOSCO). These two groups considered transparency of banks' and securities firms' activities and risks to be a key element of an effectively supervised financial system as follows:

Transparency, based on meaningful public disclosure, plays an important role in reinforcing the efforts of supervisors in encouraging sound risk management practices and fostering financial market stability. ${ }^{13}$

This report suggested that financial institutions should:

- Provide financial statement users with a clear picture of their trading and derivatives activities. They should disclose meaningful summary information, both qualitative and quantitative, on the scope and nature of their trading and derivatives activities and illustrate how these activities contribute to their earnings profile. They should also disclose information on the major risks associated with their trading and derivatives activities and their performance in managing these risks.

- Disclose information produced by their internal risk measurement and management systems on their risk exposures and their actual performance in managing these exposures. Linking public disclosure to internal risk management processes helps ensure that disclosure keeps pace with innovations in risk measurement and management techniques.

\footnotetext{
12 See Section III, “Applying IAS 1 and IAS 30 to Central Bank Reporting.”

${ }^{13}$ See "Recommendations for public disclosure of trading and derivatives activities of banks and securities firms," consultative paper issued jointly by the Basel Committee on Banking Supervision and Technical Committee of IOSCO, February 1999, www.iosco.org.
} 
While these recommendations are for derivative instrument disclosures, they are equally relevant to disclosures concerning financial instruments in general.

The importance of disclosures concerning financial instruments is reflected in the requirements of IAS 32. The objective of IAS 32 is to enhance financial statement users' understanding of the significance of financial instruments to an entity's financial position, performance, and cash flows. IAS 32 requires the disclosure of information about the factors that affect the timing and certainty of an entity's future cash flows relating to financial instruments and the accounting policies applied to those instruments.

In particular, IAS 32 requires disclosure of information about the nature and extent of an entity's use of financial instruments, the business purpose they serve, the risks associated with them, and management policies for controlling those risks. This assists users to understand the risks associated with financial instruments, including market risk, credit risk, and liquidity risk. Each of these risk types is defined below:

- Market risk. IAS 32 identifies three types of market risk, as follows:

- Currency risk is the risk that the value of a financial instrument will fluctuate because of changes in foreign exchange rates.

- Fair value interest rate risk is the risk that the value of a financial instrument will fluctuate because of changes in market interest rates.

- Price risk is the risk that the value of a financial instrument will fluctuate as a result of changes in market prices, whether those changes are caused by factors specific to the individual instrument or its issuer or factors affecting all instruments traded in the market.

- Credit risk. The risk that one party to a financial instrument will fail to discharge an obligation and cause the other party to incur a financial loss.

- Liquidity risk. The risk that an entity will encounter difficulty in raising funds to meet commitments associated with financial instruments. Liquidity risk may result from an inability to sell a financial asset quickly at close to its fair value.

- Cash flow interest rate risk. The risk that the future cash flows of a financial instrument will fluctuate because of changes in market interest rates.

Financial statement users can generally obtain the information they require on the risks arising from involvement in financial instruments through two types of disclosure:

Narrative or qualitative disclosures. These explain the risks the entity is exposed to; how the entity evaluates these risks; how the entity uses financial instruments to manage financial risks and major policies adopted to limit and control risk. This information will 
- Quantitative disclosures. This information is used for evaluating the extent to which the entity is exposed to market risk, credit risk, liquidity risk, or cash flow interest rate risk.

Central banks will typically hold significant volumes of financial instruments as part of their operations. Hence, central banks can face significant financial risks in their own operations. The risks typically include: foreign currency risk from the management of foreign reserves; interest rate risk on foreign and local currency assets and liabilities; liquidity risk associated with the management of foreign reserves; and credit risk on local and foreign currency assets. In addition, central banks face risk associated with general operations (operational risk) and the risk of damage to the central bank's credibility and reputation (reputation risk).

Users of central bank financial statements will be concerned with the extent to which the central bank is using financial instruments in appropriate circumstances and that the central bank is appropriately managing the risks that arise from involvement in financial instruments. Disclosures that demonstrate the central bank is appropriately managing financial risks are important because the central bank is managing public resources. The central bank can use these disclosures to demonstrate that appropriate care and responsibility are being taken to manage these public resources.

Transparent qualitative and quantitative disclosure can demonstrate that the central bank is aware of the risks associated with financial instruments and that these risks are being appropriately managed. Even if the central bank deliberately chooses not to manage specific risks arising from involvement in financial instruments, the disclosure of this information may enhance the credibility of the central bank. For example, a central bank could explain the reasons why exposure to foreign currency risk is not managed in order to avoid external criticism in the event the central bank incurs large unrealized foreign currency gains or losses.

In addition, many central banks have a responsibility for supervision of commercial banks within their countries including the regulation of commercial bank disclosures. This provides central banks with an opportunity to promote best practice in disclosure and transparency concerning financial instruments in areas they have in common with commercial banks.

Similarly, the RBNZ is responsible for the supervision of commercial banks in New Zealand. The New Zealand approach to supervision is based on public disclosures of information. The failure of traditional supervisory approaches to prevent substantial bank failures and the risk of moral hazard have caused the RBNZ to adopt a public disclosure regime for commercial banks. As a result, commercial banks have, in some situations, looked to the RBNZ practices to gain illustrations of best-practice disclosure. Therefore, the RBNZ has committed to preparing its financial statements according to best-practice accounting and disclosure requirements as applicable to a central bank. In pursuing this objective, the RBNZ attempts to set an example, where appropriate, for commercial banks to follow. 


\section{Narrative and Qualitative Disclosures}

Qualitative disclosures provide management with an opportunity to explain the risk management objectives of the central bank, and how these objectives fit into the overall central bank objectives. This can include information on the nature and extent of involvement in financial instruments, risk management policies in general, specific risk management policies for each of the major risk categories (i.e., the policies used for managing interest rate risk, credit risk, foreign currency risk and liquidity risk), and the accounting policies for financial instruments.

\section{Nature and extent of activities}

IAS 32 requires disclosure of information about the nature and extent of financial instruments, including significant terms and conditions that may affect the amount, timing, and certainty of future cash flows. Information on the nature and extent of financial instruments allows the financial statement users to understand the central bank's business reasons for using financial instruments. For example, the central bank may explain that financial instruments are used for specific policy purposes such as the implementation of monetary policy. Alternatively, the central bank may use derivative financial instruments, such as forward foreign exchange contacts, as a tool to reduce exposure to foreign currency risk. Disclosure of this type of information can assist financial statement users to understand the reasons why the central bank uses financial instruments and, provide a better understanding of the overall risk-taking philosophy of the central bank.

The approach taken by the RBNZ is to present this information as the first note to the financial statements. The disclosures provide specific information concerning the following:

- The RBNZ's foreign currency activities (note 1(a)) provide an overview of financial instruments arising from the RBNZ's management of New Zealand's foreign reserve portfolio, the funding for these financial instruments and the management of these financial instruments including the risk-taking philosophy used in foreign reserves management.

- Significant events that affected on the RBNZ's involvement in different types of foreign currency financial instruments (note 1(b)).

- An overview of the RBNZ's involvement in derivative instruments (note 1(c)).

- An overview of the involvement in a securities lending program (note $1(\mathrm{~d})$ ) including the amount lent out under the program at balance date. ${ }^{14}$

\footnotetext{
${ }^{14}$ Under the securities lending program, the RBNZ contracts an external agent to lend out a portion of the RBNZ's foreign currency securities. The agent will lend these securities to financial market counterparties in order to generate income. This lending arrangement is completed in accordance with predefined terms and
} 
- An outline of the legislative provision that permits the minister of finance to direct the RBNZ to intervene in the foreign exchange market (note 1(e)) and the extent of such directed intervention.

- Disclosure of legal restrictions on assets (note 1(f)). The purpose of this disclosure is to allow readers to determine whether any assets that are recorded in the balance sheet have legal restrictions against them. For example, a central bank may have assets that have been pledged as security in repurchase transactions. ${ }^{15}$ This disclosure is also required by IAS 30 (para. 60).

- Discussion of the RBNZ's involvement in financial instruments arising from local activities including monetary policy implementation (note 1(f)).

\section{Risk management policies}

IAS 32 requires an entity to describe its financial risk management objectives and policies including its policy for hedging each main type of forecast transaction for which hedge accounting is used. This discussion may include information on the principal internal control procedures in place such as the existence of a centralized risk management committee, a summary of any involvement in new financial instruments, the risks associated with new financial instruments, and a description of any hedging policies. For example, a central bank may have specifically authorized procedures and policies governing the use of financial instruments. Summary disclosure of this information can be used to demonstrate that appropriate risk management processes and controls exist for each of the major financial risks that the central bank is exposed to. This disclosure demonstrates that the central bank has an appropriate risk management structure. This information is important in central bank circumstances because the central bank is managing public resources and can demonstrate that appropriate systems are in place to minimize financial risks. It is suggested that central banks specifically discuss the following:

Risks and management controls. This includes an overview of the key aspects of the organizational structure used in the risk management and control process. The discussion may explain the existence of a centralized risk management committee and whether separate divisions of the central bank are responsible for measuring and monitoring central bank financial risk. The disclosure can include a description of each major risk the central bank is exposed to, how these risks arise, and the methods used to manage and measure the risks.

conditions designed to minimize the risks of the arrangements. The external agent and the RBNZ share the income earned through this program.

${ }^{15}$ Under a repurchase transaction, the central bank may borrow cash and pledge financial securities as security to the borrowing arrangement. The typical accounting treatment results in the financial securities that have been pledged as security continuing to be recorded as assets in the central bank's balance sheet. 
The RBNZ provides an overview of its risk management structure in note 16 . Notes 18 to 23 then discuss the background to how the risks arise for operational risk, credit risk, interest rate risk, foreign currency risk, and liquidity risk. The techniques used to manage each of these risks are specifically considered, including the major internal control processes.

Credit risk is the risk of loss arising from counterparty default. Qualitative credit risk disclosures can summarize the central bank policies for identifying, measuring, and managing credit risk. The discussion might address the structure of the credit/loan review function (i.e., how does the central bank assess the creditworthiness of their counterparties), internal controls, risk limits, and limit monitoring. Risk limits and limit monitoring refer to the risk management process of limiting the total assets held with any single counterparty. The process of limiting the total assets held with a single counterparty is effective only if it is supported by regular reporting of actual exposures compared to limits.

The qualitative credit risk disclosures should also discuss any mechanisms used to reduce credit exposure, including the use of collateral and any netting agreements. Central banks may require collateral before they are prepared to provide funding in situations such as the implementation of domestic monetary policy implementation.

The RBNZ credit risk management approach is outlined in note 18(a). This provides an overview of the credit risk management framework and limit framework. The analysis is extended to include a discussion of the collateral that is accepted by the RBNZ in the operation of New Zealand's real time gross settlement system.

Interest rate risk is the risk that the value of a financial instrument will fluctuate because of changes in market interest rates. This reflects that changes in the level of interest rates will change the present value of financial instruments. Where financial instruments are accounted for on the basis of market values, changes in value will be recognized in the income statement of the central bank. Disclosure can summarize the policies used for measuring and managing interest rate risk and how the central bank reviews its effectiveness in managing interest rate risk. This allows the financial statement users to know that the central bank is aware of exposure to interest rate risk and that appropriate steps have been taken to manage exposure to changes in interest rates.

The RBNZ discloses the policies used for measuring and managing interest rate risk in notes 19 and 21. This risk arises from the RBNZ's management of foreign reserves. The disclosure includes an overview of the "Value at Risk" (VaR) model that is used to manage the RBNZ's exposure to interest rate risk and foreign currency risk. VaR is a statistical model that estimates the potential daily loss from movements in interest rates and foreign currencies in normal market conditions. The metric is calculated by statistically modeling historical interest rate movements and using these movements to predict exposure to future losses within a specific probability range. These types of VaR model are often used by commercial banks to manage commercial bank interest rate and foreign currency risk. 
The RBNZ disclosure includes the VaR model parameters and major model assumptions. This information is provided to facilitate an understanding of the effectiveness of the RBNZ model in managing interest rate risk.

In addition, information is provided on the existence and level of stop-loss limits used to limit losses that may arise from departures from the risk neutral position.

Foreign currency risk is the risk of loss arising from changes in the level of foreign currency rates. The narrative disclosure for foreign currency risk can explain the extent to which the central bank has exposure to foreign currency risk and whether any methods are used to manage and monitor foreign currency risk.

The RBNZ qualitative disclosure on foreign currency risk in note 20 explains how the RBNZ is only exposed to foreign currency risk arising from trading positions undertaken by specialist staff. Foreign currency risk is managed by way of VaR limits and stop-loss limits for the combined market risk, as explained in note 21 . The hedging practice in respect of foreign currency exposure arising from domestic operations is described.

Liquidity risk is the risk that an entity will encounter difficulties in raising funds to meet obligations as they fall due. Liquidity risk may result from an inability to sell an asset quickly at close to its fair value. Disclosure can include how liquidity risk arises and practices undertaken to manage liquidity risk.

The RBNZ management of liquidity risk of foreign currency assets is explained in note 22 . This includes the use of liquid asset ratios and limits on the minimum and maximum proportion of reserves that may be held in any one currency and the monitoring of these limits. Further information is provided on additional credit arrangements including credit lines. Given the nature of the New Zealand central bank operations, the RBNZ is not subject to local currency liquidity risk.

\section{Accounting policies}

For each class of financial asset and liability, IAS 32 requires disclosure of the accounting policies. This includes valuation methods adopted, the criteria used for recognizing gains and losses in the income statement, and whether regular way purchases and sales of financial assets are accounted for at trade date or settlement date.

Disclosures about accounting policies assist users to understand any important distinctions that exist in the accounting treatment of various types of financial instruments. IAS permit a variety of methods to account for financial instruments. ${ }^{16}$ The accounting policies used for

\footnotetext{
${ }^{16}$ This is further discussed in Appendix III concerning IAS 39: Recognition and Measurement of Financial Instruments.
} 
financial instruments will impact on how gains and losses are recognized in the income statement. For example, a mark-to-market method of accounting, held for trading assets, will immediately recognize any changes in the market value of financial assets and liabilities in the income statement. Conversely, historic cost accounting will recognize only interest paid and received on financial instruments in the income statement. Where financial instruments are marked to market, the disclosure should explain the basis used for calculating market values, such as use of external market prices or internal valuation models. Because the accounting practices for derivatives are not always consistent across countries or between institutions, it is particularly important that the central bank describe the accounting treatment of derivative instruments.

IAS 32 requires detailed disclosure of the methods used to determine fair values of financial instruments. Where fair value is the basis for measurement and recognition, this information can be included as part of the accounting policies. The disclosure requirements for determining fair values include the methods and significant assumptions, whether fair values are determined directly, by reference to published market prices, or estimated using a valuation technique.

The RBNZ provides detailed accounting policies for all significant categories of financial instruments. This detail includes information on the balance sheet presentation, income recognition, valuation basis, and the methods used to determine the value of financial instruments measured and recognized at fair value. Expanded information on accounting policies for financial instruments is seen as an opportunity to promote transparency of disclosures of accounting policies for commercial banks. Accounting policies for financial instruments will have a significant impact on the presentation and measurement of assets and liabilities and commercial bank profitability.

\section{Fair value disclosures}

Fair value information provides a neutral basis for assessing management stewardship by indicating the effects of its decisions to buy, sell, or hold financial assets and to incur, maintain or discharge financial liabilities. Fair value information permits comparisons of financial instruments that have the same economic characteristics regardless of why they are held or acquired. The qualitative disclosures of fair values will discuss the methods and significant assumptions used to determine the fair value of financial instruments, including whether fair values are determined directly, by reference to published market prices, or estimated using a valuation technique. In the case of instrument categories for which there are no external market prices, the discussion should highlight the methods and assumptions used to estimate market value.

A specific fair value issue unique to central bank circumstances is the method used to assess the fair value of currency in circulation. This is typically calculated as the face value of currency issued. 
The RBNZ discusses the methods used to calculate the fair value disclosures for each class of financial instrument in the accounting policies where the accounting measurement basis is fair value and in note 14 for the other financial instruments. This includes discussion of relevant valuation methods and reasons why book value is considered to approximate fair value for certain instruments.

\section{Other risks}

Legal, operational, and reputation risk pose significant concerns to central banks, but accurate measurement of these risks is often difficult. However, central banks can help financial statement users understand these risks by providing information on the nature of the risks and describing how they relate to the central bank's activities.

The RBNZ discusses operational risk in note 17. The discussion includes an overview of the main techniques used to manage operational risk. However, there is limited discussion of the other risk types including the management of reputation risk.

\section{Quantitative Disclosures for Financial Instruments}

Quantitative information provides users with an understanding of the degree of risk exposure within each major risk category. IAS 32 requires certain quantitative information for interest rate risk, credit risk, and fair values. IAS 30 requires quantitative information for liquidity risk and foreign currency risk. This section provides an overview of the quantitative disclosures for the requirements of IAS 30 and IAS 32, excluding liquidity risk. The requirements for liquidity risk disclosures have been outlined in an earlier section. ${ }^{17}$

\section{Interest rate risk}

IAS 32 requires disclosure of information concerning the entity's exposure to interest rate risk for each class of financial asset and financial liability. This allows financial statement users to understand the economic impact for the entity owing to changes in interest rates.

IAS 32 expects the disclosure to include information on the maturity or interest rate repricing dates for various financial instruments and information on effective interest rates. Interest rate repricing dates are the dates at which the interest rate on variable financial assets or liabilities will change. The basic idea is that the present value of financial assets and liabilities will change when there is a change in interest rates. An increase in the level of interest rates will result in a decrease in the present value of financial assets and liabilities, and vice versa. The magnitude of this change will generally depend on the remaining time to maturity of the financial instrument. All things being equal, financial instruments with longer terms to maturity will be subject to greater present value changes because of a change in

${ }^{17}$ See Section III, “Applying IAS 1 and IAS 30 to Central Bank Reporting." 
interest rates. This logic evolves from the "time value of money" concept that underpins modern financial markets.

For banks, the IAS 32 disclosure is typically by way of an interest rate repricing table. Assets and liabilities are grouped into various periods based on the maturity or interest rate repricing period. Interest rate risk increases if there is a mismatch between the repricing of financial assets and liabilities. A mismatch arises where the maturity or repricing dates for financial assets and liabilities are different. Where a mismatch exists, the present value of the assets and liabilities will change by different amounts when interest rates change.

For example, consider an asset with a remaining maturity of five years and a liability with a maturity of one year. If interest rates change, the value of the asset will change by a different amount to the value of the liability. The existence of this situation could be highlighted in the following table:

\begin{tabular}{|c|c|c|c|c|c|}
\hline Maturity & 1 year & 2 years & 3 years & 4 years & 5 years \\
\hline Assets & & & & & 100 \\
\hline Liabilities & 100 & & & & \\
\hline $\begin{array}{c}\text { Gap (Assets less } \\
\text { Liabilities) }\end{array}$ & (100) & & & & 10 \\
\hline
\end{tabular}

A repricing schedule increases the understanding of interest rate risk because it compares the maturity or repricing of assets and liabilities over future periods. This allows users to identify any significant "gaps" in the repricing of financial assets and liabilities. Hence, the financial statement user may obtain an understanding of how much the entity would gain or lose because of a change in interest rates.

The RBNZ provides a comprehensive interest rate repricing schedule, using the asset and liability categories presented on the face of the balance sheet (note 19). This has been extended to provide repricing gap information by currency to further enhance understanding of potential exposure to interest rate risk within specific currencies.

The balance sheet asset and liability categories have also been used to present the quantitative risk disclosures for credit risk and foreign currency risk. The approach of using the balance sheet asset and liability categories is intended to provide users with a comprehensive presentation of the RBNZ's assets and liabilities and the risk profile for each category of assets and liabilities. This approach allows the financial statement user to understand the reasons why the central bank holds different assets and liabilities and the extent of the risk associated with each category of asset and liability.

As discussed in the section on qualitative disclosures, information can be provided on the exposure to interest rate risk as measured by VaR. VaR models predict the loss that would arise on financial assets because of changes in the level of interest rates or foreign currencies. 
Note 21 provides the RBNZ VaR measures. This information includes the year-end VaR position, internal limits, peak exposure, average exposure, and the lowest exposure. The peak exposure is the maximum $\mathrm{VaR}$ position that has arisen during the financial year. Information on the peak, average, and low exposure allows users to understand the extent to which risk limits have been utilized during the period.

\section{Credit risk}

The main credit risk disclosures required by IAS 32 include the amount that best represents the maximum credit risk exposure and any significant concentrations of credit risk. The disclosures of significant concentrations of credit risk are similar to the requirements of IAS 30 (para. 40) to disclose significant concentrations of assets and liabilities by geography, customer, industry, or other concentration. From a credit risk perspective, this information assists users to assess the degree of credit exposure a central bank may have to any specific sector. This is important to understand the risks the central bank may face if a particular region/country or industry experiences financial difficulties and was subsequently unable to meet debt obligations. In addition, these disclosures can be used to demonstrate the overall credit quality of the central bank asset portfolio.

The RBNZ example is provided in note 18 (b) which provides credit exposure by industry and geography. Additional quantitative credit exposure information is provided as follows:

- Credit exposure by credit rating (note 18 (c)). This analysis of financial assets by the credit rating of the issuers allows users to assess the overall credit quality of the RBNZ's financial assets.

- Credit exposure by counterparty (note 18 (d)). This includes the number of end-ofyear and peak credit exposure to individual counterparties in excess of 10 percent of the RBNZ's equity. This allows users to assess credit exposure to individual counterparties and obtain an understanding of any large credit exposures. This is more important in a commercial banking environment where users can understand the impact that a default of a single large counterparty would have on the commercial bank's equity.

\section{Foreign currency risk}

IAS 32 does not specifically require disclosure on information concerning foreign currency risk. IAS 30 has a requirement to disclose the amount of significant net foreign currency exposures to provide information regarding the degree of foreign currency risk the entity faces. A significant net foreign currency concentration exposes an entity to the risk arising from changes in foreign currency rates.

The RBNZ provides this information in note 20, including the amount of foreign currency held in each class of foreign currency financial asset and liability. 


\section{Fair values}

Where assets and liabilities are not reported at fair value on the face of the balance sheet, IAS 32 requires disclosure of their fair value in the notes to the accounts. Where fair values are determined by a valuation technique not supported by observable market prices or rates and changing any valuation assumption would result in a significantly different fair value, disclosure is required including the effect on the fair value of a range of reasonably possible alternative assumptions. For example, this may arise in circumstances where a central bank has a significant holding of financial assets that are not actively traded or where the central bank is essentially the only active price maker. In this circumstance, the range of fair values possible under the different assumptions is required.

The RBNZ fair values are presented in note 14 .

\section{Concentrations of funding}

IAS 30 requires disclosure of any significant concentrations of liabilities. This provides an indication of the potential risks inherent in a bank's funding.

The RBNZ discloses this information in note 15.

\section{E. Collateral}

An entity's policies for and extent to which financial assets are pledged or received as collateral can provide important information on the extent to which financial assets may be encumbered or available for other purposes.

IAS 32 requires disclosure of the amount of financial assets pledged as collateral for liabilities or contingent liabilities and any material terms and conditions relating to assets pledged as collateral. Where an entity has accepted collateral that it is permitted to sell or repledge, it shall disclose the fair value of the collateral accepted, sold, and any material terms and conditions associated with its use of this collateral.

Central banks that have pledged financial assets as collateral do not have those assets available for other purposes. For example, in the situation where funds were needed for foreign exchange intervention, any assets pledged as collateral under repurchase transactions would not be available to fund intervention.

The RBNZ provides information on the collateral pledged and received under interest rate swaps, repurchase and reverse repurchase agreements in note 1(f).

\section{F. Offsetting Financial Assets and Liabilities}

Readers generally expect financial assets and liabilities to be presented on a gross basis in the balance sheet. This means that assets and liabilities should not be netted against each other 
for reporting purposes. This approach ensures that the balance sheet presents all the obligations and resources of the entity — netting obligations may understate actual assets and liabilities and misrepresent the underlying economic position.

However, offsetting assets and liabilities is permitted under IAS 32 when the entity has a legally enforceable right to set off the recognized amounts and the entity intends to settle the obligations on a net basis. A legal right of set-off will usually arise under either:

- contract law_where parties to the agreement explicitly acknowledge a right to set off.

- common law - through the traditional acceptance of a right of set off and the practice of doing so.

To be recognized in the balance sheet, a legal right of set-off should be enforceable in a liquidation or bankruptcy.

The RBNZ typically follows the strict practice of not setting off assets and liabilities in the balance sheet.

\section{G. Other IAS 32 Disclosure Requirements}

IAS 32 has several other disclosure requirements. The RBNZ is not currently affected by the events or activities that give rise to disclosure under these requirements. Therefore, the RBNZ financial statements do not provide examples of these other IAS 32 disclosures. These disclosures arise from the following:

- Debt/equity classification of financial instruments (IAS 32 paragraphs 15, 26, 28, 33, 35). IAS 32 sets out the classification and disclosure of financial instruments as financial liabilities, financial assets or equity instruments. This includes guidance on how to separately classify and disclose financial instruments in these categories and the treatment of payments arising from the instruments as dividends or interest.

- Derecognition (IAS 32 para. 94 (a)). Disclosure is required where financial assets have been derecognized when the entity has transferred all or part of a financial asset.

- Compound financial instruments with multiple embedded derivatives (IAS 32 para. 94(d)). If an entity has issued an instrument that contains both a liability and an equity component and the instrument has embedded derivative features whose values are interdependent, IAS 32 requires disclosure of these features.

- Disclosure from the application of IAS 39 Financial Instruments: Recognition and Measurement. The disclosure requirements that were previously included in IAS 39 are now part of IAS 32. These disclosure requirements include: 
- IAS 32 para. 58. Information on hedge accounting under IAS 39 including a description of the hedge, the financial instruments designated as hedging instruments, and the nature of risks being hedged.

- IAS 32 para. 59. Gains or losses on hedging instruments recognized in equity including the amounts recognized in equity for the period and amounts removed from equity.

- IAS 32 para. 94(e) and 94(f). Information on the carrying amounts of financial assets and liabilities that were designated as held for trading and as financial assets a financial liability at fair value through profit or loss.

- IAS 32 para. 94(g). The reasons for any reclassification of financial assets as one measured at cost rather than fair value.

- IAS 32 para. 94(h). Material items of income, expense, and gains and losses resulting from financial assets and financial liabilities, whether included in profit or loss or as a separate component of equity.

- Impairment (IAS 32 para. 94(i)). The nature and amount of any impairment loss recognized in profit or loss for a financial asset shall be disclosed.

- Defaults and breaches (IAS 32 para. 94(j)). Information with respect to any defaults of principal or interest, and any other breach during the period of the loan.

\section{H. Summary}

This section has discussed issues for central banks in applying IAS 32. Central banks have an important role in disclosures of financial instruments, since central banks will typically hold significant volumes of financial instruments as part of their operations. Hence, users of central bank financial statements will be concerned with the extent to which the central bank is using financial instruments in appropriate circumstances and that the central banks are appropriately managing the risks that arise from involvement in financial instruments.

Transparent qualitative and quantitative disclosure can demonstrate that the central bank is aware of the risks associated with financial instruments and that these risks are being appropriately managed.

In addition, many central banks have a responsibility for supervision of commercial banks within their countries, including the regulation of commercial bank disclosures. This provides central banks with an opportunity to promote best practice in disclosure concerning financial instruments. 


\section{IAS 7-CASH FLOW STATEMENTS ${ }^{18}$}

\section{A. Introduction}

This section outlines some of the issues to be considered in the preparation of the statement of cash flows. IAS 7: Cash Flow Statements (IAS 7) requires the presentation of the cash flow statement as an integral part of an entity's financial statements. Some of the issues that can arise for a central bank include:

- the purpose of the cash flow statement;

- how cash should be defined;

- defining investing and financing cash flows;

- $\quad$ presentation of gross or net cash flows; and

- the direct or indirect method of presenting operating activities.

\section{B. Purpose of the Cash Flow Statement}

The purpose of the cash flow statement is to help users of financial statements assess an entity's ability to generate cash flows and the needs of the entity to utilize those cash flows. The cash flow statement is based on the concept that the purpose of a business is to make a profit, realize it in cash, and do this repeatedly. The entity's cash flows are required to be classified according to the activity that gave rise to them.

- Operating activities. The principal revenue-producing activities of the entity and other activities that are not investing or financing activities.

- Investing activities. The acquisition and disposal of long-term assets and other investments not included in cash equivalents.

- Financing activities. Activities that result in changes in the size and composition of the equity capital and borrowings of the entity.

These classifications can be thought of as an entity raises money (financing activities), invests this money in long-term assets (investing activities), and obtains income and expenses from those assets (operating activities). The cash flow statement shows how the entity generates cash flows and presents information on changes in the entity's investing and financing structure.

${ }^{18}$ Prepared by Richard Perry. 
Owing to the definition of cash, a statement of cash flows does not always represent the actual liquidity of a central bank. Moreover, a central bank will often be responsible for issuing circulating currency and managing the liquidity of the domestic banking system. Some commentators consider that these factors reduce the information value of the cash flow statement in the central bank's circumstances. For example, the Reserve Bank of Australia expresses presentation concerns in the opening introduction to their statement of cash flows:

The following cash flow statement appears as a matter of record to meet the requirements of AAS28; in the RBA's view, it does not shed any additional light on the RBA's financial results. For the purpose of this statement, cash includes the notes and coin held at the Reserve Bank and overnight settlement system account balances with other banks. ${ }^{19}$

The Reserve Bank of New Zealand (RBNZ) experienced similar concerns that resulted in a substantial review of the RBNZ's cash flow statement to improve the presentation and to ensure the cash flow statement provided an improved indicator of the RBNZ's liquidity.

In central bank circumstances, the RBNZ view is that the statement of cash flows and related notes to the accounts can be used to provide information on the:

- Extent to which operating income was generated in cash and the extent to which reported profits are available to distribute as dividends.

- Cash impact of the major changes in the RBNZ's balance sheet structure during the financial year by presenting the net cash changes in the major balance sheet categories. This approach is intended to assist the financial statement users understand how cash has been generated and applied to change the RBNZ's balance sheet structure during the financial year.

- The liquidity of the RBNZ. This information was only possible following a revision in the RBNZ's definition of "cash."

The cash flow statement is likely to be most important in supporting the distribution of central bank profits. Central banks are often confronted with having large unrealized gains that should not be distributed as part of the central bank dividend. The distribution of unrealized gains may have monetary policy implications because the central bank may not hold the liquidity to fund the distribution to the government's budget. This would result in a monetary emission to the government.

A properly constructed central bank cash flow statement will clearly present cash flows from operating activities, which demonstrates the extent to which the central bank's current year

${ }^{19}$ See note 19 of the Reserve Bank of Australia's 2003 Financial Statements, www.rba.gov.au. 
profit has been converted into cash. This presentation will provide a mechanism to support any decisions not to distribute unrealized profits, as it will illustrate the central bank's cash position, and where profits have yet been realized as cash. Equally, if the central bank does distribute unrealized gains, these unrealized gains will need to be funded by selling assets (investing activities), issuing currency or borrowing from third parties (financing activities). The cash flow statement will clearly demonstrate how a central bank has funded any distribution of profits.

\section{Definition of Cash}

Cash is generally defined to include cash on hand, demand deposits, and highly liquid investments that are readily convertible cash and which are subject to an insignificant risk of changes in value. However, due to the high liquidity of most central bank assets, a wide definition of cash could lead to a high proportion of the central bank's assets being considered cash.

This would mean that the disclosure of cash flows in the investing (how cash has been applied) and financing (how cash has been generated) sections would be contained entirely in the opening and closing cash positions. While this may be a better indicator of a central bank's liquidity it does reduces the ability of the cash flow statement to accurately provide information on how cash is generated and applied.

The RBNZ approach has been to consider cash as those financial instruments that are highly liquid and are used in the day-to-day cash management of the central bank. This definition has included the highly liquid foreign reserve assets of the RBNZ and local currency financial assets that arise from the RBNZ's management of the New Zealand Government bank account held with the RBNZ.

The definition of cash ensures that the RBNZ's cash balances provide an indicator of the actual liquidity of the RBNZ. Previously, the RBNZ defined cash in a way that resulted in a negative cash balance being reported. This approach was not considered to provide a fair presentation of the actual liquidity of the RBNZ.

\section{Defining Investing and Financing Cash Flows}

IAS 7 suggest presentations of cash flows according to the definitions of operating activities, investing activities, and financing activities. In a central bank, these definitions could be applied as follows:

- Operating activities. This category includes the main cash revenue and expense flows such as paying and receiving of interest, fee income, and operating expenses. Remaining activities that have not been classified as investing or financing are usually included as operating activities. 
- Investing activities. These comprise investments from monetary policy and foreign reserves operations, any other investment of circulating currency, and the sale and purchase of fixed assets.

- Financing activities. This includes issue and repayment of circulating currency, loans used to fund long-term borrowings (such as the funding for holdings of foreign reserves or funding from the IMF), and disbursement of the annual dividend.

The effect of exchange rate changes on cash and cash equivalents held or due in a foreign currency is reported in the cash flow statement in order to reconcile cash at the beginning and the end of the period. This amount is presented separately and includes the differences, if any, had those cash flows been reported at end-of-period exchange rates.

\section{E. Presentation of Gross or Net Cash Flows}

Cash flow statements are generally expected to present gross flows of cash. However, cash flows may be reported net when they are on behalf of customers and reflect the activities of customers rather than those of the entity. In addition, cash receipts and payments may be reported net for items in which the turnover is quick, the amounts are large, and the maturities are short.

It is generally accepted that net cash flows are appropriate when the cash movements arise through external factors such as a client depositing funds with a retail financial institution. However, gross cash flows may be more useful to provide a scale of the risks facing the entity either in terms of cash handling (i.e., the business has handled this volume of cash) or in trading activities (i.e., the volume with which a portfolio is bought and sold).

\section{F. Direct and Indirect Methods of Preparation}

IAS 7 suggests that entities should report cash flows from operating activities using either the direct or the indirect method. Under the direct method, major classes of gross cash receipts and gross cash payments are disclosed, while the indirect method presents the net profit or loss and adjustments for the effects of noncash transactions including balance date accruals and unrealized gains and losses.

Entities are encouraged to use the direct method because this may provide information useful in estimating future cash flows since it adds new information unavailable from the balance sheet and income statement. In addition, the direct method is considered to best reflect the gross inflows and outflows of cash from operating activities.

\section{G. Summary}

A cash flow statement can provide useful information on central bank activities that is not available in other sections of the financial statements. The cash flow statement can be used to assist the financial statement users in understanding how cash has been generated and applied to change the central bank's balance sheet structure during the financial year and provide an 
indication of the liquidity of the central bank. Moreover, the cash flow statement provides a basis for understanding the extent to which the central bank profit has been generated in cash and how distributions to government are funded. 


\section{SUMMARY OF IAS DISCLOSURE REQUIREMENTS ${ }^{20}$}

\section{A. Introduction}

This section provides a summary of the detailed IAS disclosure requirements for:

- IAS 1-Presentation of Financial Statements (IAS 1);

- IAS 2-Inventories (IAS 2);

- IAS 7-Cash Flow Statements (IAS 7);

- IAS 8-Accounting Policies, Changes in Accounting Estimates and Errors (IAS 8);

- IAS 10-Events after Balance Date (IAS 10);

- IAS 16-Property, Plant and Equipment (IAS 16);

- IAS 17-Leases (IAS 17);

- IAS 18-Revenue (IAS 18);

- IAS 21-The Effects of Changes in Foreign Exchange Rates (IAS 21);

- IAS 24-Related Party Disclosures (IAS 24);

- IAS 30-Disclosures in the Financial Statements of Banks and Similar Financial Institutions (IAS 30);

- IAS 32-Financial Instruments: Disclosure and Presentation (IAS 32);

- IAS 37-Provisions, Contingent Liabilities and Contingent Assets (IAS 37); and

- IAS 39-Financial Instruments: Recognition and Measurement (IAS 39)-effective 1 January 2001.

This section has been designed to assist in the preparation of central bank financial statements in accordance with the requirements of these standards and sets out the disclosure requirements of each standard that is effective for periods beginning on or after January 1, 2005. The section has been set out in the form of a "check-list" to facilitate the review of central bank financial statements against the disclosures required by these IFRS.

The RBNZ's 2002-03 financial statements are used as a case study for various disclosures. However, it should be noted that:

- The RBNZ's financial statements are prepared in accordance with the requirements of New Zealand accounting standards. New Zealand accounting standards and disclosures reflect requirements considered appropriate to the New Zealand legal and economic situation and are not necessarily the same as the requirements of IAS.

- In addition, the RBNZ's financial statements contain disclosure requirements required under IFRS. However, the financial statements have not been prepared in accordance with the measurement and recognition requirements of IFRS. Therefore, the disclosures,

${ }^{20}$ Prepared by Richard Perry. 
which are specific to those measurement and recognition requirements, have not been made.

The disclosure examples are referenced as follows:
AP Accounting Policies
BS Balance Sheet or Statement of Financial Position
IS Income Statements or Statement of Financial Performance
CS Statement of Cost of Services
ME Statement of Movements in Equity
CFS Cash Flow Statement

\section{B. Contents of Financial Statements}

\begin{tabular}{|c|c|c|c|}
\hline$I A S$ & Para. & Requirements & RBNZ Example \\
\hline \multirow[t]{9}{*}{ IAS 1} & 8 & A complete set of financial statements comprises: & \\
\hline & $8(\mathrm{e})$ & Accounting Policies. & AP \\
\hline & $8(\mathrm{a})$ & Balance Sheet. & BS \\
\hline & $8(b)$ & Income Statement. & IS, CS \\
\hline & $8(\mathrm{c})$ & A statement of changes in equity showing either: & ME \\
\hline & & (i) All changes in equity; or & \\
\hline & & $\begin{array}{l}\text { (11) Changes in equity other than those arising from transactions } \\
\text { with equity holders acting in their capacity as equity holders. }\end{array}$ & \\
\hline & $8(\mathrm{~d})$ & Cash flow statement. & CFS \\
\hline & $8(\mathrm{e})$ & Explanatory Notes. & Notes to Accounts \\
\hline IAS 1 & 36 & $\begin{array}{l}\text { Except when a Standard or an Interpretation permits or requires } \\
\text { otherwise, comparative information shall be disclosed in respect of } \\
\text { the previous period for all amounts reported in the financial } \\
\text { statements. Comparative information shall be included for narrative } \\
\text { and descriptive information when it is relevant to an understanding } \\
\text { of the current period's financial statements. }\end{array}$ & $\begin{array}{l}\text { Comprehensive } \\
\text { comparatives are } \\
\text { provided. }\end{array}$ \\
\hline IAS 1 & 44 & $\begin{array}{l}\text { The financial statements shall be identified clearly and } \\
\text { distinguished from other information in the same published } \\
\text { document. }\end{array}$ & $\begin{array}{l}\text { See RBNZ table } \\
\text { of contents }\end{array}$ \\
\hline IAS 1 & 46 & $\begin{array}{l}\text { Each component of the financial statements shall be identified } \\
\text { clearly. In addition, the following information shall be displayed } \\
\text { prominently, and repeated when it is necessary for a proper } \\
\text { understanding of the information presented: } \\
\text { (a) the name of the reporting entity or other means of } \\
\text { identification, and any change in that information from the } \\
\text { proceeding balance sheet date; } \\
\text { (b) whether the financial statements cover the individual entity or } \\
\text { a group of entities; }\end{array}$ & In each statement \\
\hline
\end{tabular}




\begin{tabular}{|c|c|c|c|}
\hline$I A S$ & Para. & Requirements & RBNZ Example \\
\hline & & $\begin{array}{l}\text { (c) the balance sheet date or the period covered by the financial } \\
\text { statements, whichever is appropriate to that component of the } \\
\text { financial statements; } \\
\text { (d) presentation currency, as defined in IAS } 21 \text { The Effects of } \\
\text { Changes in Foreign Exchange Rates; and } \\
\text { (e) the level of rounding used in presenting amounts in the } \\
\text { financial statements. }\end{array}$ & \\
\hline IAS 1 & 49 & $\begin{array}{l}\text { Financial statements shall be presented at least annually. When an } \\
\text { entity's balance sheet date changes and the annual financial } \\
\text { statements are presented for a period longer or shorter than one } \\
\text { year, an entity shall disclose, in addition to the period covered by } \\
\text { the financial statements: } \\
\text { (a) The reason for using a longer or shorter period; and } \\
\text { (b) The fact that comparative amounts for the income statement, } \\
\text { statement of changes in equity, cash flow statement and } \\
\text { related notes are not entirely comparable. }\end{array}$ & $\begin{array}{l}\text { N/A } \\
\text { N/A } \\
\text { N/A }\end{array}$ \\
\hline
\end{tabular}

\section{Accounting Policies}

\begin{tabular}{|l|l|l|l|l|}
\hline IAS & Para. & Requirements & RBNZ Example & AP \\
\hline IAS 8 & 7 & $\begin{array}{l}\text { When a Standard or an interpretation specifically applies to a } \\
\text { transaction, other event or condition, the accounting policy or } \\
\text { policies applied to that item shall be determined by applying the } \\
\text { Standard or Interpretation and considering any relevant } \\
\text { Implementation Guidance issued by the IASB for the Standard or } \\
\text { Interpretation. }\end{array}$ & AP & In the absence of a Standard or an Interpretation that specifically \\
applies to a transaction, other event or condition, management shall \\
use its judgment in developing and applying an accounting policy \\
that results in information that is: \\
IAS 8 & 10 & $\begin{array}{l}\text { (a) } \begin{array}{l}\text { relevant to the economic decision-making needs of users; and } \\
\text { (b) } \text { reliable in that the financial statements: }\end{array} \\
\text { (i) represent faithfully the financial position, financial } \\
\text { performance and cash flows of the entity; } \\
\text { (ii) reflect the economic substance of transactions, other } \\
\text { events and conditions and not merely the legal form; } \\
\text { (iii) are neutral, i.e., free from bias; } \\
\text { (iv) are prudent; and } \\
\text { (v) are complete in all material respects. }\end{array}$ & \\
\hline
\end{tabular}




\begin{tabular}{|c|c|c|c|c|}
\hline$I A S$ & Para. & Requirements & RBNZ Example & $\Delta$ \\
\hline IAS 1 & 105 & $\begin{array}{l}\text { Notes are normally presented in the following order, which assists } \\
\text { users in understanding the financial statements and comparing them } \\
\text { with financial statements of other entities: } \\
\text { (a) a statement of compliance with IFRSs (see paragraph 14); } \\
\text { (b) a summary of significant accounting policies applied (see } \\
\text { paragraph 108); }\end{array}$ & $\begin{array}{l}\mathrm{AP}(\mathrm{a}) \\
\mathrm{AP}(\mathrm{b})-\mathrm{AP}(\mathrm{x})\end{array}$ & \\
\hline IAS 1 & 14 & $\begin{array}{l}\text { An entity whose financial statements comply with IFRSs shall } \\
\text { make an explicit and unreserved statement of such compliance in } \\
\text { the notes. Financial statements shall not be described as complying } \\
\text { with IFRSs unless they comply with all the requirements of IFRSs. }\end{array}$ & $\mathrm{N} / \mathrm{A}$ & \\
\hline IAS 1 & 17 & $\begin{array}{l}\text { In the extremely rare circumstances in which management } \\
\text { concludes that compliance with a requirement in a Standard or an } \\
\text { Interpretation would be so misleading that it would conflict with } \\
\text { the objective of financial statements set out in the Framework, the } \\
\text { entity shall depart from that requirement in the manner set out in } \\
\text { paragraph } 18 \text { if the relevant regulatory framework requires, or } \\
\text { otherwise does not prohibit, such a departure. }\end{array}$ & $\mathrm{N} / \mathrm{A}$ & \\
\hline IAS 1 & 18 & $\begin{array}{l}\text { When an entity departs from a requirement of a Standard or an } \\
\text { Interpretation in accordance with paragraph 17, it shall disclose: } \\
\text { (a) that management has concluded that the financial statements } \\
\text { present fairly the entity's financial position, financial } \\
\text { performance and cash flows; } \\
\text { that it has complied with applicable Standards and } \\
\text { Interpretations, except that it has departed from a particular } \\
\text { requirement to achieve a fair presentation; } \\
\text { the title of the Standard or Interpretation from which the } \\
\text { entity has departed, the nature of the departure, including the } \\
\text { treatment that the Standard or Interpretation would require, } \\
\text { the reason why that treatment would be so misleading in the } \\
\text { circumstances that it would conflict with the objective of } \\
\text { financial statements set out in the Framework, and the } \\
\text { treatment adopted; and } \\
\text { for each period presented, the financial impact of the } \\
\text { departure on each item in the financial statements that would } \\
\text { have been reported in complying with the requirement. }\end{array}$ & $\mathrm{N} / \mathrm{A}$ & \\
\hline IAS 1 & 103 & $\begin{array}{l}\text { The notes shall: } \\
\text { (a) Present information about the basis of preparation of the } \\
\text { financial statements and the specific accounting policies used } \\
\text { in accordance with paragraphs } 108-115 \text {. }\end{array}$ & AP & \\
\hline IAS 1 & 108 & $\begin{array}{l}\text { An entity shall disclose in the summary of significant accounting } \\
\text { policies: } \\
\text { (a) the measurement basis (or bases) used in preparing the } \\
\text { financial statements; and } \\
\text { (b) the other accounting policies used that are relevant to an } \\
\text { understanding of the financial statements. }\end{array}$ & $\begin{array}{l}\text { AP } \\
\text { AP }\end{array}$ & \\
\hline
\end{tabular}




\begin{tabular}{|c|c|c|c|c|}
\hline$I A S$ & Para. & Requirements & RBNZ Example & $\Delta$ \\
\hline IAS 1 & 110 & $\begin{array}{l}\text { In deciding whether a particular accounting policy should be } \\
\text { disclosed, management considers whether disclosure would assist } \\
\text { users in understanding how transactions, other events and } \\
\text { conditions are reflected in the reported financial performance and } \\
\text { financial position. Disclosure of particular accounting policies is } \\
\text { especially useful to users when those policies are selected from } \\
\text { alternatives allowed in Standards and Interpretations. }\end{array}$ & $\mathrm{AP}$ & \\
\hline IAS 1 & 113 & $\begin{array}{l}\text { An entity shall disclose, in the summary of significant accounting } \\
\text { policies or other notes, the judgments, apart from those involving } \\
\text { estimations (see paragraph } 116 \text { ), management has made in the } \\
\text { process of applying the entity's accounting policies that have the } \\
\text { most significant effect on the amounts recognized in the financial } \\
\text { statements. }\end{array}$ & AP & \\
\hline IAS 8 & 28 & $\begin{array}{l}\text { When initial application of a Standard or an Interpretation has an } \\
\text { effect on the current period or any prior period, would have such an } \\
\text { effect except that it is impracticable to determine the amount of the } \\
\text { adjustment, or might have an effect on future periods, an entity } \\
\text { shall disclose: } \\
\text { (a) the title of the Standard or Interpretation; } \\
\text { (b) when applicable, that the change in accounting policy is made } \\
\text { in accordance with its transitional provisions; } \\
\text { (c) the nature of the change in accounting policy; } \\
\text { (d) when applicable, a description of the transitional provisions; } \\
\text { (e) when applicable, the transitional provisions that might have } \\
\text { an effect on future periods; } \\
\text { for the current period and each prior period presented, to the } \\
\text { extent practicable, the amount of the adjustment: } \\
\text { (i) for each financial statement line item affected; and } \\
\text { (ii) if IAS } 33 \text { Earnings per Share applies to the entity, for } \\
\text { basic and diluted earnings per share; } \\
\text { (g) the amount of the adjustment relating to periods before those } \\
\text { presented, to the extent practicable; and } \\
\text { (h) if retrospective application required by paragraph 19(a) or (b) } \\
\text { is impracticable for a particular prior period, or for periods } \\
\text { before those presented, the circumstances that led to the } \\
\text { existence of that condition and a description of how and from } \\
\text { when the change in accounting policy has been applied. }\end{array}$ & $\mathrm{N} / \mathrm{A}$ & \\
\hline
\end{tabular}




\begin{tabular}{|c|c|c|c|c|}
\hline$I A S$ & Para. & Requirements & RBNZ Example & $>$ \\
\hline IAS 8 & 29 & $\begin{array}{l}\text { When a voluntary change in accounting policy has an effect on the } \\
\text { current period or any prior period, would have an effect on that } \\
\text { period except that it is impracticable to determine the amount of the } \\
\text { adjustment, or might have an effect on future periods, an entity } \\
\text { shall disclose: } \\
\text { (a) the nature of the change in accounting policy; } \\
\text { (b) the reasons why applying the new accounting policy provides } \\
\text { reliable and more relevant information; } \\
\text { for the current period and each prior period presented, to the } \\
\text { extent practicable, the amount of the adjustment: } \\
\text { (i) for each financial statement line item affected; and } \\
\text { (ii) if IAS } 33 \text { applies to the entity, for basic and diluted } \\
\text { earnings per share; } \\
\text { the amount of the adjustment relating to periods before those } \\
\text { presented, to the extent practicable; and } \\
\text { if retrospective application is impracticable for a particular } \\
\text { prior period, or for periods before those presented, the } \\
\text { circumstances that led to the existence of that condition and a } \\
\text { description of how and from when the change in accounting } \\
\text { policy has been applied. }\end{array}$ & $\mathrm{AP}(\mathrm{z})$ & \\
\hline IAS 8 & 30 & $\begin{array}{l}\text { When an entity has not applied a new Standard or Interpretation } \\
\text { that has been issued but is not yet effective, the entity shall } \\
\text { disclose: } \\
\text { (a) this fact; and } \\
\text { (b) known or reasonably estimable information relevant to } \\
\text { assessing the possible impact that application of the new } \\
\text { Standard or Interpretation will have on the entity's financial } \\
\text { statements in the period of initial application. }\end{array}$ & N/A & \\
\hline IAS 8 & 39 & $\begin{array}{l}\text { An entity shall disclose the nature and amount of a change in an } \\
\text { accounting estimate that has an effect in the current period or is } \\
\text { expected to have an effect in future periods, except for the } \\
\text { disclosure of the effect on future periods when it is impracticable to } \\
\text { estimate that effect. }\end{array}$ & N/A & \\
\hline IAS 8 & 40 & $\begin{array}{l}\text { If the amount of the effect in future periods is not disclosed because } \\
\text { estimating it is impracticable, an entity shall disclose that fact. }\end{array}$ & N/A & \\
\hline IAS 2 & 36 & $\begin{array}{l}\text { The financial statements shall disclose: } \\
\text { (a) the accounting policies adopted in measuring inventories, } \\
\text { including the cost formula used; }\end{array}$ & $\mathrm{AP}(\mathrm{m})$ & \\
\hline IAS 10 & 17 & $\begin{array}{l}\text { An entity shall disclose the date when the financial statements were } \\
\text { authorized for issue and who gave that authorization. If the entity's } \\
\text { owners or others have the power to amend the financial statements } \\
\text { after issue, the entity shall disclose that fact. }\end{array}$ & $\mathrm{AP}(\mathrm{a})$ & \\
\hline
\end{tabular}




\begin{tabular}{|c|c|c|c|c|}
\hline$I A S$ & Para. & Requirements & RBNZ Example & $\Delta$ \\
\hline IAS 18 & 35 & $\begin{array}{l}\text { An enterprise should disclose: } \\
\text { (a) the accounting policies adopted for the recognition of revenue } \\
\text { including the methods adopted to determine the stage of } \\
\text { completion of transactions involving the rendering of } \\
\text { services; }\end{array}$ & $\mathrm{AP}(\mathrm{f})$ & \\
\hline IAS 30 & 8 & $\begin{array}{l}\text { Banks use differing methods for the recognition and measurement } \\
\text { of items in their financial statements. In order to comply with IAS } \\
\text { 1, and thereby enable users to understand the basis on which the } \\
\text { financial statements of a bank are prepared, accounting policies } \\
\text { dealing with the following items may need to be disclosed: } \\
\text { (a) the recognition of the principal types of income (see } \\
\text { paragraphs } 10 \text { and 11); } \\
\text { (b) the valuation of investment and dealing securities (see } \\
\text { paragraphs } 24 \text { and 25); } \\
\text { (c) the distinction between those transactions and other events } \\
\text { that result in the recognition of assets and liabilities on the } \\
\text { balance sheet and those transactions and other events that only } \\
\text { give rise to contingencies and commitments (see paragraphs } \\
26 \text { to } 29 \text { ); } \\
\text { (d) basis for the determination of losses on loans and advances } \\
\text { and for writing off uncollectible loans and advances (see } \\
\text { paragraphs } 43 \text { to } 49 \text { ); and } \\
\text { (e) the basis for the determination of charges for general banking } \\
\text { risks and the accounting treatment of such charges (see } \\
\text { paragraphs } 50 \text { to } 52 \text { ). }\end{array}$ & $\begin{array}{l}\text { AP (f) } \\
\text { AP (f) } \\
\text { N/A }\end{array}$ & \\
\hline IAS 30 & 43 & $\begin{array}{l}\text { A bank shall disclose: } \\
\text { (a) The accounting policy that describes the basis on which } \\
\text { uncollectible loans and advances are recognized as an expense } \\
\text { and written off. }\end{array}$ & N/A & \\
\hline IAS 32 & $60(\mathrm{~b})$ & $\begin{array}{l}\text { For each class of financial asset, financial liability and equity } \\
\text { instrument, an entity shall disclose the accounting policies and } \\
\text { methods adopted, including the criteria for recognition and the } \\
\text { basis of measurement applied. }\end{array}$ & $\mathrm{AP}(\mathrm{f})$ & \\
\hline IAS 32 & 61 & $\begin{array}{l}\text { As part of the disclosure of an entity's accounting policies, an } \\
\text { entity shall disclose, for each category of financial assets, whether } \\
\text { regular way purchases and sales of financial assets are accounted } \\
\text { for at trade date or at settlement date (see IAS 39, paragraph 38). }\end{array}$ & $\mathrm{AP}(\mathrm{f})$ & \\
\hline
\end{tabular}




\begin{tabular}{|c|c|c|c|c|}
\hline$I A S$ & Para. & Requirements & RBNZ Example & $\Delta$ \\
\hline IAS 32 & 92 & $\begin{array}{l}\text { An entity shall disclose: } \\
\text { (a) me methods and significant assumptions applied in } \\
\text { determining fair values of financial assets and financial } \\
\text { liabilities separately for significant classes of financial assets } \\
\text { and financial liabilities. (Paragraph } 55 \text { provides guidance for } \\
\text { determining classes of financial assets.) } \\
\text { (b) whether fair values of financial assets and financial liabilities } \\
\text { are determined directly, in full or in part, by reference to } \\
\text { published price quotations in an active market or are } \\
\text { estimated using a valuation technique (see IAS 39, paragraphs } \\
\text { AG71-AG79). } \\
\text { whether its financial statements include financial instruments } \\
\text { measured at fair values that are determined in full or in part } \\
\text { using a valuation technique based on assumptions that are not } \\
\text { supported by observable market prices or rates. If changing } \\
\text { any such assumption to a reasonably possible alternative } \\
\text { would result in a significantly different fair value, the entity } \\
\text { shall state this fact and disclose the effect on the fair value of } \\
\text { a range of reasonably possible alternative assumptions. For } \\
\text { this purpose, significance shall be judged with respect to } \\
\text { profit or loss and total assets or total liabilities. }\end{array}$ & $\mathrm{AP}(\mathrm{f})$ & \\
\hline IAS 1 & 126 & $\begin{array}{l}\text { An entity shall disclose the following if not disclosed elsewhere in } \\
\text { information published with the financial statements: } \\
\text { (a) the domicile and legal form of the entity, its country of } \\
\text { incorporation and the address of its registered office (or } \\
\text { principal place of business, if different from the registered } \\
\text { office); } \\
\text { (b) a description of the nature of the entity's operations and its } \\
\text { principal activities; and } \\
\text { (c) the name of the parent and the ultimate parent of the group. }\end{array}$ & $\begin{array}{l}\text { Disclosed in body } \\
\text { of annual report } \\
\text { Note } 1 \\
\text { N/A }\end{array}$ & \\
\hline
\end{tabular}

\section{Balance Sheet}

\begin{tabular}{|c|c|c|c|c|}
\hline$I A S$ & Para. & Requirements & RBNZ Example & $\Delta$ \\
\hline IAS 1 & 51 & $\begin{array}{l}\text { An entity shall present current and non-current assets, and current } \\
\text { and non-current liabilities, as separate classifications on the face of } \\
\text { its balance sheet in accordance with paragraphs } 57-67 \text { except when } \\
\text { a presentation based on liquidity provides information that is } \\
\text { reliable and is more relevant. When that exception applies, all } \\
\text { assets and liabilities shall be presented broadly in order of liquidity. }\end{array}$ & $\begin{array}{l}\text { RBNZ uses broad } \\
\text { order of liquidity }\end{array}$ & \\
\hline IAS 1 & 52 & $\begin{array}{l}\text { Whichever method of presentation is adopted, for each asset and } \\
\text { liability line item that combines amounts expected to be recovered } \\
\text { or settled within (a) no more than twelve months after the balance } \\
\text { sheet date and (b) more than twelve months after the balance sheet } \\
\text { date, an entity shall disclose the amount expected to be recovered or } \\
\text { settled after more than twelve months. }\end{array}$ & Note 23 & \\
\hline
\end{tabular}




\begin{tabular}{|c|c|c|c|c|}
\hline$I A S$ & Para. & Requirements & RBNZ Example & $\Delta$ \\
\hline IAS 30 & 18 & $\begin{array}{l}\text { A bank should present a balance sheet that groups assets and } \\
\text { liabilities by nature and lists them in an order that reflects their } \\
\text { relative liquidity. }\end{array}$ & $\begin{array}{l}\text { RBNZ uses broad } \\
\text { order of liquidity }\end{array}$ & \\
\hline IAS 30 & 23 & $\begin{array}{l}\text { The amount at which any asset or liability is stated in the balance } \\
\text { sheet should not be offset by the deduction of another liability or } \\
\text { asset unless a legal right of set-off exists and the offsetting } \\
\text { represents the expectation as to the realization or settlement of the } \\
\text { asset or liability. }\end{array}$ & N/A & \\
\hline IAS 32 & 42 & $\begin{array}{l}\text { A financial asset and a financial liability shall be offset and the net } \\
\text { amount reported in the balance sheet when, and only when, an } \\
\text { entity: } \\
\text { (a) currently has a legally enforceable right to set off the } \\
\text { recognized amounts; and } \\
\text { (b) intends either to settle on a net basis, or to realize the asset and } \\
\text { settle the liability simultaneously. }\end{array}$ & N/A & \\
\hline IAS 1 & 68 & $\begin{array}{l}\text { As a minimum, the face of the balance sheet shall include line items } \\
\text { that present the following amounts: } \\
\text { (a) property, plant and equipment; } \\
\text { (b) investment property; } \\
\text { (c) intangible assets; } \\
\text { (d) financial assets (excluding amounts shown under (e), (h) and } \\
\text { (i)); } \\
\text { (e) investments accounted for using the equity method; } \\
\text { (f) biological assets; } \\
\text { (g) inventories; } \\
\text { (h) trade and other receivables; } \\
\text { (i) cash and cash equivalents; } \\
\text { (j) trade and other payables; } \\
\text { (k) provisions; } \\
\text { (l) financial liabilities (excluding amounts shown under (j) and } \\
\text { (k)); } \\
\text { (m) liabilities and assets for current tax, as defined in IAS } 12 \\
\text { (n) deferred tax liabilities and deferred tax assets, as defined in } \\
\text { IAS 12; } \\
\text { (o) minority interest, presented within equity; and } \\
\text { (p) issued capital and reserves attributable to equity holders of }\end{array}$ & $\begin{array}{l}\text { BS } \\
\text { N/A } \\
\text { N/A } \\
\text { BS } \\
\text { N/A } \\
\text { N/A } \\
\text { BS } \\
\text { BS } \\
\text { BS } \\
\text { BS \& Note } 10 \\
\text { Note } 11 \\
\text { BS } \\
\text { N/A } \\
\text { N/A } \\
\text { N/A } \\
\text { BS \& Note } 13\end{array}$ & \\
\hline IAS 30 & 19 & $\begin{array}{l}\text { In addition to the requirements of other IAS, the disclosures in the } \\
\text { balance sheet or the notes to the financial statements should } \\
\text { include, but are not limited to, the following assets and liabilities: }\end{array}$ & & \\
\hline
\end{tabular}




\begin{tabular}{|c|c|c|c|c|}
\hline$I A S$ & Para. & Requirements & RBNZ Example & $>$ \\
\hline & & $\begin{array}{l}\text { Assets } \\
\text { Cash and balances with the central bank; } \\
\text { Treasury bills and other bills eligible for rediscounting with the } \\
\text { central bank; } \\
\text { Government and other securities held for dealing purposes; } \\
\text { Placements with, and loans and advances to, other banks; } \\
\text { Other money market placements; } \\
\text { Loans and advances to customers; and } \\
\text { Investment securities. }\end{array}$ & $\begin{array}{l}\text { BS } \\
\text { N/A } \\
\text { BS } \\
\text { BS } \\
\text { BS } \\
\text { Note } 4 \\
\text { BS }\end{array}$ & \\
\hline IAS 30 & 19 & $\begin{array}{l}\text { Liabilities } \\
\text { Deposits from other banks; } \\
\text { Other money market deposits; } \\
\text { Amounts owed to other depositors; } \\
\text { Certificates of deposits; } \\
\text { Promissory notes and other liabilities, and } \\
\text { Other borrowed funds. }\end{array}$ & $\begin{array}{l}\text { BS } \\
\text { BS } \\
\text { BS } \\
\text { N/A } \\
\text { N/A } \\
\text { BS }\end{array}$ & \\
\hline IAS 1 & 69 & $\begin{array}{l}\text { Additional line items, headings and subtotals shall be presented on } \\
\text { the face of the balance sheet when such presentation is relevant to } \\
\text { an understanding of the entity's financial position. }\end{array}$ & $\begin{array}{l}\text { Foreign and Local } \\
\text { Currency split is } \\
\text { an example. }\end{array}$ & \\
\hline IAS 1 & 70 & $\begin{array}{l}\text { When an entity presents current and non-current assets, and current } \\
\text { and non-current liabilities, as separate classifications on the face of } \\
\text { its balance sheet, it shall not classify deferred tax assets (liabilities) } \\
\text { as current assets (liabilities). }\end{array}$ & $\mathrm{N} / \mathrm{A}$ & \\
\hline IAS 1 & 74 & $\begin{array}{l}\text { An entity shall disclose, either on the face of the balance sheet or in } \\
\text { the notes, further sub classifications of the line items presented, } \\
\text { classified in a manner appropriate to the entity's operations. }\end{array}$ & $\begin{array}{l}\text { Notes to accounts } \\
\text { present sub- } \\
\text { classifications. }\end{array}$ & \\
\hline
\end{tabular}




\begin{tabular}{|c|c|c|c|}
\hline$I A S$ & Para. & Requirements & RBNZ Example \\
\hline IAS 1 & 76 & $\begin{array}{l}\text { An entity shall disclose the following, either on the face of the } \\
\text { balance sheet or in the notes: } \\
\text { (a) for each class of share capital: } \\
\text { (i) the number of shares authorized; } \\
\text { (ii) the number of shares issued and fully paid, and issued but not } \\
\text { fully paid; } \\
\text { (iii) par value per share, or that the shares have no par value; } \\
\text { (iv) a reconciliation of the number of shares outstanding at the } \\
\text { beginning and at the end of the period; } \\
\text { (v) the rights, preferences and restrictions attaching to that class } \\
\text { including restrictions on the distribution of dividends and the } \\
\text { repayment of capital; } \\
\text { (vi) shares in the entity held by the entity or by its subsidiaries or } \\
\text { associates; and } \\
\text { (vii) shares reserved for issue under options and contracts for the } \\
\text { sale of shares, including the terms and amounts. }\end{array}$ & N/A \\
\hline & & $\begin{array}{l}\text { A description of the nature and purpose of each reserve } \\
\text { within equity. }\end{array}$ & Note 13 \\
\hline IAS 1 & 77 & $\begin{array}{l}\text { An entity without share capital, such as a partnership or trust, shall } \\
\text { disclose information equivalent to that required by paragraph } 76(\mathrm{a}) \text {, } \\
\text { showing changes during the period in each category of equity } \\
\text { interest, and the rights, preferences and restrictions attaching to } \\
\text { each category of equity interest. }\end{array}$ & Note 13 \\
\hline
\end{tabular}

\section{E. Income Statement}

\begin{tabular}{|c|c|c|c|c|}
\hline \multirow{2}{*}{\begin{tabular}{|l|}
$I A S$ \\
IAS 1
\end{tabular}} & \multirow{2}{*}{$\begin{array}{l}\text { Para. } \\
81\end{array}$} & \multirow{2}{*}{$\begin{array}{l}\text { Requirements } \\
\text { As a minimum, the face of the income statement shall include line } \\
\text { items that present the following amounts for the period: }\end{array}$} & \multirow[t]{2}{*}{ RBNZ Example } & \multirow[t]{2}{*}{$\Delta$} \\
\hline & & & & \\
\hline & & $\begin{array}{l}\text { (a) revenue; } \\
\text { (b) finance costs; } \\
\text { (c) share of the profit or loss of associates and joint ventures } \\
\text { accounted for using the equity method; } \\
\text { (d) pre-tax gain or loss recognized on the disposal of assets or } \\
\text { settlement of liabilities attributable to discontinuing } \\
\text { operations; } \\
\text { (e) tax expense; and } \\
\text { (f) profit or loss. }\end{array}$ & $\begin{array}{l}\text { IS } \\
\text { IS } \\
\text { N/A } \\
\text { N/A } \\
\text { N/A } \\
\text { IS }\end{array}$ & \\
\hline IAS 1 & 82 & $\begin{array}{l}\text { The following items shall be disclosed on the face of the income } \\
\text { statement as allocations of profit or loss for the period: } \\
\text { (a) profit or loss attributable to minority interest; and } \\
\text { (b) profit or loss attributable to equity holders of the parent. }\end{array}$ & $\begin{array}{l}\text { N/A } \\
\text { N/A }\end{array}$ & \\
\hline IAS 1 & 83 & $\begin{array}{l}\text { Additional line items, headings and subtotals shall be presented on } \\
\text { the face of the income statement when such presentation is relevant } \\
\text { to an understanding of the entity's financial performance. }\end{array}$ & $\begin{array}{l}\text { IS and } \\
\text { CS }\end{array}$ & \\
\hline
\end{tabular}




\begin{tabular}{|c|c|c|c|c|}
\hline$I A S$ & Para. & Requirements & RBNZ Example & $\Delta$ \\
\hline IAS 1 & 85 & $\begin{array}{l}\text { An entity shall not present any items of income and expense as } \\
\text { extraordinary items, either on the face of the income statement or in } \\
\text { the notes. }\end{array}$ & N/A & \\
\hline IAS 30 & 9 & $\begin{array}{l}\text { A bank should present an income statement which groups income } \\
\text { and expenses by nature and discloses the amounts of the principal } \\
\text { types of income and expenses. }\end{array}$ & IS & \\
\hline IAS 30 & 10 & $\begin{array}{l}\text { In addition to the requirements of other Standards, the disclosures } \\
\text { in the income statement or the notes to the financial statements } \\
\text { shall include, but are not limited to, the following items of income } \\
\text { and expenses: } \\
\text { Interest and similar income; } \\
\text { Interest expense and similar charges; } \\
\text { Dividend income; } \\
\text { Fee and commission income; } \\
\text { Fee and commission expense; } \\
\text { Gains less losses arising from dealing securities; } \\
\text { Gains less losses arising from investment securities; } \\
\text { Gains less losses arising from dealing in foreign currencies; } \\
\text { Other operating income; } \\
\text { Impairment losses on loans and advances; } \\
\text { General administrative expenses; and } \\
\text { Other operating expenses. }\end{array}$ & $\begin{array}{l}\text { Note } 28 \\
\text { Note } 29 \\
\text { N/A } \\
\text { Note } 32 \\
\text { Note } 34 \\
\text { Note } 25 \\
\text { Note } 24 \\
\text { Note } 25 \\
\text { Note } 32 \\
\text { N/A } \\
\text { IS } \\
\text { Note } 34\end{array}$ & \\
\hline IAS 1 & 88 & $\begin{array}{l}\text { An entity shall present an analysis of expenses using a classification } \\
\text { based on either the nature of expenses or their function within the } \\
\text { entity, whichever provides information that is reliable and more } \\
\text { relevant. } \\
\text { This requires expenses to be sub-classified in a manor appropriate } \\
\text { to the entity (see paragraph } 91 \text { and } 92 \text { for examples). }\end{array}$ & CS & \\
\hline IAS 1 & 89 & $\begin{array}{l}\text { Entities are encouraged to present the analysis in paragraph } 88 \text { on } \\
\text { the face of the income statement. }\end{array}$ & $\mathrm{CS}$ & \\
\hline IAS 1 & 93 & $\begin{array}{l}\text { Entities classifying expenses by function shall disclose additional } \\
\text { information on the nature of expenses, including depreciation and } \\
\text { amortization expense and employee benefits expense. }\end{array}$ & IS, CS \& Note 6 & \\
\hline IAS 1 & 95 & $\begin{array}{l}\text { An entity shall disclose, either on the face of the income statement, } \\
\text { or in the notes, the amount of dividends recognized as distributions } \\
\text { to equity holders during the period, and the related amount per } \\
\text { share. }\end{array}$ & $\begin{array}{l}\text { Note } 12 \text { presents } \\
\text { distribution of } \\
\text { profit }\end{array}$ & \\
\hline IAS 30 & 13 & $\begin{array}{l}\text { Income and expense items shall not be offset except for those } \\
\text { relating to hedges and to assets and liabilities that have been offset } \\
\text { in accordance with IAS } 32 \text {. } \\
\text { This requirement should be interpreted by reference to IAS } 39 \text { for } \\
\text { hedge accounting principles. }\end{array}$ & N/A & \\
\hline
\end{tabular}




\begin{tabular}{|c|c|c|c|c|}
\hline$I A S$ & Para. & Requirements & RBNZ Example & $\Delta$ \\
\hline IAS 32 & 94(h) & $\begin{array}{l}\text { An entity shall disclose material items of income, expense and } \\
\text { gains and losses resulting from financial assets and financial } \\
\text { liabilities, whether included in profit or loss or as a separate } \\
\text { component of equity. For this purpose, the disclosure shall include } \\
\text { at least the following items: } \\
\text { (i) total interest income and total interest expense (calculated } \\
\text { using the effective interest method) for financial assets and } \\
\text { financial liabilities that are not at fair value through profit or } \\
\text { loss; } \\
\text { (ii) for available-for-sale financial assets, the amount of any gain } \\
\text { or loss recognized directly in equity during the period and the } \\
\text { amount that was removed from equity and recognized in } \\
\text { profit or loss for the period; and } \\
\text { the amount of interest income accrued on impaired financial } \\
\text { assets, in accordance with IAS 39, paragraph AG93. }\end{array}$ & $\begin{array}{l}\text { IS } \\
\text { Notes } 28-31 \\
\text { Notes } 28 \& 29 \\
\text { N/A } \\
\text { N/A }\end{array}$ & \\
\hline IAS 32 & 94(i) & $\begin{array}{l}\text { An entity shall disclose the nature and amount of any impairment } \\
\text { loss recognized in profit or loss for a financial asset, separately for } \\
\text { each significant class of financial asset (IAS } 32 \text { paragraph } 55 \\
\text { provides guidance for determining classes of financial assets). }\end{array}$ & $\mathrm{N} / \mathrm{A}$ & \\
\hline IAS 21 & 52 & $\begin{array}{l}\text { An entity shall disclose: } \\
\text { (a) the amount of exchange differences recognized in profit or } \\
\text { loss except for those arising on financial instruments } \\
\text { measured at fair value through profit or loss in accordance } \\
\text { with IAS 39; }\end{array}$ & IS, Note 31 & \\
\hline
\end{tabular}

\section{F. Statement of Changes in Equity}

\begin{tabular}{|c|c|c|c|c|}
\hline$I A S$ & Para. & Requirements & RBNZ Example & $\Delta$ \\
\hline IAS 1 & 96 & $\begin{array}{l}\text { An entity shall present a statement of changes in equity showing on } \\
\text { the face of the statement: }\end{array}$ & $\mathrm{ME}$ & \\
\hline & & $\begin{array}{l}\text { (a) profit or loss for the period; } \\
\text { (b) each item of income and expense for the period that, as } \\
\text { required by other Standards or by Interpretations, is } \\
\text { recognized directly in equity, and the total of these items; } \\
\text { total income and expense for the period (calculated as the } \\
\text { sum of (a) and (b)), showing separately the total amounts } \\
\text { attributable to equity holders of the parent and to minority } \\
\text { interest; and } \\
\text { for each component of equity, the effects of changes in } \\
\text { accounting policies and corrections of errors recognized in } \\
\text { accordance with IAS 8. }\end{array}$ & N/A & \\
\hline
\end{tabular}




\begin{tabular}{|c|c|c|c|c|}
\hline$I A S$ & Para. & Requirements & RBNZ Example & $\Delta$ \\
\hline IAS 1 & 97 & $\begin{array}{l}\text { An entity shall also present, either on the face of the statement of } \\
\text { changes in equity or in the notes: } \\
\text { (a) the amounts of transactions with equity holders acting in their } \\
\text { capacity as equity holders, showing separately distributions to } \\
\text { equity holders; } \\
\text { (b) the balance of retained earnings (i.e., accumulated profit or } \\
\text { loss) at the beginning of the period and at the balance sheet } \\
\text { date, and the changes during the period; and } \\
\text { (c) a reconciliation between the carrying amount of each class of } \\
\text { contributed equity and each reserve at the beginning and the } \\
\text { end of the period, separately disclosing each change. }\end{array}$ & $\begin{array}{l}\text { N/A } \\
\text { Note } 12 \\
\text { Note } 13\end{array}$ & \\
\hline IAS 32 & 94(h) & $\begin{array}{l}\text { An entity shall disclose material items of income, expense and } \\
\text { gains and losses resulting from financial assets and financial } \\
\text { liabilities, whether included in profit or loss or as a separate } \\
\text { component of equity. For this purpose, the disclosure shall include } \\
\text { at least the following items: } \\
\text { (ii) for available-for-sale financial assets, the amount of any gain } \\
\text { or loss recognized directly in equity during the period and the } \\
\text { amount that was removed from equity and recognized in } \\
\text { profit or loss for the period; }\end{array}$ & $\mathrm{N} / \mathrm{A}$ & \\
\hline IAS 21 & 52 & $\begin{array}{l}\text { An entity shall disclose: } \\
\text { (b) net exchange differences classified in a separate component of } \\
\text { equity, and a reconciliation of the amount of such exchange } \\
\text { differences at the beginning and end of the period; }\end{array}$ & N/A & \\
\hline
\end{tabular}

\section{G. Cash Flow Statement}

\begin{tabular}{|c|c|c|c|c|}
\hline$I A S$ & Para. & Requirements & RBNZ Example & $\Delta$ \\
\hline IAS 7 & 1 & $\begin{array}{l}\text { An enterprise should prepare a cash flow statement in accordance } \\
\text { with the requirements of this Standard and should present it as an } \\
\text { integral part of its financial statements for each period for which } \\
\text { financial statements are presented. }\end{array}$ & CFS & \\
\hline IAS 7 & 10 & $\begin{array}{l}\text { The cash flow statement should report cash flows, during the period } \\
\text { classified by operating, investing and financing activities. }\end{array}$ & CFS & \\
\hline IAS 7 & 18 & $\begin{array}{l}\text { An enterprise should report cash flows from operating activities } \\
\text { using either: } \\
\text { (a) The direct method, whereby major classes of gross cash } \\
\text { receipts and gross cash payments are disclosed; or } \\
\text { (b) The indirect method, whereby net profit or loss is adjusted for } \\
\text { the effects of transactions of a non-cash nature, any deferrals } \\
\text { or accruals of past or future operating cash receipts or } \\
\text { payments, and items of income or expense associated with } \\
\text { investing or financing cash flows. }\end{array}$ & $\begin{array}{l}\text { CFS } \\
\text { CFS } \\
\text { Note } 36\end{array}$ & \\
\hline
\end{tabular}




\begin{tabular}{|c|c|c|c|c|}
\hline$I A S$ & Para. & Requirements & RBNZ Example & $\Delta$ \\
\hline IAS 7 & 21 & $\begin{array}{l}\text { An enterprise should report separately major classes of gross cash } \\
\text { receipts and gross cash payments arising from investing and } \\
\text { financing activities, except to the extent that cash flows described } \\
\text { in paragraph } 22 \text { and } 24 \text { are reported on a net basis. }\end{array}$ & CFS & \\
\hline IAS 7 & 22 & $\begin{array}{l}\text { Cash flows arising from the following operating, investing or } \\
\text { financing activities may be reported on a net basis: } \\
\text { (a) Cash receipts and payments on behalf of customers when the } \\
\text { cash flows reflect the activities of the customer rather than } \\
\text { those of the enterprise; and } \\
\text { (b) Cash receipts and payments for items in which the turnover is } \\
\text { quick, the amounts are large, and the maturities are short. }\end{array}$ & CFS & \\
\hline IAS 7 & 24 & $\begin{array}{l}\text { Cash flows arising from each of the following activities of a } \\
\text { financial institution may be reported on a net basis: } \\
\text { (a) Cash receipts and payments for the acceptance and repayment } \\
\text { of deposits with a fixed maturity date; } \\
\text { (b) The placement of deposits with and withdrawal of deposits } \\
\text { from other financial institutions; and } \\
\text { (c) Cash advances and loans made to customers and the } \\
\text { repayment of those advances and loans. }\end{array}$ & CFS & \\
\hline IAS 7 & 29 & $\begin{array}{l}\text { The cash flows associated with extraordinary items should be } \\
\text { classified as arising from operating, investing or financing activities } \\
\text { as appropriate and separately disclosed. }\end{array}$ & $\mathrm{N} / \mathrm{A}$ & \\
\hline IAS 7 & 31 & $\begin{array}{l}\text { Cash flows from interest and dividends received and paid should } \\
\text { each be disclosed separately. Each should be classified in a } \\
\text { consistent manner from period to period as either operating, } \\
\text { investing or financing activities. }\end{array}$ & CFS & \\
\hline IAS 7 & 35 & $\begin{array}{l}\text { Cash flows arising from taxes on income should be separately } \\
\text { disclosed and should be classified as cash flows from operating } \\
\text { activities unless they can be specifically identified with financing } \\
\text { and investing activities. }\end{array}$ & CFS & \\
\hline IAS 7 & 39 & $\begin{array}{l}\text { The aggregate cash flows arising from acquisitions and from } \\
\text { disposals of subsidiaries or other business units should be presented } \\
\text { separately and classified as investing activities. }\end{array}$ & $\mathrm{N} / \mathrm{A}$ & \\
\hline IAS 7 & 43 & $\begin{array}{l}\text { Investing and financing activities that do not require the use of cash } \\
\text { or cash equivalents should be excluded from a cash flow statement. } \\
\text { Such transactions should be disclosed elsewhere in the financial } \\
\text { statements in a way that provides all the relevant information about } \\
\text { these investing and financing activities. }\end{array}$ & N/A & \\
\hline
\end{tabular}




\begin{tabular}{|l|l|l|l|l|}
\hline IAS & Para. & Requirements & RBNZ Example & Note 37 \\
\hline IAS 7 & 45 & $\begin{array}{l}\text { An enterprise should disclose the components of cash and cash } \\
\text { equivalents and should present a reconciliation of the amounts in its } \\
\text { cash flow statement with the equivalent items reported in the } \\
\text { balance sheet. }\end{array}$ & $\begin{array}{l}\text { An enterprise should disclose, together with a commentary by } \\
\text { management, the amount of significant cash and cash equivalent } \\
\text { balances held by the enterprise that are not available for use by the } \\
\text { group. }\end{array}$ & N/A \\
\hline IAS 7 & 48 & & \\
\hline
\end{tabular}

\section{H. Notes to the Accounts (Excluding Accounting Policies)}

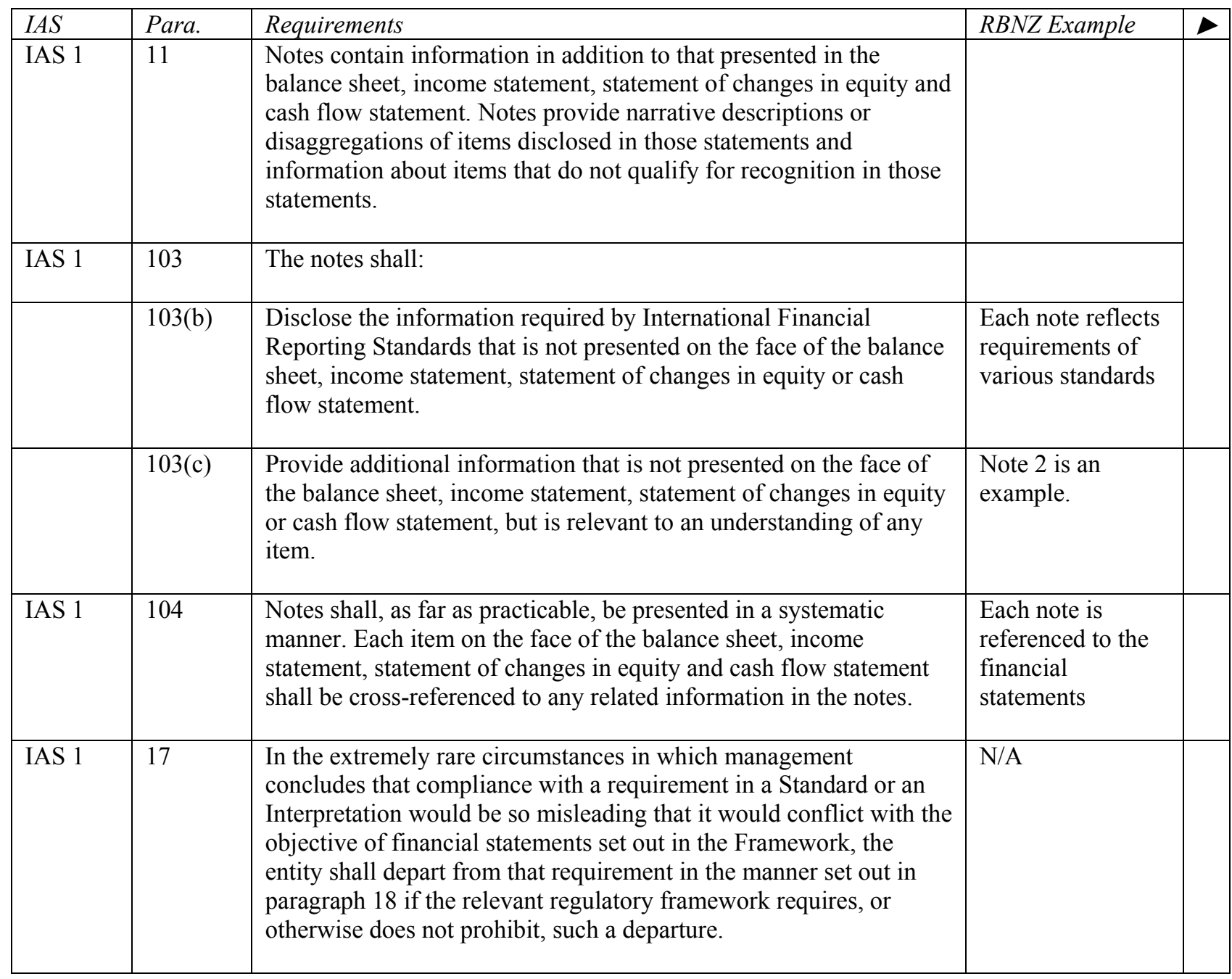




\begin{tabular}{|c|c|c|c|c|}
\hline$I A S$ & Para. & Requirements & RBNZ Example & $\Delta$ \\
\hline IAS 1 & 116 & $\begin{array}{l}\text { An entity shall disclose in the notes information about the key } \\
\text { assumptions concerning the future, and other key sources of } \\
\text { estimation uncertainty at the balance sheet date, that have a } \\
\text { significant risk of causing a material adjustment to the carrying } \\
\text { amounts of assets and liabilities within the next financial year. } \\
\text { In respect of those assets and liabilities, the notes shall include } \\
\text { details of: } \\
\text { (a) their nature; and } \\
\text { (b) their carrying amount as at the balance sheet date. }\end{array}$ & N/A & \\
\hline IAS 1 & 125 & $\begin{array}{l}\text { An entity shall disclose in the notes: } \\
\text { (a) the amount of dividends proposed or declared before the } \\
\text { financial statements were authorized for issue but not } \\
\text { recognized as a distribution to equity holders during the period, } \\
\text { and the related amount per share; and } \\
\text { (b) the amount of any cumulative preference dividends not } \\
\text { recognized. }\end{array}$ & $\begin{array}{l}\text { Dividends are } \\
\text { disclosed in note } \\
12 .\end{array}$ & \\
\hline IAS 2 & 36 & $\begin{array}{l}\text { The financial statements shall disclose: } \\
\text { (b) the total carrying amount of inventories and the carrying } \\
\text { amount in classifications appropriate to the entity; } \\
\text { (c) the carrying amount of inventories carried at fair value less } \\
\text { costs to sell; } \\
\text { (d) the amount of inventories recognized as an expense during the } \\
\text { period; } \\
\text { (e) the amount of any write-down of inventories recognized as an } \\
\text { expense in the period in accordance with paragraph 34; } \\
\text { (f) the amount of any reversal of any write-down that is } \\
\text { recognized as a reduction in the amount of inventories } \\
\text { recognized as expense in the period in accordance with } \\
\text { paragraph } 34 \text {; } \\
\text { (g) the circumstances or events that led to the reversal of a write- } \\
\text { down of inventories in accordance with paragraph } 34 \text {; and } \\
\text { (h) the carrying amount of inventories pledged as security for } \\
\text { liabilities. }\end{array}$ & $\begin{array}{l}\text { Note } 5 \\
\text { N/A } \\
\text { Note } 24 \\
\text { N/A } \\
\text { N/A } \\
\text { N/A }\end{array}$ & \\
\hline IAS 10 & 19 & $\begin{array}{l}\text { If an entity receives information after the balance sheet date about } \\
\text { conditions that existed at the balance sheet date, it shall update } \\
\text { disclosures that relate to those conditions, in the light of the new } \\
\text { information. }\end{array}$ & N/A & \\
\hline IAS 10 & 21 & $\begin{array}{l}\text { If non-adjusting events after the balance sheet date are material, } \\
\text { non-disclosure could influence the economic decisions of users } \\
\text { taken on the basis of the financial statements. Accordingly, an } \\
\text { entity shall disclose the following for each material category of } \\
\text { non-adjusting event after the balance sheet date: } \\
\text { (a) the nature of the event; and } \\
\text { (b) an estimate of its financial effect or a statement that such an } \\
\text { estimate cannot be made. }\end{array}$ & $\mathrm{N} / \mathrm{A}$ & \\
\hline
\end{tabular}




\begin{tabular}{|c|c|c|c|}
\hline$I A S$ & Para. & Requirements & RBNZ Example \\
\hline IAS 16 & 73 & $\begin{array}{l}\text { The financial statements shall disclose, for each class of property, } \\
\text { plant and equipment: } \\
\text { (a) the measurement bases used for determining the gross } \\
\text { carrying amount; } \\
\text { (b) the depreciation methods used; } \\
\text { (c) the useful lives or the depreciation rates used; } \\
\text { (d) the gross carrying amount and the accumulated depreciation } \\
\text { (aggregated with accumulated impairment losses) at the } \\
\text { beginning and end of the period; and } \\
\text { (e) a reconciliation of the carrying amount at the beginning and } \\
\text { end of the period showing: } \\
\text { (i) additions; } \\
\text { (ii) disposals; } \\
\text { (iii) acquisitions through business combinations; } \\
\text { (iv) increases or decreases resulting from revaluations under } \\
\text { paragraphs } 31,39 \text { and } 40 \text { and from impairment losses } \\
\text { recognized or reversed directly in equity in accordance with } \\
\text { IAS } 36 \text {; } \\
\text { (v) impairment losses recognized in profit or loss in accordance } \\
\text { with IAS } 36 \text {; } \\
\text { (vi) impairment losses reversed in profit or loss in accordance } \\
\text { with IAS } 36 \text {; } \\
\text { (vii) depreciation; } \\
\text { (viii) the net exchange differences arising on the translation of the } \\
\text { financial statements from the functional currency into a } \\
\text { different presentation currency, including the translation of a } \\
\text { foreign operation into the presentation currency of the } \\
\text { other changes. }\end{array}$ & $\begin{array}{l}A P(i) \text { and } A P(j) \\
A P(i) \text { and } A P(j) \\
A P(i) \text { and } A P(j) \\
\text { Note } 6\end{array}$ \\
\hline IAS 16 & 74 & $\begin{array}{l}\text { The financial statements shall also disclose: } \\
\text { (a) the existence and amounts of restrictions on title, and property, } \\
\text { plant and equipment pledged as security for liabilities; } \\
\text { (b) the amount of expenditures recognized in the carrying amount } \\
\text { of an item of property, plant and equipment in the course of its } \\
\text { construction; } \\
\text { (c) the amount of contractual commitments for the acquisition of } \\
\text { property, plant and equipment; and } \\
\text { (d) if it is not disclosed separately on the face of the income } \\
\text { statement, the amount of compensation from third parties for } \\
\text { items of property, plant and equipment that were impaired, lost } \\
\text { or given up that is included in profit or loss. }\end{array}$ & $\begin{array}{l}\text { N/A } \\
\text { N/A } \\
\text { Note } 38 \\
\text { N/A }\end{array}$ \\
\hline
\end{tabular}




\begin{tabular}{|c|c|c|c|c|}
\hline$I A S$ & Para. & Requirements & RBNZ Example & $\Delta$ \\
\hline IAS 16 & 77 & $\begin{array}{l}\text { If items of property, plant and equipment are stated at revalued } \\
\text { amounts, the following shall be disclosed: } \\
\text { (a) the effective date of the revaluation; } \\
\text { (b) whether an independent valuer was involved; } \\
\text { (c) the methods and significant assumptions applied in } \\
\text { estimating the items' fair values; } \\
\text { (d) the extent to which the items' fair values were determined } \\
\text { directly by reference to observable prices in an active market } \\
\text { or recent market transactions on arm's length terms or were } \\
\text { estimated using other valuation techniques; } \\
\text { for each revalued class of property, plant and equipment, the } \\
\text { carrying amount that would have been recognized had the } \\
\text { assets been carried under the cost model; and } \\
\text { the revaluation surplus, indicating the change for the period } \\
\text { and any restrictions on the distribution of the balance to } \\
\text { shareholders. }\end{array}$ & $\begin{array}{l}\text { Note } 6 \\
\text { Note } 6 \\
\text { Not included } \\
\text { Not included } \\
\text { Note } 6 \\
\text { Note } 13\end{array}$ & \\
\hline IAS 17 & 31 & $\begin{array}{l}\text { Lessees shall, in addition to meeting the requirements of IAS } 32 \\
\text { Financial Instruments: Disclosure and Presentation, make the } \\
\text { following disclosures for finance leases: } \\
\text { (a) for each class of asset, the net carrying amount at the balance } \\
\text { sheet date. } \\
\text { (b) a reconciliation between the total of future minimum lease } \\
\text { payments at the balance sheet date, and their present value. In } \\
\text { addition, an entity shall disclose the total of future minimum } \\
\text { lease payments at the balance sheet date, and their present } \\
\text { value, for each of the following periods: } \\
\text { (i) not later than one year; } \\
\text { (ii) later than one year and not later than five years; } \\
\text { (iii) later than five years. } \\
\text { (c) contingent rents recognized as an expense in the period. } \\
\text { (d) the total of future minimum sublease payments expected to be } \\
\text { received under noncancelable subleases at the balance sheet } \\
\text { date. } \\
\text { (e) a general description of the lessee's material leasing } \\
\text { arrangements including, but not limited to, the following: } \\
\text { (i) the basis on which contingent rent payable is determined; } \\
\text { (ii) the existence and terms of renewal or purchase options and } \\
\text { escalation clauses; and } \\
\text { (iii) restrictions imposed by lease arrangements, such as those } \\
\text { concerning dividends, additional debt, and further leasing. }\end{array}$ & $\begin{array}{l}\text { Note } 6 \\
\text { Note } 38 \\
\text { N/A } \\
\text { N/A } \\
\text { Note } 38\end{array}$ & \\
\hline
\end{tabular}




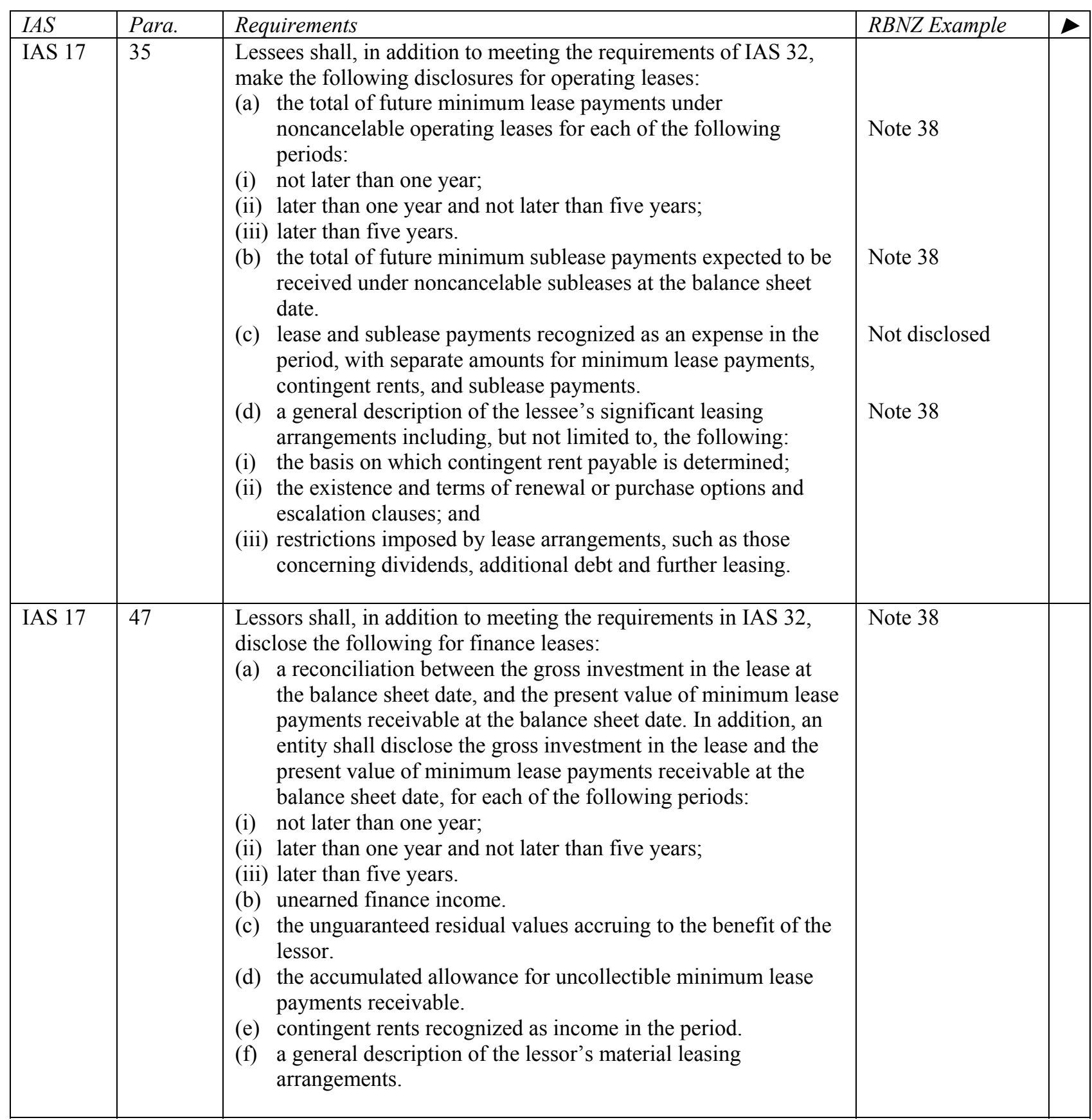




\begin{tabular}{|c|c|c|c|c|}
\hline$I A S$ & Para. & Requirements & RBNZ Example & $>$ \\
\hline IAS 17 & 56 & $\begin{array}{l}\text { Lessors shall, in addition to meeting the requirements of IAS } 32 \text {, } \\
\text { disclose the following for operating leases: } \\
\text { (a) the future minimum lease payments under noncancelable } \\
\text { operating leases in the aggregate and for each of the following } \\
\text { periods: } \\
\text { (i) not later than one year; } \\
\text { (ii) later than one year and not later than five years; } \\
\text { (iii) later than five years. } \\
\text { (b) total contingent rents recognized as income in the period. } \\
\text { (c) a general description of the lessor's leasing arrangements. }\end{array}$ & $\begin{array}{l}\text { Note } 38 \\
\text { N/A } \\
\text { Note } 38\end{array}$ & \\
\hline IAS 18 & 35 & $\begin{array}{l}\text { An enterprise should disclose: } \\
\text { (b) the amount of each significant category of revenue recognized } \\
\text { during the period including revenue arising from: } \\
\text { (i) the sale of goods; } \\
\text { (ii) the rendering of services; } \\
\text { (iii) interest; } \\
\text { (iv) royalties; } \\
\text { (v) dividends; and } \\
\text { (c) the amount of revenue arising from exchanges of goods or } \\
\text { services included in each significant category of revenue. }\end{array}$ & $\begin{array}{l}\text { IS } \\
\text { CS } \\
\text { Notes } 28-32\end{array}$ & \\
\hline IAS 24 & 12 & $\begin{array}{l}\text { Relationships between parents and subsidiaries shall be disclosed } \\
\text { irrespective of whether there have been transactions between those } \\
\text { related parties. An entity shall disclose the name of the entity's } \\
\text { parent and, if different, the ultimate controlling party. If neither the } \\
\text { entity's parent nor the ultimate controlling party produces financial } \\
\text { statements available for public use, the name of the next most } \\
\text { senior parent that does so shall also be disclosed. }\end{array}$ & Note 41 & \\
\hline IAS 24 & 16 & $\begin{array}{l}\text { An entity shall disclose key management personnel compensation } \\
\text { in total and for each of the following categories: } \\
\text { (a) short-term employee benefits; } \\
\text { (b) post-employment benefits; } \\
\text { (c) other long-term benefits; } \\
\text { (d) termination benefits; and } \\
\text { (e) equity compensation benefits. }\end{array}$ & $\begin{array}{l}\text { Note } 35 \text { and in } \\
\text { other parts on } \\
\text { annual report } \\
\text { (remuneration } \\
\text { table) }\end{array}$ & \\
\hline
\end{tabular}




\begin{tabular}{|c|c|c|c|c|}
\hline$I A S$ & Para. & Requirements & RBNZ Example & $>$ \\
\hline IAS 24 & 17 & $\begin{array}{l}\text { If there have been transactions between related parties, an entity } \\
\text { shall disclose the nature of the related party relationship as well as } \\
\text { information about the transactions and outstanding balances } \\
\text { necessary for an understanding of the potential effect of the } \\
\text { relationship on the financial statements. These disclosure } \\
\text { requirements are in addition to the requirements in paragraph } 16 \text { to } \\
\text { disclose key management personnel compensation. At a minimum, } \\
\text { disclosures shall include: } \\
\text { (a) the amount of the transactions; } \\
\text { (b) the amount of outstanding balances and: } \\
\text { (i) their terms and conditions, including whether they are } \\
\text { secured, and the nature of the consideration to be provided } \\
\text { in settlement; and } \\
\text { (ii) details of any guarantees given or received; } \\
\text { (c) provisions for doubtful debts related to the amount of } \\
\text { outstanding balances; and } \\
\text { (d) the expense recognized during the period in respect of bad or } \\
\text { doubtful debts due from related parties. }\end{array}$ & Note 41 & \\
\hline IAS 24 & 18 & $\begin{array}{l}\text { The disclosures required by paragraph } 17 \text { shall be made separately } \\
\text { for each of the following categories: } \\
\text { (a) the parent; } \\
\text { (b) entities with joint control or significant influence over the } \\
\text { entity; } \\
\text { (c) subsidiaries; } \\
\text { (d) associates; } \\
\text { (e) joint ventures in which the entity is a venturer; } \\
\text { (f) key management personnel of the entity or its parent; and } \\
\text { (g) other related parties. }\end{array}$ & Note 41 & \\
\hline IAS 30 & 26 & $\begin{array}{l}\text { A bank should disclose the following contingencies and } \\
\text { commitments: } \\
\text { (a) The nature and amount of commitments to extend credit that } \\
\text { are irrevocable because they cannot be withdrawn at the } \\
\text { discretion of the bank without the risk of incurring significant } \\
\text { penalty or expense; and } \\
\text { (b) The nature and amount of contingencies and commitments } \\
\text { arising from off balance sheet items including those relating } \\
\text { to: }\end{array}$ & N/A & \\
\hline
\end{tabular}




\begin{tabular}{|c|c|c|c|c|}
\hline$I A S$ & Para. & Requirements & RBNZ Example & $\Delta$ \\
\hline & & $\begin{array}{l}\text { (i) direct credit substitutes including general guarantees of } \\
\text { indebtedness, bank acceptance guarantees and standby letters } \\
\text { of credit serving as financial guarantees for loans and } \\
\text { securities. } \\
\text { (ii) certain transaction-related contingencies including } \\
\text { performance bonds, bid bonds, warranties and standby letters } \\
\text { of credit related to particular transactions; } \\
\text { (iii) short-term self-liquidating trade-related contingencies arising } \\
\text { from the movement of goods, such as documentary credits } \\
\text { where the underlying shipment is used as security; and } \\
\text { (iv) other commitments, note issuance facilities and revolving } \\
\text { underwriting facilities. }\end{array}$ & N/A & \\
\hline IAS 30 & 30 & $\begin{array}{l}\text { A bank should disclose an analysis of assets and liabilities into } \\
\text { relevant maturity groupings based on the remaining period at the } \\
\text { balance sheet date to the contractual maturity date. }\end{array}$ & Note 23 & \\
\hline IAS 32 & 56 & $\begin{array}{l}\text { An entity shall describe its financial risk management objectives } \\
\text { and policies, including its policy for hedging each main type of } \\
\text { forecast transaction for which hedge accounting is used. }\end{array}$ & $\begin{array}{l}\text { Notes } 16,17,18 \\
19,20,21,22\end{array}$ & \\
\hline IAS 32 & 60 & $\begin{array}{l}\text { For each class of financial asset, financial liability and equity } \\
\text { instrument, an entity shall disclose } \\
\text { (a) information about the extent and nature of the financial } \\
\text { instruments, including significant terms and conditions that } \\
\text { may affect the amount, timing and certainty of future cash } \\
\text { flows. }\end{array}$ & Note 1 & \\
\hline IAS 32 & 67 & $\begin{array}{l}\text { For each class of financial assets and financial liabilities an entity } \\
\text { shall disclose information about its exposure to interest rate risk, } \\
\text { including: } \\
\text { (a) contractual repricing or maturity dates, whichever dates are } \\
\text { earlier; and } \\
\text { (b) effective interest rates, when applicable. }\end{array}$ & Note 19 and 21 & \\
\hline IAS 32 & 76 & $\begin{array}{l}\text { For each class of financial asset and other credit exposures, an } \\
\text { entity shall disclose information about its exposure to credit risk, } \\
\text { including: } \\
\text { (a) the amount that best represents its maximum credit risk } \\
\text { exposure at the balance sheet date, without taking account of } \\
\text { the fair value of any collateral, in the event other parties fail } \\
\text { to perform their obligations under financial instruments; and } \\
\text { (b) significant concentrations of credit risk. }\end{array}$ & $\begin{array}{l}\text { Note } 18 \text { (c) } \\
\text { Note } 18(\mathrm{~b})\end{array}$ & \\
\hline IAS 30 & 40 & $\begin{array}{l}\text { A bank should disclose any significant concentrations of its assets, } \\
\text { liabilities and off balance sheet items. Such disclosures should be } \\
\text { made in terms of geographical areas, customer or industry groups } \\
\text { or other concentrations of risk. }\end{array}$ & Note 18 (b) & \\
\hline
\end{tabular}




\begin{tabular}{|c|c|c|c|c|}
\hline$I A S$ & Para. & Requirements & RBNZ Example & $\Delta$ \\
\hline IAS 30 & 43(b) & $\begin{array}{l}\text { A bank shall disclose: } \\
\text { Details of the movements in any allowance for impairment losses } \\
\text { on loans and advances during the period. It shall disclose } \\
\text { separately the amount recognized as an expense in the period for } \\
\text { impairment losses on uncollectible loans and advances, the amount } \\
\text { charged in the period for loans and advances written off and the } \\
\text { amount credited in the period for loans and advances previously } \\
\text { written off that have been recovered. }\end{array}$ & N/A & \\
\hline & $43(\mathrm{c})$ & $\begin{array}{l}\text { The aggregate amount of an allowance account for impairment } \\
\text { losses on loans and advances at the balance sheet date. }\end{array}$ & N/A & \\
\hline IAS 30 & 44 & $\begin{array}{l}\text { Any amounts set aside in respect of losses on loans and advances in } \\
\text { addition to impairment losses recognized under IAS } 39 \text { on loans } \\
\text { and advances shall be accounted for as appropriations of retained } \\
\text { earnings. Any credits resulting from the reduction of such amounts } \\
\text { result in an increase in retained earnings and are not included in the } \\
\text { determination of net profit or loss for the period. }\end{array}$ & $\mathrm{N} / \mathrm{A}$ & \\
\hline IAS 30 & 50 & $\begin{array}{l}\text { Any amounts set aside in respect of general banking risks, } \\
\text { including future losses and other unforeseeable risks or } \\
\text { contingencies should be separately disclosed as appropriations of } \\
\text { retained earnings. Any credits resulting from the reduction of such } \\
\text { amounts result in an increase in retained earnings and are not } \\
\text { included in the determination of net profit or loss for the period. }\end{array}$ & $\mathrm{N} / \mathrm{A}$ & \\
\hline IAS 30 & 53 & $\begin{array}{l}\text { A bank should disclose the aggregate amount of secured liabilities } \\
\text { and the nature and carrying amount of the assets pledged as } \\
\text { security. }\end{array}$ & Note 1 (f) & \\
\hline IAS 30 & 24 & $\begin{array}{l}\text { A Bank shall disclose the fair values of each class of its financial } \\
\text { assets and liabilities as required by IAS } 32 \text {. }\end{array}$ & Note 14 & \\
\hline IAS 32 & 86 & $\begin{array}{l}\text { Except as set out in paragraph 90, for each class of financial assets } \\
\text { and financial liabilities, an entity shall disclose the fair value of that } \\
\text { class of assets and liabilities in a way that permits it to be } \\
\text { compared with the corresponding carrying amount in the balance } \\
\text { sheet. (IAS } 39 \text { provides guidance for determining fair value). }\end{array}$ & Note 14 & \\
\hline IAS 32 & 90 & $\begin{array}{l}\text { If investments in unquoted equity instruments or derivatives linked } \\
\text { to such equity instruments are measured at cost under IAS } 39 \\
\text { because their fair value cannot be measured reliably, that fact shall } \\
\text { be disclosed together with a description of the financial } \\
\text { instruments, their carrying amount, an explanation of why fair } \\
\text { value cannot be measured reliably and, if possible, the range of } \\
\text { estimates within which fair value is highly likely to lie. } \\
\text { Furthermore, if financial assets whose fair value previously could } \\
\text { not be reliably measured are sold, that fact, the carrying amount of } \\
\text { such financial assets at the time of sale and the amount of gain or } \\
\text { loss recognized shall be disclosed. }\end{array}$ & N/A & \\
\hline
\end{tabular}




\begin{tabular}{|c|c|c|c|c|}
\hline$I A S$ & Para. & Requirements & RBNZ Example & $>$ \\
\hline IAS 32 & 92 & $\begin{array}{l}\text { An entity shall disclose: } \\
\text { (d) the total amount of the change in fair value estimated using a } \\
\text { valuation technique that was recognized in profit or loss } \\
\text { during the period. }\end{array}$ & N/A & \\
\hline IAS 32 & 58 & $\begin{array}{l}\text { An entity shall disclose the following separately for designated fair } \\
\text { value hedges, cash flow hedges and hedges of a net investment in a } \\
\text { foreign operation (as defined in IAS 39): } \\
\text { (a) a description of the hedge; } \\
\text { (b) a description of the financial instruments designated as } \\
\text { hedging instruments and their fair values at the balance sheet } \\
\text { date; } \\
\text { (c) the nature of the risks being hedged; and } \\
\text { (d) for cash flow hedges, the periods in which the cash flows are } \\
\text { expected to occur, when they are expected to enter into the } \\
\text { determination of profit or loss, and a description of any } \\
\text { forecast transaction for which hedge accounting had } \\
\text { previously been used, but which is no longer expected to } \\
\text { occur. }\end{array}$ & N/A & \\
\hline IAS 32 & 59 & $\begin{array}{l}\text { When a gain or loss on a hedging instrument in a cash flow hedge } \\
\text { has been recognized directly in equity, through the statement of } \\
\text { changes in equity, an entity shall disclose: } \\
\text { (a) the amount that was so recognized in equity during the period; } \\
\text { (b) the amount that was removed from equity and included in } \\
\text { profit or loss for the period; and } \\
\text { (c) the amount that was removed from equity during the period } \\
\text { and included in the initial measurement of the acquisition cost } \\
\text { or other carrying amount of a non-financial asset or non- } \\
\text { financial liability in a hedged highly probable forecast } \\
\text { transaction. }\end{array}$ & N/A & \\
\hline IAS 32 & 94 (a) & $\begin{array}{l}\text { An entity may have either transferred a financial asset } \\
\text { (see paragraph } 18 \text { of IAS 39) or entered into the type of } \\
\text { arrangement described in paragraph } 19 \text { of IAS } 39 \text { in such a way } \\
\text { that the arrangement does not qualify as a transfer of a financial } \\
\text { asset. If the entity either continues to recognize all of the asset or } \\
\text { continues to recognize the asset to the extent of the entity's } \\
\text { continuing involvement (see IAS } 39 \text {, paragraphs } 29 \text { and 30) it shall } \\
\text { disclose for each class of financial asset: } \\
\text { (i) the nature of the assets; } \\
\text { (ii) the nature of the risks and rewards of ownership to which the } \\
\text { entity remains exposed; } \\
\text { (iii) when the entity continues to recognize all of the asset, the } \\
\text { carrying amounts of the asset and of the associated liability; } \\
\text { and } \\
\text { (iv) when the entity continues to recognize the asset to the extent } \\
\text { of its continuing involvement, the total amount of the asset, } \\
\text { the amount of the asset that the entity continues to recognize } \\
\text { and the carrying amount of the associated liability. }\end{array}$ & N/A & \\
\hline
\end{tabular}




\begin{tabular}{|c|c|c|c|c|}
\hline$I A S$ & Para. & Requirements & RBNZ Example & $\Delta$ \\
\hline IAS 32 & 94 (b) & $\begin{array}{l}\text { An entity shall disclose the carrying amount of financial assets } \\
\text { pledged as collateral for liabilities, the carrying amount of financial } \\
\text { assets pledged as collateral for contingent liabilities, and } \\
\text { (consistently with paragraphs } 60 \text { (a) and } 63(\mathrm{~g}) \text { ) any material terms } \\
\text { and conditions relating to assets pledged as collateral. }\end{array}$ & Note 1(f) & \\
\hline IAS 32 & $94(\mathrm{c})$ & $\begin{array}{l}\text { When an entity has accepted collateral that it is permitted to sell or } \\
\text { repledge in the absence of default by the owner of the collateral, it } \\
\text { shall disclose: } \\
\text { (i) the fair value of the collateral accepted (financial and non- } \\
\text { financial assets); } \\
\text { (ii) the fair value of any such collateral sold or repledged and } \\
\text { whether the entity has an obligation to return it; and } \\
\text { (iii) any material terms and conditions associated with its use of } \\
\text { this collateral (consistently with paragraphs } 60(\mathrm{a}) \text { and } 63(\mathrm{~g}) \text { ). }\end{array}$ & $\begin{array}{l}\text { Note } 1(\mathrm{f}) \\
\text { Note } 18(\mathrm{a})\end{array}$ & \\
\hline IAS 32 & $94(d)$ & $\begin{array}{l}\text { If an entity has issued an instrument that contains both a liability } \\
\text { and an equity component (see paragraph } 28 \text { ) and the instrument has } \\
\text { multiple embedded derivative features whose values are } \\
\text { interdependent (such as a callable convertible debt instrument), it } \\
\text { shall disclose the existence of those features and the effective } \\
\text { interest rate on the liability component (excluding any embedded } \\
\text { derivatives that are accounted for separately). }\end{array}$ & N/A & \\
\hline IAS 32 & $94(\mathrm{e})$ & $\begin{array}{l}\text { An entity shall disclose the carrying amounts of financial assets } \\
\text { and financial liabilities that: } \\
\text { (i) are classified as held for trading; and } \\
\text { (ii) were, upon initial recognition, designated by the entity as } \\
\text { financial assets and financial liabilities at fair value through } \\
\text { profit or loss (i.e., those that are not financial instruments } \\
\text { classified as held for trading). }\end{array}$ & N/A & \\
\hline IAS 32 & 94 (f) & $\begin{array}{l}\text { If the entity has designated a financial liability as at fair value } \\
\text { through profit or loss, it shall disclose: } \\
\text { (i) the amount of change in its fair value that is not attributable to } \\
\text { changes in a benchmark interest rate (e.g., LIBOR); and } \\
\text { (ii) the difference between its carrying amount and the amount the } \\
\text { entity would be contractually required to pay at maturity to the } \\
\text { holder of the obligation. }\end{array}$ & Not done & \\
\hline IAS 32 & $94(\mathrm{~g})$ & $\begin{array}{l}\text { If the entity has reclassified a financial asset as one measured at } \\
\text { cost or amortized cost rather than at fair value (see IAS } 39 \text {, } \\
\text { paragraph 54), it shall disclose the reason for that reclassification. }\end{array}$ & AP & \\
\hline IAS 32 & $94(j)$ & $\begin{array}{l}\text { With respect to any defaults of principal, interest, sinking fund or } \\
\text { redemption provisions during the period on loans payable } \\
\text { recognized as at the balance sheet date, and any other breaches } \\
\text { during the period of loan agreements when those breaches can } \\
\text { permit the lender to demand repayment (except for breaches that } \\
\text { are remedied, or in response to which the terms of the loan are } \\
\text { renegotiated, on or before the balance sheet date), an entity shall } \\
\text { disclose: }\end{array}$ & N/A & \\
\hline
\end{tabular}




\begin{tabular}{|c|c|c|c|c|}
\hline$I A S$ & Para. & Requirements & RBNZ Example & $\Delta$ \\
\hline & & $\begin{array}{l}\text { (i) details of those breaches; } \\
\text { (ii) the amount recognized as at the balance sheet date in respect } \\
\text { of the loans payable on which the breaches occurred; and } \\
\text { (iii) with respect to amounts disclosed under (ii), whether the } \\
\text { default has been remedied or the terms of the loans payable } \\
\text { renegotiated before the date the financial statements were } \\
\text { authorized for issue. }\end{array}$ & & \\
\hline IAS 37 & 84 & $\begin{array}{l}\text { For each class of provision, an enterprise should disclose: } \\
\text { (a) the carrying amount at the beginning and end of the period; } \\
\text { (b) additional provisions made in the period, including increases } \\
\text { to existing provisions; } \\
\text { (c) amounts used (i.e., incurred and charged against the provision) } \\
\text { during the period; } \\
\text { (d) unused amounts reversed during the period; and } \\
\text { (e) the increase during the period in the discounted amount arising } \\
\text { from the passage of time and the effect of any change in the } \\
\text { discount rate. }\end{array}$ & Note 11 & \\
\hline IAS 37 & 85 & $\begin{array}{l}\text { An enterprise should disclose the following for each class of } \\
\text { provision: } \\
\text { (a) a brief description of the nature of the obligation and the } \\
\text { expected timing of any resulting outflows of economic } \\
\text { benefits; } \\
\text { (b) an indication of the uncertainties about the amount or timing } \\
\text { of those outflows. Where necessary to provide adequate } \\
\text { information, an enterprise should disclose the major } \\
\text { assumptions made concerning future events, as addressed in } \\
\text { paragraph 48; and } \\
\text { (c) the amount of any expected reimbursement, stating the amount } \\
\text { of any asset that has been recognized for that expected } \\
\text { reimbursement. }\end{array}$ & Note 11 & \\
\hline IAS 37 & 86 & $\begin{array}{l}\text { Unless the possibility of any outflow in settlement is remote, an } \\
\text { enterprise should disclose for each class of contingent liability at } \\
\text { the balance sheet date a brief description of the nature of the } \\
\text { contingent liability and, where practicable: } \\
\text { (a) an estimate of its financial effect, measured under paragraphs } \\
36-52 \text {; } \\
\text { (b) an indication of the uncertainties relating to the amount or } \\
\text { timing of any outflow; and } \\
\text { (c) the possibility of any reimbursement. }\end{array}$ & Note 42 & \\
\hline IAS 37 & 89 & $\begin{array}{l}\text { Where an inflow of economic benefits is probable, an enterprise } \\
\text { should disclose a brief description of the nature of the contingent } \\
\text { assets at the balance sheet date, and, where practicable, an estimate } \\
\text { of their financial effect, measured using the principles set out for } \\
\text { provisions in paragraphs } 36-52 \text {. }\end{array}$ & $\mathrm{N} / \mathrm{A}$ & \\
\hline
\end{tabular}


RESERVE BANK OF NEW ZEALAND-FinANCIAL StATEMENTS 2002-2003

This appendix contains pages 49-100 of the Reserve Bank of New Zealand 2003 Annual Report.

http://www.rbnz.govt.nz/about/Whatwedo/0094054.html 


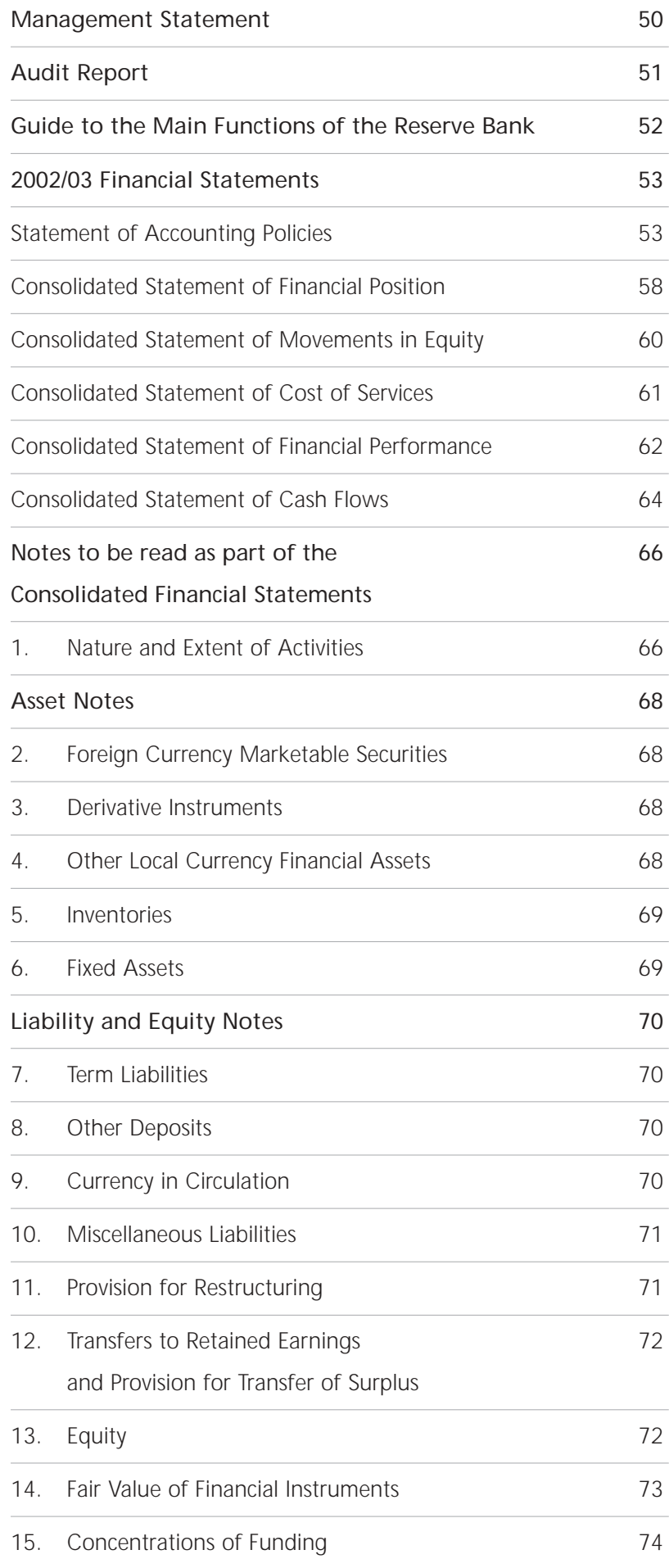

$\begin{array}{ll}\text { Risk Management Notes } & 76\end{array}$

16. Risk Management 76

17. Operational Risk 77

18. Credit Risk 77

19. Interest Rate Risk 81

20. Foreign Currency Risk 84

21. Market Risk 85

22. Liquidity Risk 87

23. Maturity Analysis 88

Consolidated Statement of Cost of Services Notes $\quad 90$

24. Currency Operations 90

25. Foreign Reserves Management 90

26. Overseas Investment Commission Secretariat 91

27. Registry and Depository Services 92

Consolidated Statement of Financial Performance Notes 93

28. Interest Income from Financial Assets 93

29. Interest Expense on Financial Liabilities 93

30. Gain/Loss from Market Value Changes 94

31. Net Foreign Exchange Revaluation Gain (Loss) 94

32. Other Income 94

33. Asset M anagement Expenses 95

34. Other Operating Expenses 95

35. Non-Executive Directors' Remuneration 96

Other Notes $\quad 96$

36. Reconciliation of Operating Cash Flows 96 with Reported Operating Surplus

37. Consolidated Cash Balances 97

38. Statement of Commitments 97

39. Subsidiary Companies 98

40. Free Services 98

41. Related Parties 99

42. Contingent Liabilities 99

43. Income Tax 100

44. Custodial Activities 100 
RESERVE

BANK

O F N E W Z E A L A N D

15 August 2003

\section{MANAGEMENT STATEMENT}

Pursuant to section 165 of the Reserve Bank of New Zealand Act 1989, we hereby certify that:

1. We have been responsible for the preparation of the annual financial statements and for the judgements used in them.

2. We have been responsible for establishing and maintaining a system of intemal controls designed to provide reasonable assurance as to the integrity and reliability of the Bank's financial reporting.

3. In our opinion, the annual financial statements for the year ended 30 June 2003 fairly reflect the financial position and operations of the Bank.
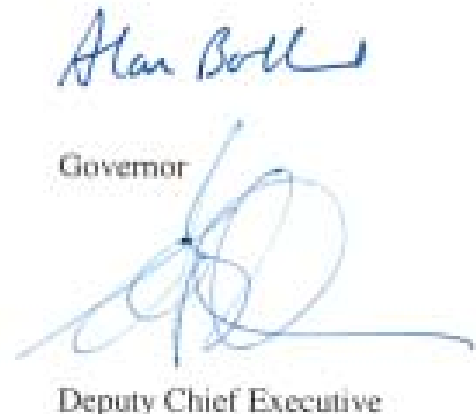

Deputy Chicf Executive 


\section{PRICEWATERHOUSECOOPERS 圈}

\section{REPORT OF THE AUDTTOH-GENFBAL \\ TO THE RE.ADFRS OF THE FINANCIAL STATEMFNTS OF THE RESERVE BANK OE NEW ZEALAND AND GROUP FOR THE YEAR ENDFI 30 JUNE 2003}

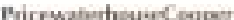
11)-110 The Serait ivo lins 241

We aave udised the fauncial stalements on pages 5.3 is 600 . The financial suemems provide iafismation atout the past

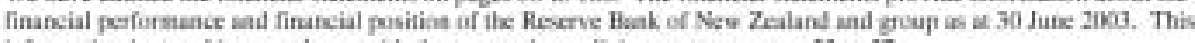
isformatise is starod in accundanct with the aporuming policios set obl on pags 53 is 57 .

\section{Respesdigities of the Cererane}

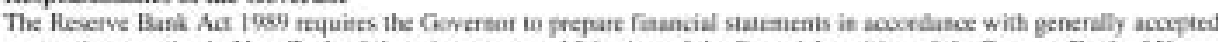
occonating practice in New Zealand that five a tree aad fait view of the financial position of the Reserye Bank of New Zealatd and grimp as at 30 Juse 2003 and the stsults of operations and cast nows for tec year efded en that date

\section{Auditar's Respoasihilities}

Section Is of the Public Adit Act 2001 requines the Aadion-Geferal is andit the financial staiemens presenied by the

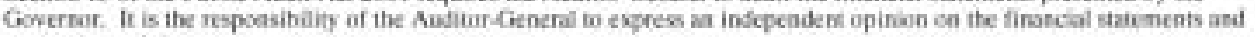
nepcet that opinion to yre.

The Audion-General tas appoinied Jin Chin of PricewaierhouseCocpen to enderate the audn.

\section{Rasis ef Opinian}

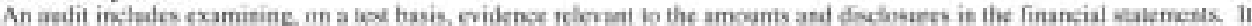
also indudes nossine:

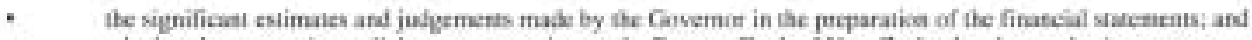
- Whether the accoustine policies are appropeiate to the Reserve Baik of New Zealand and group's circuanstances. crassistently applied and adeqaately dicebsed.

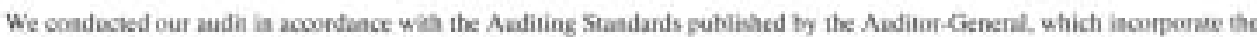

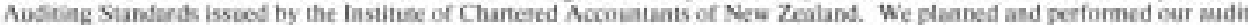

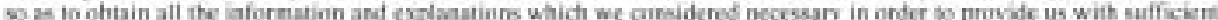

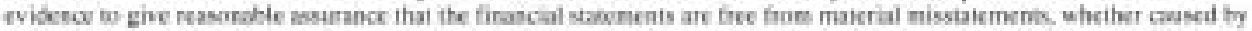

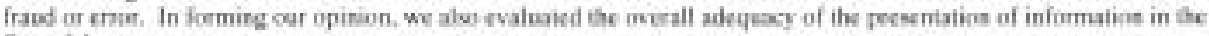
financial staiemenis.

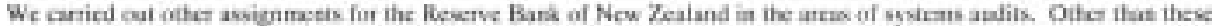

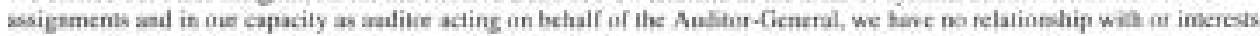
in the Reserve Batk of Neo Zealand ie any of its sulniliaries.

\section{Dequalified Opinise}

We have chained all ae infumation and explanations os have sequetd.

Is me opinise:

* prrper accouncing reconds tave heen kepi tor the Hexerye Bark of New Zealand and snoup as far as aprears from our evareinstion of three necards and

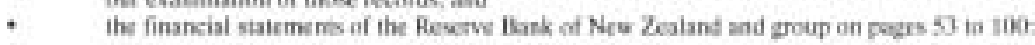

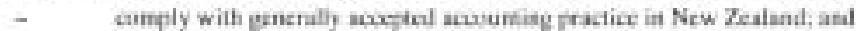

- gine a irae and fair view of

the Reverve Band of New Zealand and poup's finatsial position as at 30 Juse 2009; and the foults of operaines uad cash Rous for ihe yeaf ested en then date.

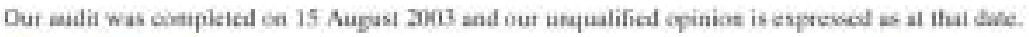

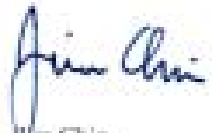

Win Chin

Oa tekalf of the Aadilot-Ceneral

Wellingsa, Neu Zealun.

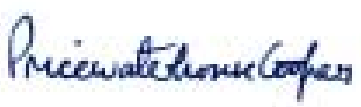

Prictuatethasecloopers 
For the purpose of this Annual Report and for the Reserve Bank's planning and budgeting processes the Bank classifies its outputs according to the main functions in the ways described below. Definitions of each output are described below.

\section{Monetary Policy Formulation:}

Formulating and publicly presenting monetary policy to enable the Bank to maintain price stability, in the most efficient manner possible.

\section{Market Operations:}

Trading, liaising with and monitoring financial markets, to effectively implement monetary policy and maintain the Bank's capacity to intervene in financial markets in support of the orderly and competitive functioning of those markets.

\section{Financial System Oversight:}

Registering and supervising banks, promoting the efficiency and soundness of the New Zealand financial system and limiting the significant damage to the financial system that could arise from a bank failure or other financial system distress.

\section{Currency Operations:}

Maintaining the supply and integrity of legal tender currency to facilitate cash transactions in the community.

\section{Foreign Reserves Management:}

Maintaining the capability to counter circumstances of severe illiquidity in our foreign exchange market and maintaining the Bank's foreign reserves at a level and in a form suitable for foreign exchange market intervention.

\section{Settlement Services:}

Providing settlement services to the government, financial institutions and appropriate overseas institutions to meet their banking needs and to facilitate effective implementation of monetary policy.

\section{Overseas Investment Commission Secretariat:}

Providing the secretariat of the Overseas Investment Commission. The Commission administers New Zealand's legislative controls on major inward foreign direct investment.

\section{Registry and Depository Services:}

Providing high quality depository, registry and settlement services to the securities market.

\section{Other Outputs:}

Producing other outputs which cannot be classified under the Bank's main functions. These include sundry economic policy advice and overseas representation and liaison. 


\section{STATEMENT OF ACCOUNTING POLICIES}

\section{(a) Reporting Entity and Statutory Base}

These are the consolidated financial statements of the Reserve Bank of New Zealand, a body corporate under the Reserve Bank of New Zealand Act 1989 (the "Act"). These statements apply to the financial year ended 30 June 2003. They are prepared in accordance with part VI of the Act and comply with generally accepted accounting practice in New Zealand. In addition, the Reserve Bank's financial statements contain disclosure requirements required under International Financial Reporting Standards. How ever, the financial statements have not been prepared in accordance with the measurement and recognition requirements of International Financial Reporting Standards. Therefore, the disclosures which are specific to those measurement and recognition requirements have not been made.

In these financial statements, the Reserve Bank of New Zealand is also referred to as the "Reserve Bank" or the "Bank".

The Governor of the Reserve Bank authorised these financial statements for issue on 15 August 2003.

\section{(b) Measurement Base}

The financial statements are prepared on the historical cost basis, modified by the revaluation of certain assets and liabilities as identified in specific accounting polices below.

\section{(c) Currency of Presentation}

All amounts are expressed in New Zealand dollars unless otherwise stated.

\section{(d) Basis of Consolidation}

The consolidated financial statements are prepared using the purchase method. All material inter-company balances and transactions are eliminated. Parent financial statements are not produced because the difference between the parent and group accounts is not material.

\section{(e) Foreign Currency Conversions}

Transactions in foreign currencies are translated to New Zealand dollars using exchange rates applying on the trade date of transactions. Foreign currency financial assets and financial liabilities are translated to New Zealand dollars using mid-market exchange rates applying at balance date. The following New Zealand dollar exchange rates for major currencies are used to convert foreign currency assets and liabilities to New Zealand dollars for reporting purposes:

$2003 \quad 2002$

Euro

$0.5104 \quad 0.4923$

Japanese yen

78.38

58.44

United States dollars

0.5877

0.4880

\section{(f) Financial Assets and Liabilities}

The Bank presents financial assets and liabilities, and the associated income and expense streams, by distinguishing between foreign currency and local currency activities. Foreign currency activities mainly arise from the Bank's Foreign Reserves M anagement function. Local currency activities mainly reflect the assets and liabilities associated with the Market Operations function and investment of the proceeds of issuing circulating currency.

The separate reporting of these activities is considered to provide a better presentation of the Bank's financial position, financial performance and risk profile. The Bank considers that the combined reporting of foreign and local currency activities would weaken the information value of the financial statements.

All financial assets and liabilities are recognised in the Statement of Financial Position on a trade date basis. This means that purchases and sales of financial instruments are recognised from the date at which the purchase or sale is agreed.

Foreign Currency Marketable Securities

Foreign currency marketable securities are valued at quoted mid-market prices. Any premium or discount on purchase is capitalised and amortised over the term of the security on a constant yield to maturity basis. Changes in market value are recognised as an increase or decrease in the value of Marketable Securities in the Statement of Financial Position.

Gains and losses arising from changes in the market value of foreign currency marketable securities are recognised in the Statement of Financial Performance as Gain (Loss) from Market Value Changes. 
Foreign Currency Term Liabilities

Foreign Currency Term Liabilities are reported at market or fair value. The funds from these liabilities are invested in foreign currency marketable securities. This valuation policy ensures consistency with the policy adopted for the corresponding assets. Market or fair value is imputed by deriving the fair value rate from the relevant market yield curve of similar liabilities and discounting the future cash flows of the liabilities at this rate. Changes in the value of these liabilities are recognised as an increase or decrease in the value of the Term Liabilities in the Statement of Financial Position.

Gains and losses arising from changes in market value of foreign currency term liabilities are recognised in the Statement of Financial Performance as Loss (Gain) from Market Value Changes.

Repurchase and Reverse-Repurchase Transactions

Securities sold under agreements to repurchase continue to be recorded as Marketable Securities in the Statement of Financial Position. The obligation to repurchase is disclosed within liabilities as Securities Sold Under Agreements to Repurchase. The difference between the sale and repurchase price represents an expense and is amortised over the term of the contract and reported in the Statement of Financial Performance.

Securities held under reverse-repurchase agreements are recorded within assets as Securities Purchased Under Agreements to Re-sell. The difference between the purchase price and sale price represents income and is amortised over the term of the contract and reported in the Statement of Financial Performance.

Both repurchase and reverse-repurchase transactions are reported at the transaction value inclusive of any accrued income or expense.

Securities Lending Programme

Securities lent out under the securities lending programme are accounted for on the same basis as repurchase and reverse-repurchase transactions.

Derivative Instruments

The Bank's involvement in derivative instruments comprises forward foreign exchange swap contracts, interest rate futures and interest rate swaps. Forward foreign exchange swap contracts are revalued for changes in exchange rates and are reported at fair value. This revaluation is imputed by deriving the fair value rate from the relevant market yield curve of similar contracts and discounting the future cash flows of the contracts at this rate. Interest receivable or payable and changes in fair value are recognised in the Statement of Financial Performance as Liquidity Management Swap Income.

Interest rate futures are reported in the Statement of Financial Position at quoted mid-market prices. Changes in market value are recognised in the Statement of Financial Performance as Other Foreign Currency Income (Loss). M argin and cash accounts arising from interest rate futures are recognised in the Statement of Financial Position as Other Cash Balances.

Interest rate swaps are reported at fair value in the Statement of Financial Position. The fair value is derived by discounting the future cash flows based on the relevant market yield curves. Interest receivable or payable and changes in fair value are recognised in the Statement of Financial Performance as Other Foreign Currency Income (Loss). Collateral taken under an interest rate swap arrangement is not recognised by the Bank in the Statement of Financial Position. Collateral delivered under an interest rate swap arrangement remains in the Statement of Financial Position.

All derivative instruments in a gain position are reported within the balance of foreign currency Marketable Securities in the Statement of Financial Position. Derivative instruments in a loss position are reported in the Statement of Financial Position as Derivative Instruments in a Loss Position. Derivative instruments in a loss position are offset against derivative instruments in a gain position where a legal right of set-off exists.

\section{Short Sales of Marketable Securities}

A "short sale" is a sale of a security that the Bank does not own. Short sales arise as part of the foreign reserves management function (see note 1) and the net returns on short sales are reported as income generated through active management trading (see note 25). Securities that are sold short are recorded at quoted market prices and reported as Short Sales of M arketable Securities in the Statement of Financial Position. Any gains or losses are recognised in the Statement of Financial Performance on the same basis as foreign currency Marketable Securities. 


\section{Unsettled Transactions}

Unsettled transactions are security purchases or sales that have been agreed but are yet to be settled. Amounts payable for unsettled purchases of securities are reported as liabilities under the title Payable for Unsettled Purchases of Securities. Amounts due from unsettled sales of securities are reported as assets under the title Receivable from Unsettled Sales of Securities.

Unsettled transactions are reported at the contract value.

Investment Portfolio - NZ Government Securities

The Bank's investment portfolio is accounted for on a constant yield to maturity basis. This reflects the intention to hold the portfolio until maturity as these assets represent the investment of the proceeds from issuing currency and the Bank's equity. Any premium or discount on purchase is capitalised and amortised over the term of the security on a constant yield to maturity basis. The portfolio is recorded in the Statement of Financial Position at historic cost adjusted for amortisation of any premium or discount on purchase. Interest is accrued in the Statement of Financial Performance as Local Currency Interest Income.

Market Test Activities

From time to time, the Bank may hold small trading positions in local currency securities as part of market test activities. These are valued at quoted market prices. Changes in market value are recognised as an increase or decrease in the value of Other Local Currency Financial Assets. Gains or losses are recognised in the Statement of Financial Performance as Gain (Loss) from Market Test Activities.

Other Financial Assets and Liabilities

Local and foreign currency cash, deposits and short-term advances are valued at transaction date value.

\section{(g) Currency in Circulation}

Currency issued by the Reserve Bank represents a claim on the Bank in favour of the holder. The liability for currency in circulation is recorded at face value in the Statement of Financial Position.

\section{(h) Collectors' and Demonetised Currency}

The Reserve Bank has a liability for the face value of collectors' currency. However, it is most unlikely that significant amounts of collectors' currency will be returned for redemption. Therefore, the face value of collectors' currency is recognised as a contingent liability.

The Bank has a liability for the face value of demonetised currency still in circulation. This is recognised as a contingent liability except for a portion retained in the Statement of Financial Position to cover expected future redemptions.

\section{(i) Land and Buildings}

Land is carried at market value. Buildings are carried at depreciated market value. In respect of the specialised basement and ground floor occupied by the Reserve Bank, market value is determined based on depreciated replacement cost. Surpluses of book value over historic cost for this class of asset are recorded in the Properties Revaluation Reserve. Where the book value of this class of asset falls below historic cost, previous revaluations are reversed and any remaining balance is charged as an expense in the financial year it occurs. Independent valuations of this class of asset are obtained every five years. Future valuations will be performed at highest and best use rather than existing use, and disposal costs will not be deducted. Buildings are depreciated on a straight line basis over 40 years.

\section{(j) Other Fixed Assets}

Other Fixed Assets are carried at cost less depreciation. The following assets held by the Reserve Bank are depreciated on a straight line basis over the following terms:

Computer Hardware and Software

3-5 years

Plant and Equipment

5 years

Building Improvements

8 years

M iscellaneous

expected useful life 


\section{(k) Leases}

\section{Operating Leases}

Where the Reserve Bank is the lessee, the lease rentals payable on operating leases are recognised in the Statement of Financial Performance over the term of the lease on a basis consistent with the expected benefits derived from the leased assets.

\section{Finance Leases}

Assets under finance leases are recognised as fixed assets in the Statement of Financial Position. Leased assets are recognised initially at the lower of the present value of the minimum lease payments or their fair value. A corresponding liability is established and each lease payment is allocated between the liability and interest expense. Leased assets are depreciated on the same basis as equivalent property, plant and equipment.

\section{(I) Currency and Artwork Collections and Archives}

Items held in the Reserve Bank's currency and artwork collections and archives that have a material commercial value are independently valued at estimated market values. Revaluations are performed every five years. Surpluses of book value over historic cost for this class of asset are recorded in the Currency and Artwork Collections Revaluation Reserve. Nominal values have been placed on items with no material commercial value. Collections are not depreciated. Additions are held at cost until subsequent revaluations.

\section{(m) Inventories}

Inventories are carried at the lower of cost or realisable value. Cost is determined on a weighted average basis. Unissued currency stocks are recorded as inventory at the cost of acquisition and expensed when issued.

\section{(n) Accounts Receivable}

Accounts receivable are carried at expected realisable value after making due allowance for doubtful debts.

\section{(o) Provision for Transfer of Surplus}

The Reserve Bank's notional surplus income, as calculated under section 158 of the Reserve Bank of New Zealand Act 1989, is recorded in the Statement of Financial Performance as Provision for Transfer of Surplus. Under section 162 of the Act, the Minister of Finance directs whether the notional surplus income is paid to the Crown or credited to the Bank's reserves after having regard to the Bank's capital requirements and the views of the Board of Directors. As the full notional surplus is required to be paid to the Crown unless otherwise directed by the Minister of Finance, the full notional surplus is shown as a liability at balance date.

\section{(p) Provision for Restructuring}

A provision for restructuring is recognised only when the Reserve Bank has a detailed restructuring plan and the plan has either started to be implemented or has been communicated to those affected by it. Only those expenses that are necessarily entailed by the restructuring and are not associated with ongoing activities are included in the provision.

\section{(q) Retirement Gratuity}

Retirement gratuity liabilities are recorded at actuarial value. This is calculated by an independent actuary using a discounted cash flow model based on the relevant market yield curves. Changes in value are recognised in the Statement of Financial Performance as Personnel Expenses. Retirement gratuity liabilities are reported in the Statement of Financial Position as Accrued Employee Entitlements.

\section{(r) Personnel Expenses}

Personnel Expenses include the full cost of all staff benefits, including any applicable Fringe Benefit Tax. Salaries and leave accrued at year-end are reported in the Statement of Financial Position as Accrued Employee Entitlements.

\section{(s) Income Tax}

Section CB3 of the Income Tax Act 1994 exempts the Reserve Bank from income tax.

\section{(t) Custodial Activities}

Securities held by the Reserve Bank under custodial arrangements are not included in these financial statements (see note 44).

\section{(u) Segmental Reporting}

The Reserve Bank presents financial assets and financial liabilities, and their associated income and expense streams, by distinguishing between foreign currency and local currency activities. In addition, the Bank provides operating results by function. The Bank considers that these reporting approaches provide appropriate segmental reporting of the Bank's activities. 


\section{(v) Cost Allocation}

The Reserve Bank of New Zealand Act 1989 requires the Reserve Bank to account for revenue and expenses by reference to the functions the Bank performs. The Bank has systems in place to allocate costs to functions. Costs are allocated as closely as possible to reflect their consumption. Direct costs are assigned directly to functions. Indirect costs are allocated to functions based on pre-determined cost drivers and related activity/usage information.

\section{(w) Income Allocated Between Functions}

Each function receives income and incurs expenses relating directly to the assets and liabilities used exclusively by that function. These income and expenses are presented in the Statement of Cost of Services. Notional balance sheets are calculated for each of the Reserve Bank's functions as though each function operated autonomously. Income and expense flows are also attached to the notional funding for each function. This structure enables each function to more accurately report the financial outcome of the services provided.

The income earned from the assets funded by the Bank's net equity is allocated equally to the Foreign Reserves Management and Market Operations functions.

\section{(x) Cash Flows}

Cash is defined as those items that are convertible to cash within two working days and are used in the day-to-day cash management of the Reserve Bank. This definition includes local currency securities purchased under agreements to re-sell and a substantial portion of the Bank's foreign reserves portfolio (see note 2)

Investing activities include cash movements, including realised gains and losses, in the Bank's financial asset portfolios and cash flows arising from movements in fixed assets.

Financing activities include cash flows arising from the issue of circulating currency, borrowing from the Treasury, and payment of the net operating surplus to the Crown.

Operating activities include income and expenditure cash flows not included in investing or financing activities.

\section{(y) Comparative Amounts}

To ensure consistency with the current year, comparative figures have been restated where appropriate.

\section{(z) Changes in Accounting Policies}

The Bank now reports its forward foreign exchange swap contracts at fair value. Previously, the Bank reported the contracts at yield to maturity. The Bank changed its accounting treatment of these contracts to ensure all derivative instruments were accounted for on a fair value basis. This change in accounting policy decreased Derivatives in a Gain Position in the Statement of Financial Position by $\$ 0.1$ million and decreased Other Foreign Currency Income in the Statement of Financial Performance by $\$ 0.1$ million.

This change does not affect the Cash Flow Statement.

There have been no other material changes to the Reserve Bank's accounting policies for the year ended 30 June 2003 and uniform accounting policies have been applied throughout the Bank. 


\section{Consolidated Statement of Financial Position}

As at 30 June $\quad$ Note $\begin{array}{rr}2003 & 2002 \\ & \$ 000\end{array}$

\section{Assets:}

Foreign Currency Financial Assets

Cash Balances with Other Central Banks

Other Cash Balances

$67,465 \quad 186,025$

Marketable Securities

$1,738 \quad 6,223$

Marketable Securities

$2 \quad 3,276,974 \quad 2,822,359$

Short-Term Advances

$42,540 \quad 348,361$

Receivable from Unsettled Sales of Securities

$43,195 \quad 24,725$

Securities Purchased Under Agreements to Re-sell

$2,759,011$

$2,194,682$

Accrued Interest

$24,728 \quad 24,052$

Total Foreign Currency Financial Assets ${ }^{1}$

$6,215,651 \quad 5,606,427$

Local Currency Financial Assets

Cash on Hand

Securities Purchased Under Agreements to Re-sell

Investment Portfolio - NZ Government Securities

Accrued Interest

Other Local Currency Financial Assets

Total Local Currency Financial Assets

Total Financial Assets

$2,120,364 \quad 2,818,939$

$3,242,673 \quad 2,953,554$

$57,199 \quad 48,233$

4

\begin{tabular}{rr}
9,876 & 8 \\
\hline $5,430,116$ & $5,820,738$ \\
\hline $11,645,767$ & $11,427,165$
\end{tabular}

Other Assets

Accounts Receivable

Inventories

\begin{tabular}{rrr} 
& 2,051 & 2,413 \\
5 & 7,562 & 5,709 \\
6 & 28,694 & 29,968 \\
\hline 38,307 & 38,090 \\
\hline $11,684,074$ & $11,465,255$ \\
\hline
\end{tabular}

Fixed Assets

Total Other Assets

Total Assets

$11,684,074 \quad 11,465,255$ 


\section{Liabilities:}

Foreign Currency Financial Liabilities

Short-Term Deposits

Payable for Unsettled Purchases of Securities

Short Sales of M arketable Securities

Derivative Instruments in a Loss Position

Securities Sold Under Agreements to Repurchase

Term Liabilities

Accrued Interest

Total Foreign Currency Financial Liabilities ${ }^{1}$

Local Currency Financial Liabilities

Government Deposits

Other Deposits

Accrued Interest

Total Local Currency Financial Liabilities

Total Financial Liabilities

Other Liabilities

Currency in Circulation

Provision for Transfer of Surplus

Miscellaneous Liabilities

Total Other Liabilities

Total Liabilities

Equity

Total Liabilities and Equity

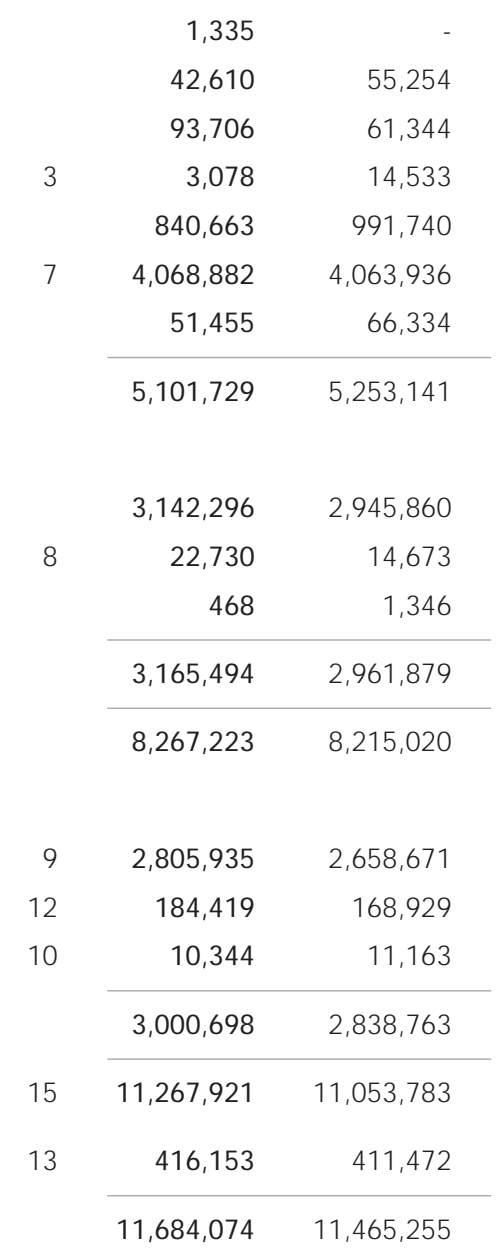

The above statement is to be read in conjunction with the notes on pages 66 to 100 . 


\section{Consolidated Statement of Movements in Equity}

\begin{tabular}{|c|c|c|c|}
\hline For the year ended 30 June & Note & $\begin{array}{l}2003 \\
\$ 000\end{array}$ & $\begin{array}{l}2002 \\
\$ 000\end{array}$ \\
\hline Net Surplus for the Year & & 189,100 & 175,006 \\
\hline Total Recognised Revenues and Expenses for the Year & & 189,100 & 175,006 \\
\hline Provision for Transfer of Surplus to Government & 12 & $(184,419)$ & $(168,929)$ \\
\hline Movements in Equity for the Year & & 4,681 & 6,077 \\
\hline Equity at Start of Year & & 411,472 & 405,395 \\
\hline Equity at End of Year & 13 & 416,153 & 411,472 \\
\hline
\end{tabular}

The above statement is to be read in conjunction with the notes on pages 66 to 100 . 


\section{Consolidated Statement of Cost of Services}

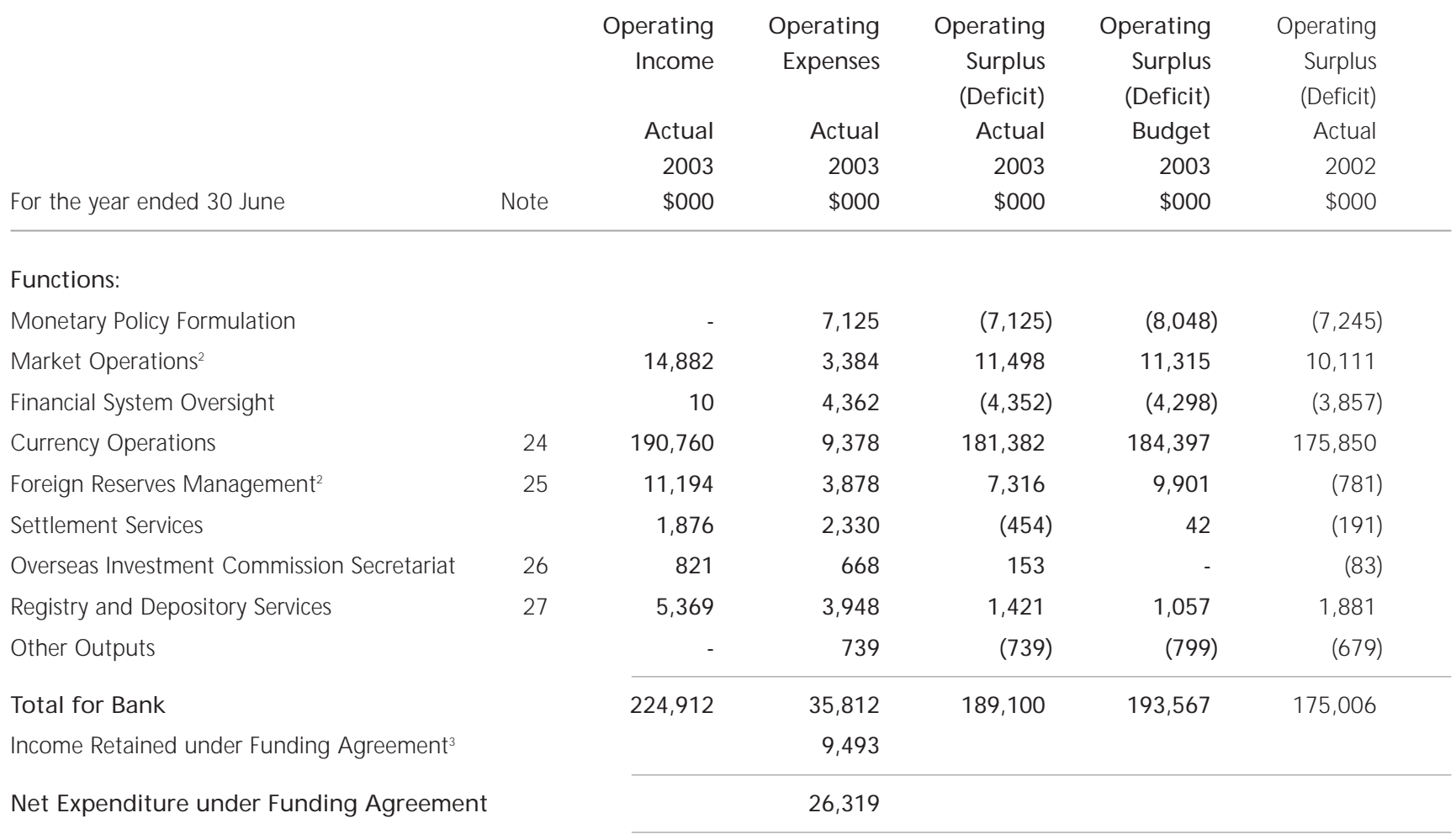

The Consolidated Statement of Cost of Services shows the total cost of providing each function, including internal transfers between functions.

The above statement is to be read in conjunction with the notes on pages 66 to 100 .

The income for Market Operations and Foreign Reserves Management includes an allocation of $\$ 16.8$ million (2002 $\$ 13.3$ million) in income earned from the assets funded by the Bank's net equity.

3 The Funding Agreement commencing 1 July 2000 allows the Bank to retain revenue from specified revenue-generating activities and net this revenue against expenses for the calculation of Net Expenditure under Funding Agrement. 


\section{Consolidated Statement of Financial Performance}

$\begin{array}{lrrrr} & & \text { Actual } & \text { Budget } & \text { Actual } \\ \text { For the year ended } 30 \text { June } & & 2003 & 2003 & 2002 \\ & \text { Note } & \$ 000 & \$ 000 & \$ 000\end{array}$

Operating Income:

Income from Foreign Currency Financial Assets

Interest Income

$28108,731 \quad 166,891$

Gain from Market Value Changes

30

28,192

10,326

Other Foreign Currency Income

50,227

17,814

Total Income from Foreign Currency Financial Assets

187,150

195,031

Expenses on Foreign Currency Financial Liabilities

Interest Expense

29

141,216

159,060

Loss from Market Value Changes

30

51,342

46,760

Other Foreign Currency Expenses

560

945

Total Expenses on Foreign Currency Financial Liabilities

Net Foreign Exchange Revaluation Gain

193,118

206,765

Foreign Currency Investment Income (Loss)

31

487

1,530

Income from Local Currency Financial Assets

Interest Income

$(5,481)$

$(10,204)$

28

386,251

323,079

Liquidity M anagement Swap Income

39,913

5,204

Gain from Market Test Activities

70

86

Total Income from Local Currency Financial Assets

426,234

328,369

Total Expenses on Local Currency Financial Liabilities

29

205,149

117,461

Local Currency Investment Income

Net Investment Income

Other Income

Total Operating Income

\begin{tabular}{rrr}
\hline 221,085 & & 210,908 \\
\hline 215,604 & 220,973 & 200,704 \\
9,308 & 8,981 & 10,334 \\
\hline 224,912 & 229,954 & 211,038 \\
\hline
\end{tabular}




\begin{tabular}{|c|c|c|c|c|}
\hline For the year ended 30 June & Note & $\begin{array}{r}\text { Actual } \\
2003 \\
\$ 000\end{array}$ & $\begin{array}{r}\text { Budget } \\
2003 \\
\$ 000\end{array}$ & $\begin{array}{r}\text { Actual } \\
2002 \\
\$ 000\end{array}$ \\
\hline \multicolumn{5}{|l|}{ Operating Expenses: } \\
\hline Personnel & & 15,635 & 16,031 & 15,588 \\
\hline Asset Management & 33 & 3,992 & 4,046 & 4,992 \\
\hline New Currency Issued & 24 & 6,041 & 4,438 & 4,720 \\
\hline Administration & & 1,041 & 1,360 & 1,073 \\
\hline Other & 34 & 9,103 & 10,512 & 9,299 \\
\hline Total Operating Expenses & & 35,812 & 36,387 & 35,672 \\
\hline Loss on Revaluation or Disposal of Bank Properties & & - & - & 360 \\
\hline Total Expenses & & 35,812 & 36,387 & 36,032 \\
\hline Surplus Available for Appropriation & 12 & 189,100 & 193,567 & 175,006 \\
\hline
\end{tabular}

The above statement is to be read in conjunction with the notes on pages 66 to 100 .

The Reserve Bank's operating expenditure was $\$ 35.8$ million, which was 1.6 per cent below budget. In particular:

- Personnel expenses were $\$ 0.4$ million less than budgeted, mainly due to staff departures. Personnel expenses included $\$ 0.9$ million in superannuation contributions to staff's defined contribution superannuation schemes.

- Costs of issuing new coins and bank notes were \$1.6 million more than budgeted, mainly due to higher-than-expected demand.

- Administration expenses were $\$ 0.3$ million less than budget, mainly due to lower-than-expected communications expenses, postage costs and stationery purchases.

- Other expenses were $\$ 1.4$ million less than budgeted, mainly due to reduced professional services and computer expenses. 


\section{Consolidated Statement of Cash Flows}

$\begin{array}{lrr}\text { For the year ended } 30 \text { June } & \text { Note } & 2003 \\ \$ 000 & \$ 000\end{array}$

Cash Flows From Operating Activities:

Source:

Interest Received - Foreign Currency

$$
\begin{aligned}
\text { - Local Currency } & \text { - Investment Portfolio } \\
& \text { - Other }
\end{aligned}
$$

Liquidity Management Swap Income

Fees, Commission and Other Income Received

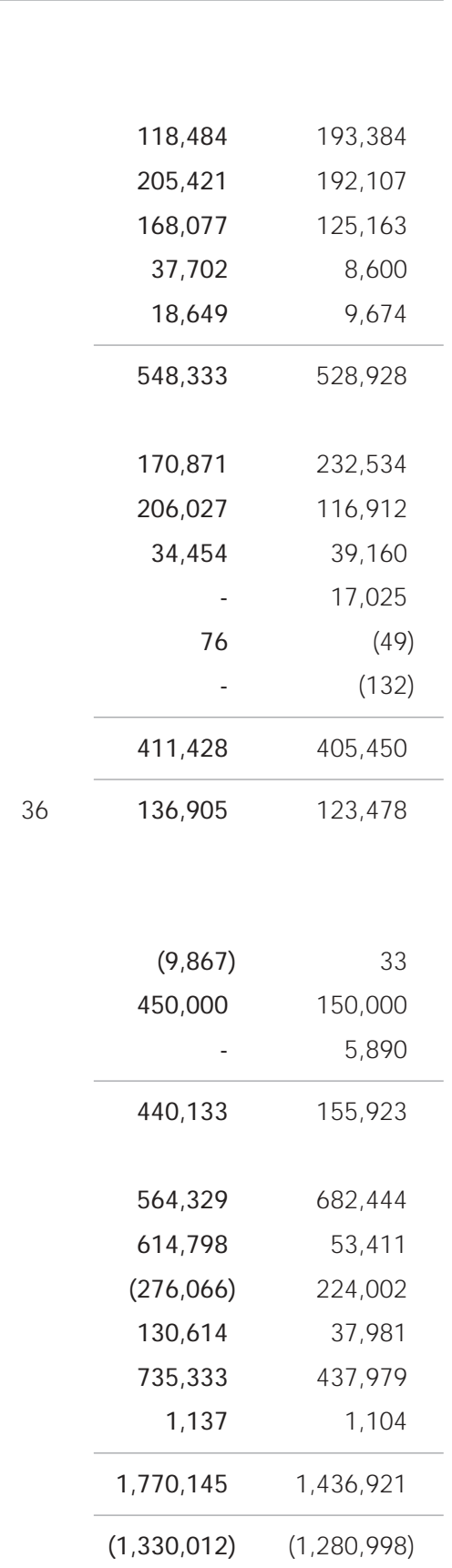

Disbursements:

$\begin{array}{ll}\text { Interest Paid } & \text { - Foreign Currency } \\ & \text { - Local Currency }\end{array}$

Payments to Suppliers and Employees

Other Foreign Currency Expenses

Net GST Paid (Received)

Income Tax Paid (Received)

Net Cash Flow From Operating Activities

Cash Flows From Investing Activities:

Source:

Net (Increase) Decrease in Other Local Currency Financial Assets

Maturity of New Zealand Government Securities for Investment Portfolio

Sale of Fixed Assets

Disbursements:

Net Increase (Decrease) in Foreign Currency Securities Purchased under Agreements to Re-sell

Net Increase (Decrease) in Foreign Currency Marketable Securities

Net Increase (Decrease) in Other Foreign Currency Financial Assets

Net (Increase) Decrease in Other Foreign Currency Financial Liabilities

Purchases of NZ Government Securities for Investment Portfolio

Purchase of Fixed Assets

Net Cash Flow From Investing Activities 
For the year ended 30 June

Cash Flows From Financing Activities:

Source:

Issue of Circulating Currency

$1,584,121 \quad 1,359,937$

Withdrawal of Circulating Currency

$1,436,857 \quad 1,164,003$

Net Issue of Circulating Currency

\begin{tabular}{rr}
\hline 147,264 & 195,934 \\
799,421 & $1,217,532$ \\
\hline 946,685 & $1,413,466$
\end{tabular}

Disbursements:

Payment for Demonetised Currency

$34 \quad 13$

Repayment of Foreign Currency Term Liabilities

$358,086 \quad 1,187,251$

Payment of Surplus to Government

$168,929 \quad 154,138$

Net Cash Flow From Financing Activities

CASH FLOW FROM ALL ACTIVITIES

Plus Exchange Rate Effect

\begin{tabular}{rr}
34 & 13 \\
358,086 & $1,187,251$ \\
168,929 & 154,138 \\
\hline 527,049 & $1,341,402$ \\
\hline 419,636 & 72,064 \\
\hline$(773,471)$ & $(1,085,456)$ \\
$(141,830)$ & $(330,948)$ \\
\hline$(915,301)$ & $(1,416,404)$ \\
$1,582,988$ & $2,999,392$ \\
\hline 677,687 & $1,582,988$
\end{tabular}

NET CASH FLOW FROM ALL ACTIVITIES

Opening Cash Balance

CLOSING CASH BALANCE

The above statement is to be read in conjunction with the notes on pages 66 to 100.

Cash is defined in the Statement of Cash Flows as those items that are convertible to cash within two working days and are used in the day-today cash management of the Reserve Bank. This definition includes local currency securities purchased under agreements to re-sell and a substantial portion of the Bank's foreign reserves portfolio (see note 2).

Cash movements in some portfolios have been presented net as this is considered to provide a fairer presentation of the movements in the Bank's cash profile.

For further information on the management of the Bank's liquidity, see note 22. 


\section{Nature and Extent of Activities}

The Reserve Bank's role as a central bank determines the nature and extent of its activities with respect to financial instruments. This role is defined by the Reserve Bank of New Zealand Act 1989.

\section{(a) Foreign Currency Activities}

Foreign currency activities result mainly from the Bank's holdings of foreign currency assets under its foreign reserves management function. The foreign reserves management portfolio comprises foreign currency assets held for foreign exchange intervention purposes ("foreign reserves"), pursuant to section 24 of the Act, and other foreign currency assets held for trading purposes. The level of foreign reserve intervention assets is determined by the M inister of Finance on advice from the Bank. The funding for foreign reserves is provided by foreign currency loans from the Treasury. These loans incur interest at market rates. Generally these loans are held to maturity, though from timeto-time the opportunity to repay early may be taken at the instigation of either the Bank or the Treasury, where this is expected to reduce the cost of funding. Funding for other foreign currency assets held for trading purposes usually arises through repurchase transactions with foreign securities trading firms.

Foreign currency assets are held in various currencies. The majority are denominated in United States dollars and euros. Financial instruments held within these foreign currency portfolios consist mainly of sovereign securities, securities held under reverse-repurchase transactions or balances held with other central banks, commercial banks, highly rated corporates and settlement institutions. Liquidity and credit risk are key criteria in determining the type of instruments held.

The foreign reserves portfolio is actively managed. Subject to liquidity and credit risk constraints, the Bank defines benchmark portfolios that represent a "neutral" asset and liability structure in terms of market risk. The neutral position is established to minimise the Bank's exposure to foreign currency risk and interest rate risk. In general, liquidity and credit risk constraints mean that the neutral structure will return a loss - the returns on assets will be less than the cost of funding those assets.

Departures of the actual asset and liability portfolio from the neutral asset and liability structure are undertaken within defined risk boundaries where there is an expected increase in returns. Departures from the neutral structure also arise when the Bank trades in the foreign exchange markets on its own account and when marketable securities are short sold, again for expected return enhancement, within defined risk boundaries. Departures from the neutral structure involve discretionary trading and portfolio management decisions undertaken by specialist staff with delegated authority from the Governor.

The Bank also holds, from time-to-time, foreign currency assets and liabilities that arise from market operations. Any foreign currency exposures related to market operations are fully hedged through the use of forward foreign exchange swap contracts.

For further information on the risk management policies relating to financial instruments, see notes 16 to 22 .

\section{(b) Events during 2002/03}

- In October 2002, the Bank closed the operation of the quantitative rule-based trading strategies previously undertaken in the foreign reserves portfolio as these previously profitable strategies became less successful.

- In June 2003, the Bank announced that it would be investing US \$25 million in the newly created EMEAP4- Bank for International Settlements Asian Bond Fund. The investment in the Asian Bond Fund will occur over the first quarter of the 2003/04 financial year.

- The Bank has entered into two new foreign currency loans for US \$181 million from the Treasury that will be drawn in early July 2003. These loans largely replace maturing loans with the Treasury.

- In June 2003, the Bank received an invitation to become a shareholder of the Bank for International Settlements for an investment of $\$ 100$ million. The Bank accepted the invitation in August 2003.

\section{(c) Derivative Instruments}

The Bank's involvement in derivative instruments comprises forward foreign exchange swap contracts, interest rate futures and interest rate swaps. Forward foreign exchange swap contracts are used as a part of hedged foreign exchange transactions for both market operations and foreign reserves management. Any unrealised foreign exchange gain (loss) on unsettled forward foreign exchange swap contracts is offset by the foreign exchange revaluation on the associated money market instruments. Interest rate futures and interest rate swaps are used to enhance expected returns on foreign currency assets and, from time-to-time, to hedge interest rate and foreign exchange risk. 


\section{(d) Securities Lending Programme}

As part of its foreign reserves operations, the Bank participates in a securities lending programme managed by JPM organ Chase Bank. Under the programme, JPM organ Chase Bank lends out securities owned by the Bank in exchange for cash or alternative securities. The range of financial assets that can be acquired under the programme is constrained by guidelines compatible with those that apply to the Bank's own foreign currency asset portfolios.

As at 30 June 2003, the market value of securities lent out under the programme was US $\$ 399.6$ million (2002 US $\$ 440.5$ million).

\section{(e) Foreign Exchange Gains and Losses}

Section 17 and 18 of the Act provide for the M inister of Finance to direct the Bank to deal in foreign exchange or for the M inister of Finance to fix the foreign exchange rates for foreign exchange dealing by the Bank. Section 21 of the Act requires the Bank to either pay any foreign currency exchange gains to the Crown or to be reimbursed for any foreign exchange losses as a result of dealing in foreign exchange under sections 17 or 18 of the Act. For the year to 30 June 2003, there have been no payments to or from the Crown under section 21 of the Act (2002 nil).

\section{(f) Restrictions on Title to Assets}

As part of the active management of its foreign currency operations, the Bank enters into security repurchase transactions. The securities sold by the Bank under repurchase agreements continue to be recorded as Marketable Securities in the Bank's Statement of Financial Position. At balance date, securities with a book value of $\$ 840.7$ million (2002 $\$ 991.7$ million) had been sold to counterparties under repurchase agreements. The fair value of these securities was $\$ 828.3$ million (2002 $\$ 999.8$ million). These transactions are also recognised as a liability for Securities Sold under Agreements to Repurchase in the Bank's Statement of Financial Position.

The Bank also purchases securities under reverse-repurchase agreements in both its foreign currency and local currency operations. These transactions are recognised as Securities Purchased under Agreements to Re-sell in the Bank's Statement of Financial Position.

The Bank can be required to deliver collateral under interest rate swap arrangements. Any collateral delivered by the Bank remains in the Statement of Financial Position. At balance date, collateral delivered by the Bank was \$nil (2002 \$nil).

\section{(g) Local Currency Activities}

Local currency activities arise as a result of:

- The Bank's liquidity management that largely involves offsetting the daily net flows to or from government by advancing funds to or withdrawing funds from the banking system. This is done mostly through daily open market operations. Any residual banking system liquidity is advanced or withdrawn using the Official Cash Rate scheme (OCR). Under the OCR scheme, the Bank advances or withdraws cash at a margin to the OCR. The financial instruments used in these operations include local currency reverse-repurchase transactions and forward foreign exchange swap contracts. The Bank periodically uses securities from its investment portfolio of New Zealand government securities in repurchase transactions, to withdraw funds from the banking system, for liquidity management purposes.

- The Bank's investment portfolio of New Zealand government bonds supports its liability for currency in circulation and the Bank's net equity. The Bank holds these investments until maturity. The Bank purchases bonds for the investment portfolio if the amount of currency in circulation increases or if one of the Bank's current holdings matures. The Bank only purchases those government bonds that are currently being tendered by the Crown. However, the Bank manages this process to maintain a relatively even holding of each bond maturity where possible.

From time-to-time, the Bank may also hold small trading positions in Crown or registered bank securities as part of market test activities. 


\section{Asset Notes}

\section{Foreign Currency Marketable Securities}

\begin{tabular}{|c|c|c|c|}
\hline & & 2003 & 2002 \\
\hline & Note & $\$ 000$ & $\$ 000$ \\
\hline \multicolumn{4}{|l|}{ Marketable Securities } \\
\hline - Liquifiable within two days (considered cash equivalent) & 37 & $1,643,142$ & $1,532,330$ \\
\hline - Liquifiable outside two days (not considered cash equivalent) & & $1,553,038$ & $1,237,501$ \\
\hline Derivative Instruments in a Gain Position & 3 & 80,794 & 52,528 \\
\hline Total Marketable Securities & & $3,276,974$ & $2,822,359$ \\
\hline
\end{tabular}

3. Derivative Instruments

$\begin{array}{rrrr}\text { Book } & \text { Notional } & \text { Book } & \text { Notional } \\ \text { Value } & \text { Principal } & \text { Value } & \text { Principal } \\ 2003 & 2003 & 2002 & 2002 \\ \$ 000 & \$ 000 & \$ 000 & \$ 000\end{array}$

Interest Rate Futures

Futures in a Gain Position

Net Futures Position

\begin{tabular}{llll}
2,117 & 122,173 & 2,384 & 291,941 \\
\hline 2,117 & 122,173 & 2,384 & 291,941
\end{tabular}

At 30 June 2003, the Bank had 530 open futures contracts (2002 441).

Interest Rate Swaps

Swaps in a Gain Position

\begin{tabular}{rrrr}
61,989 & 657,104 & 29,722 & 791,352 \\
$(3,078)$ & 186,136 & $(1,263)$ & 101,562 \\
\hline 58,911 & 843,240 & 28,459 & 892,914 \\
& & & \\
16,688 & $1,098,923$ & 20,422 & 506,500 \\
- & - & $(13,270)$ & 112,917 \\
\hline 16,688 & $1,098,923$ & 7,152 & 619,417 \\
80,794 & $1,878,200$ & 52,528 & $1,589,793$ \\
$(3,078)$ & 186,136 & $(14,533)$ & 214,479 \\
\hline 77,716 & $2,064,336$ & 37,995 & $1,804,272$ \\
\hline
\end{tabular}

4. Other Local Currency Financial Assets

\begin{tabular}{lrr} 
& 2003 & 2002 \\
& $\$ 000$ & $\$ 000$ \\
\hline Advances to Staff & - & 4 \\
Other Financial Assets & 9,876 & 4 \\
Total Other Local Currency Financial Assets & 9,876 & 8
\end{tabular}




\section{Inventories}

\begin{tabular}{lrr} 
& 2003 & 2002 \\
& $\$ 000$ & $\$ 000$ \\
\hline Bank Notes for Circulation & 4,315 & 3,567 \\
Coin for Circulation & 3,149 & 1,711 \\
Collectors' Currency & 87 & 424 \\
Stationery & 11 & 7 \\
Total Inventories & 7,562 & 5,709 \\
\hline
\end{tabular}

\section{Fixed Assets}

Land \& Computer

Total Buildings Improvements

$\$ 000 \$ 000$
Hardware \&

Software

$\$ 000$
Currency \&

Plant \& Art

Equipment Collection

$\$ 000 \$ 000$

As at 30 June 2002

\begin{tabular}{|c|c|c|c|c|c|c|}
\hline Cost & 40,728 & 25,065 & 4,624 & 6,951 & 3,326 & 762 \\
\hline Accumulated depreciation & 10,760 & 454 & 2,541 & 4,873 & 2,892 & - \\
\hline Net book amount & 29,968 & 24,611 & 2,083 & 2,078 & 434 & 762 \\
\hline \multicolumn{7}{|l|}{ Year ended 30 June 2003} \\
\hline Opening net book amount & 29,968 & 24,611 & 2,083 & 2,078 & 434 & 762 \\
\hline Additions & 1,136 & - & - & 621 & 506 & 9 \\
\hline Disposals at book amount & - & - & - & - & - & - \\
\hline Depreciation & 2,410 & 427 & 515 & 1,262 & 206 & - \\
\hline Closing net book amount & 28,694 & 24,184 & 1,568 & 1,437 & 734 & 771 \\
\hline \multicolumn{7}{|l|}{ As at 30 June 2003} \\
\hline Cost & 40,569 & 25,065 & 4,108 & 7,013 & 3,612 & 771 \\
\hline Accumulated depreciation & 11,875 & 881 & 2,540 & 5,576 & 2,878 & - \\
\hline Net book amount & 28,694 & 24,184 & 1,568 & 1,437 & 734 & 771 \\
\hline
\end{tabular}

The Bank owns its head office in Wellington and leases out seven of the fourteen floors to tenants under operating leases.

The book values for land and buildings (comprising the Wellington Head Office and Wellington Carparks) are depreciated market values based on existing use with the exception of the Wellington specialised basement and ground floor occupied by the Reserve Bank, which are valued at depreciated replacement cost. The market value of the Bank's land and buildings to a purchaser not requiring the Bank's specialised facilities was assessed at $\$ 23.6$ million at the last valuation date. The book value of the land and buildings would have been $\$ 7.1$ million (2002 \$7.2 million) if the Bank had recorded these using historic cost less depreciation.

\section{Valuation Date}

Wellington Head Office

Wellington Carparks
June 2001

June 1999
Registered Valuer Jones Lang Lasalle Advisory Limited

Darroch Limited

Computer hardware and software includes computer hardware, which cost $\$ 390,000$ less the accumulated depreciation of $\$ 92,000$, which is leased under a finance lease. 


\section{Liability and Equity Notes}

\section{Term Liabilities}

The funding for foreign reserves is provided by foreign currency loans from the Treasury. These loans are unsecured and incur interest at market rates. The weighted average interest rates do not include the impact of the Bank's interest rate swaps.

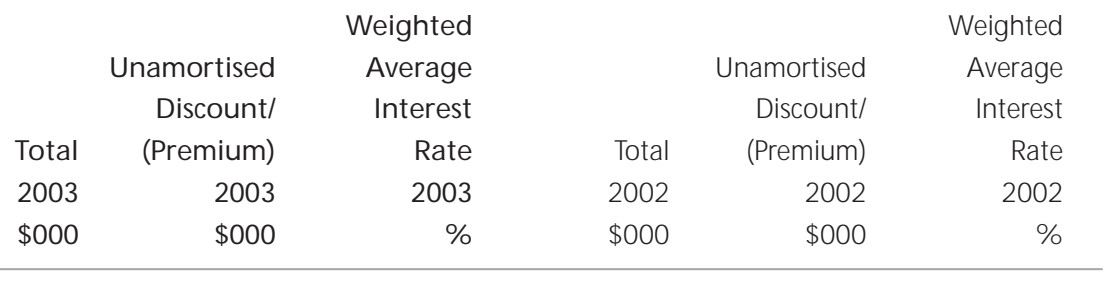

Unsecured Term Liabilities

\begin{tabular}{lrrrrrr} 
One year or less & 646,440 & - & $1.7 \%$ & 415,316 & $(193)$ & $1.4 \%$ \\
Between one and two years & 635,867 & - & $1.8 \%$ & 727,244 & - & $2.8 \%$ \\
Between two and five years & $2,105,156$ & $(29,063)$ & $2.1 \%$ & $2,369,947$ & $(57,386)$ & $3.4 \%$ \\
Over five years & 681,419 & - & $1.8 \%$ & 551,429 & - & $2.9 \%$ \\
\cline { 2 - 7 } Total Unsecured Term Liabilities & $4,068,882$ & $(29,063)$ & & $4,063,936$ & $(57,579)$
\end{tabular}

\section{Other Deposits}

\begin{tabular}{lrr} 
& 2003 & 2002 \\
& $\$ 000$ & $\$ 000$ \\
\hline Settlement Bank Deposits & 1,815 & 4,387 \\
Central Bank Deposits & 13,625 & 1,917 \\
International M onetary Fund Deposits & 6,963 & 8,163 \\
Other Deposits & 327 & 206 \\
Total Other Deposits & 22,730 & 14,673
\end{tabular}

\section{Currency in Circulation}

The exclusive rights of national currency issue are vested with the Reserve Bank. Currency in circulation comprises bank notes and coins issued by the Reserve Bank and does not include coin issued by the Treasury prior to July 1989 (see note 42 (b)).

As at 30 June 2003, the following bank notes and coins were in circulation.

\begin{tabular}{|c|c|c|c|c|}
\hline Denomination & $\begin{array}{r}\text { Number of } \\
\text { Note Forms/Coins } \\
2003 \\
000\end{array}$ & $\begin{array}{r}\text { Face } \\
\text { Value } \\
2003 \\
\$ 000\end{array}$ & $\begin{array}{r}\text { Number of } \\
\text { Note Forms/Coins } \\
2002 \\
000\end{array}$ & $\begin{array}{r}\text { Face } \\
\text { Value } \\
2002 \\
\$ 000\end{array}$ \\
\hline $5 c$ & 249,240 & 12,462 & 225,460 & 11,273 \\
\hline $10 c$ & 80,210 & 8,021 & 70,170 & 7,017 \\
\hline $20 c$ & 25,225 & 5,045 & 20,375 & 4,075 \\
\hline $50 c$ & 8,078 & 4,039 & 5,086 & 2,543 \\
\hline$\$ 1$ & 57,329 & 57,329 & 53,614 & 53,614 \\
\hline$\$ 2$ & 56,176 & 112,352 & 52,730 & 105,460 \\
\hline$\$ 5$ & 16,220 & 81,102 & 15,290 & 76,450 \\
\hline$\$ 10$ & 15,653 & 156,531 & 15,730 & 157,304 \\
\hline$\$ 20$ & 50,639 & $1,012,786$ & 51,094 & $1,021,879$ \\
\hline$\$ 50$ & 8,428 & 421,384 & 6,588 & 329,378 \\
\hline$\$ 100$ & 9,349 & 934,884 & 8,897 & 889,678 \\
\hline Total Currency in Circulation & 576,547 & $2,805,935$ & 525,034 & $2,658,671$ \\
\hline
\end{tabular}


10. M iscellaneous Liabilities

\begin{tabular}{lrr} 
& 2003 & 2002 \\
& Note & $\$ 000$ \\
\hline Accounts Payable & 4,774 & 6,835 \\
Accrued Employee Entitlements & 3,186 & 2,587 \\
Other Current Liabilities & 913 & 605 \\
Demonetised Currency & 1,171 & 1,136 \\
Capitalised Lease Obligations (unsecured) & 38 & 300 \\
Total Miscellaneous Liabilities & 10,344 & 11,163
\end{tabular}

Demonetised currency is recognised as a contingent liability (see note 42(c)) except for $\$ 1.2$ million (2002 \$1.1 million), which has been retained to cover future expected redemptions.

Pre-decimal coin was issued by the Treasury and is included in the Reserve Bank's contingent liabilities (see note 42(b)).

\section{Provision for Restructuring}

20032002

$\$ 000 \quad \$ 000$

Registry and Depository Services

Balance at Start

Less Expenses Incurred

$-\quad 130$

Unused Balance Written Back

(99)

Total Provision for Restructuring

During 1999/2000, the Reserve Bank provided for restructuring RBNZ Registry Limited. This included provision for payments to staff who would be made redundant as a result of the out-sourcing of registry processing activities. Payments relating to out-sourcing of registry processing activities were completed during the 2001/02 financial year. 


\section{Transfers to Retained Earnings and Provision for Transfer of Surplus}

Under section 162 of the Reserve Bank of New Zealand Act 1989, the Reserve Bank's surplus, after any transfers to or from Equity, is paid to the Crown.

Transfers to or from the Bank's Equity reflect the difference between actual net expenditure and the level of net expenditure specified under the Funding Agreement with the Crown. Under-spending by the Bank in relation to the Funding Agreement results in a transfer to Equity. Over-spending by the Bank results in a transfer from Equity. In the current year, under-expenditure by the Bank of $\$ 4.7$ million (2002 $\$ 6.1$ million) has consequently been transferred to the Bank's Equity.

The Minister of Finance may authorise additional transfers to Equity. In the year under review, no additional transfers were made and the Bank's surplus, net of the transfers noted above, has been recorded in the Provision for Transfer of Surplus.

Total Expenses

$35,812 \quad 36,032$

Income Retained under Funding Agreement

9,493

Net Expenditure under Funding Agreement

$26,319 \quad 24,923$

Funding Level specified in Funding Agreement

$31,000 \quad 31,000$

Funding Agreement Under-Expenditure

Surplus Available for Appropriation

Less Transfers to Equity

Funding Agreement Under-Expenditure

4,681

6,077

Provision for Transfer of Surplus

184,419

168,929

13. Equity

Retained Earnings

Transfers to Retained Earnings

4,681

Transfer to Properties Revaluation Reserve

- $\quad(15,671)$

Movements in Retained Earnings for the Year

$4,681 \quad(9,594)$

Opening Balance

Closing Balance

395,105

404,699

Properties Revaluation Reserve

Transfer from Retained Earnings

15,671

Movements in Properties Revaluation Reserve

15,671

Opening Balance

Closing Balance

\begin{tabular}{rr}
- & 15,671 \\
- & 15,671 \\
\hline 15,671 & - \\
\hline 15,671 & 15,671
\end{tabular}

Currency and Artwork Collections Revaluation Reserve Opening Balance

\begin{tabular}{rr}
696 & 696 \\
\hline 696 & 696 \\
\hline 416,153 & 411,472
\end{tabular}

Closing Balance

Total Equity 


\section{Fair Value of Financial Instruments}

The fair value of a financial instrument is the amount for which an asset could be exchanged, or a liability settled, between knowledgeable, willing parties in an arms-length transaction.

Quoted market values represent fair value when a financial instrument is traded in an organised and liquid market that is able to absorb a significant transaction without moving the price against the trader.

\section{Derivative Instruments}

Where quoted market prices for derivative instruments are unavailable, the fair value is calculated using discounted cash flow models based on current interest rates for the type and maturity of the underlying instrument. The fair value of all derivative instruments is presented in note 3 .

\section{Financial Assets and Liabilities}

All other financial assets and liabilities are valued at either quoted market prices or prices derived from market yield curves, as described in the Reserve Bank's accounting policies, except as detailed below.

\section{Repurchase and Reverse-Repurchase Agreements}

The carrying value of repurchase and reverse-repurchase agreements is considered to approximate their fair value due to the short-term nature of the agreements.

Unsettled Transactions

The carrying value of unsettled sales and purchases is considered to approximate their fair value due to the very short term until settlement occurs.

\section{Short-Term Advances}

The carrying value of Short-Term Advances is considered to approximate their fair value due to the short term until maturity.

\section{Investment Portfolio - NZ Government Securities}

The fair value of the Bank's Investment Portfolio - NZ Government Securities is $\$ 3.47$ billion (2002 $\$ 3.01$ billion). This has been calculated by valuing the current holdings at 30 June 2003 market prices.

\section{Short-Term Deposits}

The carrying values of deposits are considered to approximate their fair value as they are payable on demand.

\section{Currency in Circulation}

The fair value of Currency in Circulation is considered to be its face value as reported in the accounts.

\section{Provision for Transfer of Surplus}

The carrying value of the provision is considered to approximate its fair value due to the short period between balance date and expected payment date. 


\section{Concentrations of Funding}

The Reserve Bank's significant end-of-year concentrations of funding were as follows.

\begin{tabular}{|c|c|c|c|c|c|}
\hline As at 30 June 2003 & $\begin{array}{l}\text { Total } \\
2003 \\
\$ 000\end{array}$ & $\begin{array}{r}\text { New Zealand } \\
\text { Government } \\
\$ 000\end{array}$ & $\begin{array}{r}\text { New Zealand } \\
\text { Public } \\
\$ 000\end{array}$ & $\begin{array}{r}\text { Overseas } \\
\text { Securities } \\
\text { Trading Firms } \\
\$ 000\end{array}$ & $\begin{array}{l}\text { Other } \\
\$ 000\end{array}$ \\
\hline \multicolumn{6}{|l|}{ Foreign Currency Financial Liabilities } \\
\hline Short-Term Deposits & 1,335 & - & - & - & 1,335 \\
\hline Payable for Unsettled Purchases of Securities & 42,610 & - & - & 42,610 & - \\
\hline Short Sales of Marketable Securities & 93,706 & - & - & - & 93,706 \\
\hline Derivative Instruments in a Loss Position & 3,078 & - & - & 243 & 2,835 \\
\hline Securities Sold Under Agreements to Repurchase & 840,663 & - & - & 840,663 & - \\
\hline Term Liabilities & $4,068,882$ & $4,068,882$ & - & - & - \\
\hline Accrued Interest & 51,455 & 51,455 & - & - & - \\
\hline Total Foreign Currency Financial Liabilities & $5,101,729$ & $4,120,337$ & - & 883,516 & 97,876 \\
\hline \multicolumn{6}{|l|}{ Local Currency Financial Liabilities } \\
\hline Government Deposits & $3,142,296$ & $3,142,296$ & - & - & - \\
\hline Other Deposits & 22,730 & - & - & - & 22,730 \\
\hline Accrued Interest & 468 & 452 & 16 & - & - \\
\hline Total Local Currency Financial Liabilities & $3,165,494$ & $3,142,748$ & 16 & - & 22,730 \\
\hline Total Financial Liabilities & $8,267,223$ & $7,263,085$ & 16 & 883,516 & 120,606 \\
\hline \multicolumn{6}{|l|}{ Other Liabilities } \\
\hline Currency in Circulation & $2,805,935$ & - & $2,805,935$ & - & - \\
\hline Provision for Transfer of Surplus & 184,419 & 184,419 & - & - & - \\
\hline M iscellaneous Liabilities & 10,344 & - & - & - & 10,344 \\
\hline Total Other Liabilities & $3,000,698$ & 184,419 & $2,805,935$ & - & 10,344 \\
\hline Total Liabilities & $11,267,921$ & $7,447,504$ & $2,805,951$ & 883,516 & 130,950 \\
\hline
\end{tabular}


Comparative figures as at 30 June 2002 were as follows.

\begin{tabular}{|c|c|c|c|c|c|}
\hline As at 30 June 2002 & $\begin{array}{l}\text { Total } \\
2002 \\
\$ 000\end{array}$ & $\begin{array}{r}\text { New Zealand } \\
\text { Government } \\
\$ 000\end{array}$ & $\begin{array}{r}\text { New Zealand } \\
\text { Public } \\
\$ 000\end{array}$ & $\begin{array}{r}\text { Overseas } \\
\text { Securities } \\
\text { Trading Firms } \\
\$ 000\end{array}$ & $\begin{array}{l}\text { Other } \\
\$ 000\end{array}$ \\
\hline \multicolumn{6}{|l|}{ Foreign Currency Financial Liabilities } \\
\hline Payable for Unsettled Purchases of Securities & 55,254 & - & - & - & 55,254 \\
\hline Short Sales of Marketable Securities & 61,344 & - & - & - & 61,344 \\
\hline Derivative Instruments in a Loss Position & 14,533 & - & - & - & 14,533 \\
\hline Securities Sold Under Agreements to Repurchase & 991,740 & - & - & 991,740 & - \\
\hline Term Liabilities & $4,063,936$ & $4,063,936$ & - & - & - \\
\hline Accrued Interest & 66,334 & 66,334 & - & - & - \\
\hline Total Foreign Currency Financial Liabilities & $5,253,141$ & $4,130,270$ & - & 991,740 & 131,131 \\
\hline \multicolumn{6}{|l|}{ Local Currency Financial Liabilities } \\
\hline Government Deposits & $2,945,860$ & $2,945,860$ & - & - & - \\
\hline Other Deposits & 14,673 & - & - & - & 14,673 \\
\hline Accrued Interest & 1,346 & 1,332 & - & - & 14 \\
\hline Total Local Currency Financial Liabilities & $2,961,879$ & $2,947,192$ & - & - & 14,687 \\
\hline Total Financial Liabilities & $8,215,020$ & $7,077,462$ & - & 991,740 & 145,818 \\
\hline \multicolumn{6}{|l|}{ Other Liabilities } \\
\hline Currency in Circulation & $2,658,671$ & - & $2,658,671$ & - & - \\
\hline Provision for Transfer of Surplus & 168,929 & 168,929 & - & - & - \\
\hline M iscellaneous Liabilities & 11,163 & - & 1,136 & - & 10,027 \\
\hline Total Other Liabilities & $2,838,763$ & 168,929 & $2,659,807$ & - & 10,027 \\
\hline Total Liabilities & $11,053,783$ & $7,246,391$ & $2,659,807$ & 991,740 & 155,845 \\
\hline
\end{tabular}




\section{Risk Management Notes}

\section{Risk Management}

The Reserve Bank is involved in policy-orientated activities. Therefore, the Bank's risk management framework differs from the risk management frameworks for most other financial institutions. The main financial risks that the Bank is exposed to include credit risk on foreign currency reserves and interest rate risk on both foreign and local currency assets and liabilities. In the management of foreign reserves, minimising liquidity risk is the prime consideration in order to maintain an effective foreign exchange intervention capability. Policies for managing interest rate, credit, foreign currency and liquidity risk are outlined in notes 18 to 22 . Like most other central banks, the nature of the Bank's operations creates exposure to a range of operational risks and reputational risks.

Bank management seeks to ensure that strong and effective risk-analysis, management and control systems are in place for assessing, monitoring and managing risk exposure. A Risk M anagement Committee, comprising the Governors and senior management, is responsible for advising on the monitoring and management of all risks that the Bank faces. A Reserves Oversight Committee comprising Governors and senior management reviews the foreign reserves business strategy and portfolio structure. This review includes the appropriateness of risk-return trade-offs underlying the business strategy and portfolio structure. Specialist staff conduct the Bank's local currency, foreign currency reserves management and foreign exchange dealing operations in accordance with a clearly defined risk management framework including limits and delegated authorities set by the Governor. The risk management framework is subject to regular review by the Risk Management Committee.

The majority of the Bank's financial risks arise from the foreign reserves and financial market operations of the Bank's Financial Stability Department. Within this department, a Risk Unit is responsible for maintaining the Bank's financial risk management framework. A separate department of the Bank (Financial Services Group) operates independent risk reporting systems that monitor and report compliance with various risk limits and policies.

The Risk Assessment and Assurance Department (which includes Internal Audit) reports to the Governors and the Audit Committee of the Board of Directors on internal audit and related issues. A risk-based framework, which evaluates key business risks and internal controls, is used to determine the extent and frequency of internal audits conducted. All Bank departments are subject to periodic internal audit review.

From July 2003, the Bank will self-insure all property plant and equipment including the Bank's Wellington building.

The Bank is subject to annual external audit by the Office of the Controller and Auditor-General under the Public Audit Act 2001. Auditing arrangements are overseen by an Audit Committee comprising three of the Bank's non-executive directors, which meets regularly to monitor the financial reporting and audit functions within the Bank. The Committee also reviews the internal audit function and has direct access to the external auditor. The Committee reports to the Board of Directors on its activities.

The overall risk management framework is designed to strongly encourage the sound and prudent management of the Bank's risks. The Bank seeks to ensure the risk management framework is consistent with financial market best practice and it periodically engages external experts to assist in reviewing and modifying risk management practices and processes. 


\section{Operational Risk}

Operational risk is the risk of loss in both financial and non-financial terms resulting from human error and the failure of internal processes and systems.

Managing operational risk in the Bank is seen as an integral part of day-to-day operations and management, which includes explicit consideration of both the opportunities and the risks of all business activities. Operational risk management includes Bank-wide corporate policies which describe the standard of conduct required of staff, a number of mandated generic requirements (e.g. a project management template) and specific internal control systems designed around the particular characteristics of various Bank activities.

Compliance with corporate policies, generic requirements and departmental internal control systems are managed by:

- an induction programme for new employees, which makes them aware of the requirements;

- a quarterly management affirmation by each Head of Department that corporate policies and departmental internal control systems have been complied with; and

- an active internal audit function.

In addition, Heads of Departments are required to report to Governors any incidents that could adversely impact on the Bank. This is known as the Proactive Problem Management process. Its purpose is to notify senior management promptly of important unexpected issues and to provide them with an opportunity to give immediate advice.

The above policies and procedures for managing operational risk are reinforced by the requirements of section 165 of the Reserve Bank of New Zealand Act 1989, which requires the financial statements of the Bank to include a statement signed by the Governor and Deputy Chief Executive accepting responsibility for, among other things, the establishment and maintenance of a system of effective internal control within the Bank.

\section{Credit Risk}

Credit risk is the risk of loss arising from a counterparty to a financial contract failing to discharge its obligations.

\section{(a) Credit Risk Management}

Credit risk in the foreign currency portfolios is monitored and managed daily. End-of-day exposures are controlled through comprehensive individual counterparty and issuer credit limits. Exposure concentrations to geographical location are controlled by aggregate credit limits. Exposures against these limits are measured in credit-equivalent terms depending on the nature of the exposure. Individual credit limits are set on the basis of the rating of the counterparty or issuer. Aggregate credit limits are set on the basis of country ratings and views on the likelihood of a default of one entity affecting the credit worthiness of other entities. Limits are updated as necessary when new market information emerges, with all limits formally reviewed on an annual basis. The Governor's tolerance for foreign reserve credit risk is a maximum possible loss in the event of default of an $A A+$ rated non-sovereign counterparty/issuer of no more than $\$ 350$ million.

Credit risk in local currency portfolios is also monitored and managed daily. Intra-day and inter-day exposures are controlled through comprehensive individual counterparty and issuer limits. Exposures to the New Zealand government are not included in this credit framework. Most exposures arise under intra-day reverse-repurchase agreements entered into with settlement account holders as part of the real time gross settlement system. Securities that the Reserve Bank accepts under intra-day reverse-repurchase agreements include New Zealand government bonds, Treasury bills, and short-term paper issued by registered banks, local authorities and highly rated corporates. The securities are held in the Bank's name for the duration of the exposure and there is no charge for this intra-day liquidity. The exposures to the counterparty from whom securities are purchased under reverse-repurchase agreements are monitored daily and in certain cases are subject to formal limits. The Bank only accepts New Zealand government paper in its inter-day liquidity management operations. Credit exposures arising from securities purchased under agreements to re-sell (reverse-repurchase agreements) are classified according to the issuer of the security for credit exposure concentration purposes. This is consistent with the Bank's view of the substance of the credit exposure and internal risk management.

As part of the arrangements for using derivatives, the Bank manages credit risk by providing or receiving collateral as derivatives are revalued over time. This collateral is likely to take the form of cash or government securities. The collateral taken at balance date was \$nil (2002 \$nil).

The maximum loss that the Bank would suffer as a result of a security issuer defaulting is the value reported in the accounts. 
(b) Concentrations of Credit Exposure

The Bank's significant end-of-year concentrations of credit exposure by industry type were as follows.

$\begin{array}{lrr} & 2003 & 2002 \\ & \$ 000 & \$ 000 \\ \text { New Zealand Government } & 5,472,670 & 5,850,452 \\ \text { Other Sovereign Issuers (excluding New Zealand Government) } & 4,347,697 & 3,667,632 \\ \text { Supranational Financial Institutions } & 182,625 & 262,354 \\ \text { Foreign Banks } & 1,569,997 & 1,642,045 \\ \text { Other } & 72,778 & 4,682 \\ \text { Total Financial Assets } & 11,645,767 & 11,427,165\end{array}$

An alternative approach would be to classify credit exposures arising from securities purchased under agreements to re-sell according to the counterparty to the transaction. Using this approach would result in credit exposures of:

- $\$ 2.4$ billion (2002 $\$ 1.5$ billion) and $\$ 0.4$ billion (2002 $\$ 0.7$ billion) being reported against securities trading firms ${ }^{5}$ and foreign banks respectively, instead of against Other Sovereign Issuers; and

- $\$ 0.7$ billion (2002 $\$ 2.7$ billion) and $\$ 1.4$ billion (2002 $\$ 0.1$ billion) being reported against security trading firms and banks respectively, instead of against New Zealand Government.

The Bank's maximum credit risk exposure in relation to derivatives is the cost of re-establishing the derivative contracts in the market in the event of the failure of the counterparty to fulfill its obligations. This cost is the fair value of the derivatives as reported in note 3 .

The Bank's significant end-of-year concentrations of credit exposure based on the entity's country of ownership were as follows.

\begin{tabular}{lrr} 
& 2003 & 2002 \\
& $\$ 000$ & $\$ 000$ \\
\hline New Zealand & $5,482,233$ & $5,850,460$ \\
USA & $3,146,490$ & $2,283,216$ \\
Japan & 892 & 8,569 \\
Europe & $2,811,274$ & $2,850,069$ \\
Supranational Financial Institutions & 182,625 & 262,354 \\
Other & 22,253 & 172,497 \\
Total Financial Assets & $11,645,767$ & $11,427,165$ \\
\cline { 2 - 3 }
\end{tabular}

(c) Credit Exposure by Credit Rating

The following table presents the Bank's financial assets based on Standard and Poor's credit rating of the issuer. AAA is the highest quality rating possible and indicates the entity has an extremely strong capacity to pay interest and principal. AA is a high grade rating, indicating a very strong capacity, and $A$ is an upper medium grade, indicating a strong capacity. BBB is the lowest investment grade rating, indicating a medium capacity to pay interest and principal. Ratings lower than AAA can be modified by + or - signs to indicate relative standing within the major categories. N/R indicates the entity has not been rated by Standard and Poor's. 


\begin{tabular}{|c|c|c|c|c|c|}
\hline & & & $\%$ of 2003 & & $\%$ of 2002 \\
\hline & Credit & 2003 & Financial & 2002 & Financial \\
\hline & Rating & $\$ 000$ & Assets & $\$ 000$ & Assets \\
\hline Foreign Currency Financial Assets & & & & & \\
\hline Cash Balances with Other Central Banks & AAA & 66,577 & $0.6 \%$ & 173,207 & $1.5 \%$ \\
\hline & $A A+$ & - & $0 \%$ & 4,422 & $0 \%$ \\
\hline & AA- & 888 & $0 \%$ & 8,396 & $0.1 \%$ \\
\hline Other Cash Balances & $A A+$ & 642 & $0 \%$ & 3,696 & $0 \%$ \\
\hline & AA- & 1,066 & $0 \%$ & 1,271 & $0 \%$ \\
\hline & $N / R$ & 30 & $0 \%$ & 1,256 & $0 \%$ \\
\hline Marketable Securities & AAA & $2,175,081$ & $18.7 \%$ & $1,821,313$ & $15.9 \%$ \\
\hline & $\mathrm{AA}+$ & 107,614 & $0.9 \%$ & 247,031 & $2.3 \%$ \\
\hline & AA & 212,476 & $1.8 \%$ & 328,581 & $2.9 \%$ \\
\hline & $A A-$ & 781,803 & $6.7 \%$ & 425,434 & $3.7 \%$ \\
\hline Short-Term Advances & AAA & 42,540 & $0.4 \%$ & 184,426 & $1.6 \%$ \\
\hline & AA- & - & $0 \%$ & 163,935 & $1.4 \%$ \\
\hline Receivable from Unsettled Sales of Securities & $\mathrm{AA}+$ & - & $0 \%$ & 24,725 & $0.2 \%$ \\
\hline & $N / R$ & 43,195 & $0.4 \%$ & - & $0 \%$ \\
\hline Securities Purchased Under Agreements to Re-sell & AAA & $2,696,767$ & $23.2 \%$ & $2,194,682$ & $19.3 \%$ \\
\hline & $\mathrm{AA}+$ & 62,244 & $0.5 \%$ & - & $0 \%$ \\
\hline Accrued Interest & Various & 24,728 & $0.2 \%$ & 24,052 & $0.2 \%$ \\
\hline & & $6,215,651$ & $53.4 \%$ & $5,606,427$ & $49.1 \%$ \\
\hline Local Currency Financial Assets & & & & & \\
\hline Cash on Hand & AAA & 4 & $0 \%$ & 4 & $0 \%$ \\
\hline Securities Purchased Under Agreements to Re-sell & AAA & $2,120,364$ & $18.2 \%$ & $2,818,939$ & $24.7 \%$ \\
\hline Investment Portfolio - NZ Government Securities & AAA & $3,242,673$ & $27.8 \%$ & $2,953,554$ & $25.8 \%$ \\
\hline Accrued Interest & AAA & 57,199 & $0.5 \%$ & 48,233 & $0.4 \%$ \\
\hline Other Local Currency Financial Assets & AA- & 9,871 & $0.1 \%$ & - & $0 \%$ \\
\hline & $N / R$ & 5 & $0 \%$ & 8 & $0 \%$ \\
\hline & & $5,430,116$ & $46.6 \%$ & $5,820,738$ & $50.9 \%$ \\
\hline Total Financial Assets & & $11,645,767$ & $100.0 \%$ & $11,427,165$ & $100.0 \%$ \\
\hline Summary by Major Credit Category & & & & & \\
\hline Foreign Currency Financial Assets & AAA & $4,980,965$ & $42.9 \%$ & $4,189,202$ & $36.7 \%$ \\
\hline & $A A+/-$ & $1,166,733$ & $9.9 \%$ & $1,391,917$ & $12.2 \%$ \\
\hline & Various & 24,728 & $0.2 \%$ & 24,052 & $0.2 \%$ \\
\hline & $N / R$ & 43,225 & $0.4 \%$ & 1,256 & $0 \%$ \\
\hline Total Foreign Currency Financial Assets & & $6,215,651$ & $53.4 \%$ & $5,606,427$ & $49.1 \%$ \\
\hline Local Currency Financial Assets & AAA & $5,420,240$ & $46.5 \%$ & $5,820,726$ & $50.9 \%$ \\
\hline & AA- & 9,871 & $0.1 \%$ & 8 & $0 \%$ \\
\hline & $N / R$ & 5 & $0 \%$ & 4 & $0 \%$ \\
\hline Total Local Currency Financial Assets & & $5,430,116$ & $46.6 \%$ & $5,820,738$ & $50.9 \%$ \\
\hline Total Financial Assets & & $11,645,767$ & $100.0 \%$ & $11,427,165$ & $100.0 \%$ \\
\hline
\end{tabular}


(d) Credit Exposure by Counterparty

The table below shows the number of individual counterparties or groups of closely related counterparties where the Bank's credit exposures equalled or exceeded 10 per cent of the Bank's equity ${ }^{6}$ for:

- End-of-year actual credit exposure.

- Peak end-of-day credit exposure (on the basis of limits).

- Peak local currency intra-day credit exposures (on the basis of limits). These exposures arise through intra-day reverse-repurchase agreements entered into with settlement account holders as part of the real time gross settlement system.

\begin{tabular}{|c|c|c|c|c|c|c|}
\hline$\%$ of equity & $\begin{array}{r}\text { End-of-year } \\
2003\end{array}$ & $\begin{array}{r}\text { End-of-year } \\
2002\end{array}$ & $\begin{array}{r}\text { Peak } \\
\text { end-of-day } \\
2003\end{array}$ & $\begin{array}{r}\text { Peak } \\
\text { end-of-day } \\
2002\end{array}$ & $\begin{array}{r}\text { Peak local } \\
\text { currency } \\
\text { intra-day } \\
2003\end{array}$ & $\begin{array}{r}\text { Peak local } \\
\text { currency } \\
\text { intra-day } \\
2002\end{array}$ \\
\hline $10 \%$ to $19.9 \%$ & 8 & 6 & 27 & 22 & 15 & 14 \\
\hline $20 \%$ to $29.9 \%$ & 4 & 3 & 2 & 1 & - & 1 \\
\hline $30 \%$ to $39.9 \%$ & 3 & 1 & - & 1 & 10 & 10 \\
\hline $40 \%$ to $49.9 \%$ & 1 & 1 & 18 & 20 & - & - \\
\hline $50 \%$ to $59.9 \%$ & - & 1 & - & 1 & - & - \\
\hline $60 \%$ to $69.9 \%$ & - & 2 & - & - & - & - \\
\hline $70 \%$ to $79.9 \%$ & 1 & - & - & - & - & - \\
\hline $80 \%$ to $89.9 \%$ & - & - & 18 & 16 & - & - \\
\hline $90 \%$ to $99.9 \%$ & - & - & 4 & 4 & - & - \\
\hline $100 \%$ to $109.9 \%$ & - & - & 3 & 4 & - & - \\
\hline $110 \%$ to $119.9 \%$ & - & - & - & - & - & - \\
\hline $120 \%$ to $129.9 \%$ & - & - & 2 & 1 & - & - \\
\hline $130 \%$ to $139.9 \%$ & - & - & 2 & 2 & - & - \\
\hline $190 \%$ to $199.9 \%$ & - & - & 7 & 6 & - & - \\
\hline $210 \%$ to $219.9 \%$ & - & - & - & - & - & - \\
\hline $240 \%$ to $249.9 \%$ & - & - & 1 & 1 & - & - \\
\hline $280 \%$ to $289.9 \%$ & 1 & - & 1 & - & - & - \\
\hline $330 \%$ to $339.9 \%$ & - & 1 & - & 1 & - & - \\
\hline $470 \%$ to $479.9 \%$ & - & - & - & - & - & - \\
\hline $490 \%$ to $499.9 \%$ & - & - & - & - & - & - \\
\hline $520 \%$ to $529.9 \%$ & - & - & - & - & - & - \\
\hline $540 \%$ to $549.9 \%$ & - & 1 & - & 1 & - & - \\
\hline $720 \%$ to $729.9 \%$ & 1 & - & 1 & - & - & - \\
\hline
\end{tabular}

Peak end-of-day exposures greater than 100 per cent of the Bank's equity were to sovereign issuers and supranational financial institutions. The Bank does not constrain credit exposure to certain sovereign issuers (e.g. the United States of America). Exposures to these sovereign issuers are managed through other limits and controls (such as currency composition limits). End-of-year exposures greater than 100 per cent were to highly-rated sovereign issuers. Peak end-of-day exposures to these sovereign issuers are based on end-of-year exposures. 


\section{Interest Rate Risk}

Interest rate risk is the risk of loss arising from changes in interest rates.

\section{Foreign Currency Interest Rate Risk}

The Reserve Bank's "neutral” asset portfolios involve some interest rate risk because the Bank's foreign currency assets are funded by foreign currency liabilities whose interest rate characteristics cannot be exactly replicated. The interest rate characteristics of the liabilities are similar to those of highly-rated bank and corporate instruments, but liquidity considerations require that a significant proportion of investments are in United States and German domestic government instruments, which have different interest rate characteristics to the liabilities. The Bank accepts the associated interest rate risk as inevitable, but seeks to closely limit additional, mainly duration-related, interest rate mismatches. The Bank is continually reviewing investment opportunities for ways to reduce the costs and risks associated with holding reserves, while maintaining the liquidity of its intervention assets.

Interest rate risk arising from departures from the neutral position is managed by way of Value at Risk limits and stop-loss limits for the Bank's combined market risk as described in note 21.

\section{Local Currency Interest Rate Risk}

Interest rate risk on the Investment Portfolio - New Zealand Government Securities is not actively managed as a matter of policy. This recognises that:

- active risk management could require the Bank to carry out transactions that conflict with the Bank's monetary policy stance; and

- the investment portfolio held by the Bank is exactly matched by liabilities held by the Crown, so from a consolidated Crown position the interest rate risk is eliminated.

The duration of the investment portfolio at 30 June 2003 was 5.7 years (2002 5.6 years).

The Bank's exposure to interest rate risk that arises from liquidity management operations is minimal, due to the very short-term nature of the exposures created and because the exposures are offset by other interest-bearing assets and liabilities. 
Assets and liabilities will mature or re-price within the following periods.

\begin{tabular}{|c|c|c|c|c|c|c|c|c|}
\hline \multirow[b]{4}{*}{ Acat 30 lune 2003} & Weighted & \multicolumn{3}{|c|}{ Non- } & \multirow[b]{2}{*}{6 to 12} & \multirow[b]{2}{*}{1 to 2} & \multirow[b]{2}{*}{2 to 5} & \multirow[b]{2}{*}{ Over 5} \\
\hline & Average & Total & Interest & 6 Months & & & & \\
\hline & Interest & 2003 & Sensitive & or Less & Months & Years & Years & Years \\
\hline & Rate & $\$ 000$ & $\$ 000$ & $\$ 000$ & $\$ 000$ & $\$ 000$ & $\$ 000$ & $\$ 000$ \\
\hline \multicolumn{9}{|l|}{ Foreign Currency Financial Assets } \\
\hline Cash Balances with Other Central Banks & $1.13 \%$ & 67,465 & - & 67,465 & - & - & - & - \\
\hline Other Cash Balances & $1.12 \%$ & 1,738 & - & 1,738 & - & - & - & - \\
\hline Marketable Securities & $1.62 \%$ & $3,276,974$ & - & $2,578,027$ & 149,250 & 149,712 & 286,970 & 113,015 \\
\hline Short-Term Advances & $1.08 \%$ & 42,540 & - & 42,540 & - & - & - & - \\
\hline Receivable from Unsettled Sales of Securities & $0 \%$ & 43,195 & - & 43,195 & - & - & - & - \\
\hline Securities Purchased Under Agreements to Re-sell & $1.22 \%$ & $2,759,011$ & - & $2,759,011$ & - & - & - & - \\
\hline Accrued Interest & $0 \%$ & 24,728 & - & 24,728 & - & - & - & - \\
\hline Total Foreign Currency Financial Assets & $1.42 \%$ & $6,215,651$ & - & $5,516,704$ & 149,250 & 149,712 & 286,970 & 113,015 \\
\hline \multicolumn{9}{|l|}{ Foreign Currency Financial Liabilities } \\
\hline Short-Term Deposits & $0.30 \%$ & 1,335 & - & 1,335 & - & - & - & - \\
\hline Payable for Unsettled Purchases of Securities & $0 \%$ & 42,610 & - & 42,610 & - & - & - & - \\
\hline Short Sales of Marketable Securities & $2.93 \%$ & 93,706 & - & - & - & 20,266 & 62,470 & 10,970 \\
\hline Derivative Instruments in a Loss Position & $2.77 \%$ & 3,078 & - & 3,078 & - & - & - & - \\
\hline Securities Sold Under Agreements to Repurchase & $0.89 \%$ & 840,663 & - & 840,663 & - & - & - & - \\
\hline Term Liabilities & $1.80 \%$ & $4,068,882$ & - & $2,877,554$ & 110,198 & - & $1,081,130$ & - \\
\hline Accrued Interest & $0 \%$ & 51,455 & - & 51,455 & - & - & - & - \\
\hline Total Foreign Currency Financial Liabilities & $1.64 \%$ & $5,101,729$ & - & $3,816,695$ & 110,198 & 20,266 & $1,143,600$ & 10,970 \\
\hline Foreign Currency Interest Rate Sensitivity Gap ${ }^{7}$ & & $1,113,922$ & - & $1,700,009$ & 39,052 & 129,446 & $(856,630)$ & 102,045 \\
\hline \multicolumn{9}{|l|}{ Local Currency Financial Assets } \\
\hline Cash on Hand & $0 \%$ & 4 & - & 4 & - & - & - & - \\
\hline Securities Purchased Under Agreements to Re-sell & $5.18 \%$ & $2,120,364$ & - & $2,120,364$ & - & - & - & - \\
\hline Investment Portfolio - NZ Government Securities & $6.70 \%$ & $3,242,673$ & - & - & 148,997 & 580,118 & 880,821 & $1,632,737$ \\
\hline Accrued Interest & $0 \%$ & 57,199 & - & 57,199 & - & - & - & - \\
\hline Other Local Currency Financial Assets & $5.22 \%$ & 9,876 & - & 9,876 & - & - & - & - \\
\hline Other Assets & $0 \%$ & 38,307 & 38,307 & - & - & - & - & - \\
\hline Total Local Currency Assets & $5.99 \%$ & $5,468,423$ & 38,307 & $2,187,443$ & 148,997 & 580,118 & 880,821 & $1,632,737$ \\
\hline \multicolumn{9}{|l|}{ Local Currency Financial Liabilities } \\
\hline Government Deposits & $5.25 \%$ & $3,142,296$ & - & $3,142,296$ & - & - & - & - \\
\hline Other Deposits & $0.45 \%$ & 22,730 & - & 22,730 & - & - & - & - \\
\hline Accrued Interest & $0 \%$ & 468 & - & 468 & - & - & - & - \\
\hline Other Liabilities & $0 \%$ & $3,000,698$ & $3,000,698$ & - & - & - & - & - \\
\hline Equity & $0 \%$ & 416,153 & 416,153 & - & - & - & - & - \\
\hline Total Local Currency Liabilities and Equity & $2.51 \%$ & $6,582,345$ & $3,416,851$ & $3,165,494$ & - & - & - & - \\
\hline Local Currency Interest Rate Sensitivity Gap ${ }^{7}$ & & $(1,113,922)$ & $(3,378,544)$ & $(978,051)$ & 148,997 & 580,118 & 880,821 & $1,632,737$ \\
\hline On-Balance Sheet Interest Rate Sensitivity Gap & & - & $(3,378,544)$ & 721,958 & 188,049 & 709,564 & 24,191 & $1,734,782$ \\
\hline Off-Balance Sheet Instruments & & - & - & $(545,030)$ & $(80,074)$ & $(1,191)$ & 654,891 & $(28,596)$ \\
\hline Total Interest Rate Sensitivity Gap & & - & $(3,378,544)$ & 176,928 & 107,975 & 708,373 & 679,082 & $1,706,186$ \\
\hline \multicolumn{9}{|l|}{ All Currencies } \\
\hline New Zealand & & $(15,000)$ & $(3,378,544)$ & 120,871 & 148,997 & 580,118 & 880,821 & $1,632,737$ \\
\hline United States & & 8,314 & - & 121,113 & $(1,301)$ & 16,550 & $(112,242)$ & $(15,806)$ \\
\hline Euro & & (135) & - & $(73,285)$ & $(39,721)$ & 111,705 & $(89,497)$ & 90,663 \\
\hline Japan & & 1,106 & - & 1,106 & - & - & - & - \\
\hline Other & & 5,715 & - & 7,123 & - & - & - & $(1,408)$ \\
\hline
\end{tabular}


Comparative figures as at 30 June 2002 were as follows.

\begin{tabular}{|c|c|c|c|c|c|c|c|c|}
\hline & Weighted & & Non- & & & & & \\
\hline & Average & Total & Interest & 6 Months & 6 to 12 & 1 to 2 & 2 to 5 & Over 5 \\
\hline & Interest & 2002 & Sensitive & Or Less & Months & Years & Years & Years \\
\hline As at 30 June 2002 & Rate & $\$ 000$ & $\$ 000$ & $\$ 000$ & $\$ 000$ & $\$ 000$ & $\$ 000$ & $\$ 000$ \\
\hline
\end{tabular}

\section{Foreign Currency Financial Assets}

Cash Balances with Other Central Banks

Other Cash Balances

Marketable Securities

Short-Term Advances

Receivable from Unsettled Sales of Securities

Securities Purchased Under Agreements to Re-sell

Accrued Interest

Total Foreign Currency Financial Assets

Foreign Currency Financial Liabilities

Payable for Unsettled Purchases of Securities

Short Sales of Marketable Securities

Derivative Instruments in a Loss Position

Securities Sold Under Agreements to Repurchase

Term Liabilities

Accrued Interest

Total Foreign Currency Financial Liabilities

Foreign Currency Interest Rate Sensitivity Gap

Local Currency Financial Assets

Cash on Hand

Securities Purchased Under Agreements to Re-sell

Investment Portfolio - NZ Government Securities

Accrued Interest

Other Local Currency Financial Assets

Other Assets

Total Local Currency Assets

Local Currency Financial Liabilities

Government Deposits

Other Deposits

Accrued Interest

Other Liabilities

Equity

Total Local Currency Liabilities and Equity

Local Currency Interest Rate Sensitivity Gap

On-Balance Sheet Interest Rate Sensitivity Gap

Off-Balance Sheet Instruments

Total Interest Rate Sensitivity Gap

All Currencies

New Zealand

United States

Euro

Japan

Other

\begin{tabular}{rrrrrrrr}
$2.79 \%$ & 186,025 & - & 186,025 & - & - & - & - \\
$2.25 \%$ & 6,223 & - & 6,223 & - & - & - & - \\
$2.43 \%$ & $2,822,359$ & - & $2,124,257$ & 6,839 & 336,552 & 273,725 & 80,986 \\
$1.77 \%$ & 348,361 & - & 348,361 & - & - & - & - \\
$0 \%$ & 24,725 & - & 24,725 & - & - & - & - \\
$2.37 \%$ & $2,194,682$ & - & $2,194,682$ & - & - & - & - \\
$0 \%$ & 24,052 & - & 24,052 & - & - & - & - \\
\hline $2.36 \%$ & $5,606,427$ & - & $4,908,325$ & 6,839 & 336,552 & 273,725 & 80,986 \\
& & & & & & & \\
$0 \%$ & 55,254 & - & 55,254 & - & - & - & - \\
$3.91 \%$ & 61,344 & - & - & - & - & 61,344 & - \\
$0 \%$ & 14,533 & - & 14,533 & - & - & - & - \\
$2.05 \%$ & 991,740 & - & 991,740 & - & - & - & - \\
$2.56 \%$ & $4,063,936$ & - & $2,554,913$ & - & 337,956 & $1,171,067$ & - \\
$0 \%$ & 66,334 & - & 66,334 & - & - & - & - \\
\hline $2.41 \%$ & $5,253,141$ & - & $3,682,774$ & - & 337,956 & $1,232,411$ & - \\
\hline & 353,286 & - & $1,225,551$ & 6,839 & $(1,404)$ & $(958,686)$ & 80,986
\end{tabular}

\begin{tabular}{rrrrrrrr}
$0 \%$ & 4 & - & 4 & - & - & - & - \\
$5.58 \%$ & $2,818,939$ & - & $2,818,939$ & - & - & - & - \\
$6.93 \%$ & $2,953,554$ & - & - & 445,865 & 149,564 & $1,029,109$ & $1,329,016$ \\
$0 \%$ & 48,233 & - & 48,233 & - & - & - & - \\
$6.89 \%$ & 8 & - & 4 & 3 & 1 & - & - \\
$0 \%$ & 38,090 & 38,090 & - & - & - & - & - \\
\hline $6.18 \%$ & $5,858,828$ & 38,090 & $2,867,180$ & 445,868 & 149,565 & $1,029,109$ & $1,329,016$
\end{tabular}

\begin{tabular}{rrrrrrrr}
$5.50 \%$ & $2,945,860$ & - & $2,945,860$ & - & - & - & - \\
$5.25 \%$ & 14,673 & - & 14,673 & - & - & - & - \\
$0 \%$ & 1,346 & - & 1,346 & - & - & - & - \\
$0 \%$ & $2,838,763$ & $2,838,763$ & - & - & - & - & - \\
$0 \%$ & 411,472 & 411,472 & - & - & - & - & - \\
\hline $2.62 \%$ & $6,212,114$ & $3,250,235$ & $2,961,879$ & - & - & - & - \\
\hline & $(353,286)$ & $(3,212,145)$ & $(94,699)$ & 445,868 & 149,565 & $1,029,109$ & $1,329,016$ \\
\hline & - & $(3,212,145)$ & $1,130,852$ & 452,707 & 148,161 & 70,423 & $1,410,002$ \\
& - & - & $(794,662)$ & $(32,787)$ & $(35,988)$ & 812,059 & 51,378 \\
\hline & - & $(3,212,145)$ & 336,190 & 419,920 & 112,173 & 882,482 & $1,461,380$
\end{tabular}

\begin{tabular}{rrrrrrr}
\hline \hline$(1,233)$ & $(3,212,145)$ & 257,354 & 445,868 & 149,565 & $1,029,109$ & $1,329,016$ \\
$(1,894)$ & - & 39,196 & $(32,303)$ & 65,967 & $(74,754)$ & - \\
$(2,236)$ & - & 58,233 & 6,355 & $(103,359)$ & $(71,873)$ & 108,408 \\
1,512 & - & $(22,444)$ & - & - & - & 23,956 \\
3,851 & - & 3,851 & - & - & - & -
\end{tabular}




\section{Foreign Currency Risk}

Foreign currency risk is the risk of loss arising from changes in exchange rates. The assets held in foreign currency portfolios are largely matched by foreign currency liabilities of approximately equal value. The Reserve Bank's exposure to foreign currency risk arises from trading positions undertaken by specialist staff. Foreign currency risk is managed by way of Value at Risk limits and stop-loss limits for the Bank's combined market risk as described in note 21.

Foreign currency assets and liabilities arising from domestic Market Operations are fully hedged using forward foreign currency swaps.

As at 30 June, the Bank's net exposure to major currencies, including forward foreign exchange swap contracts and foreign currency swaps, was as follows.

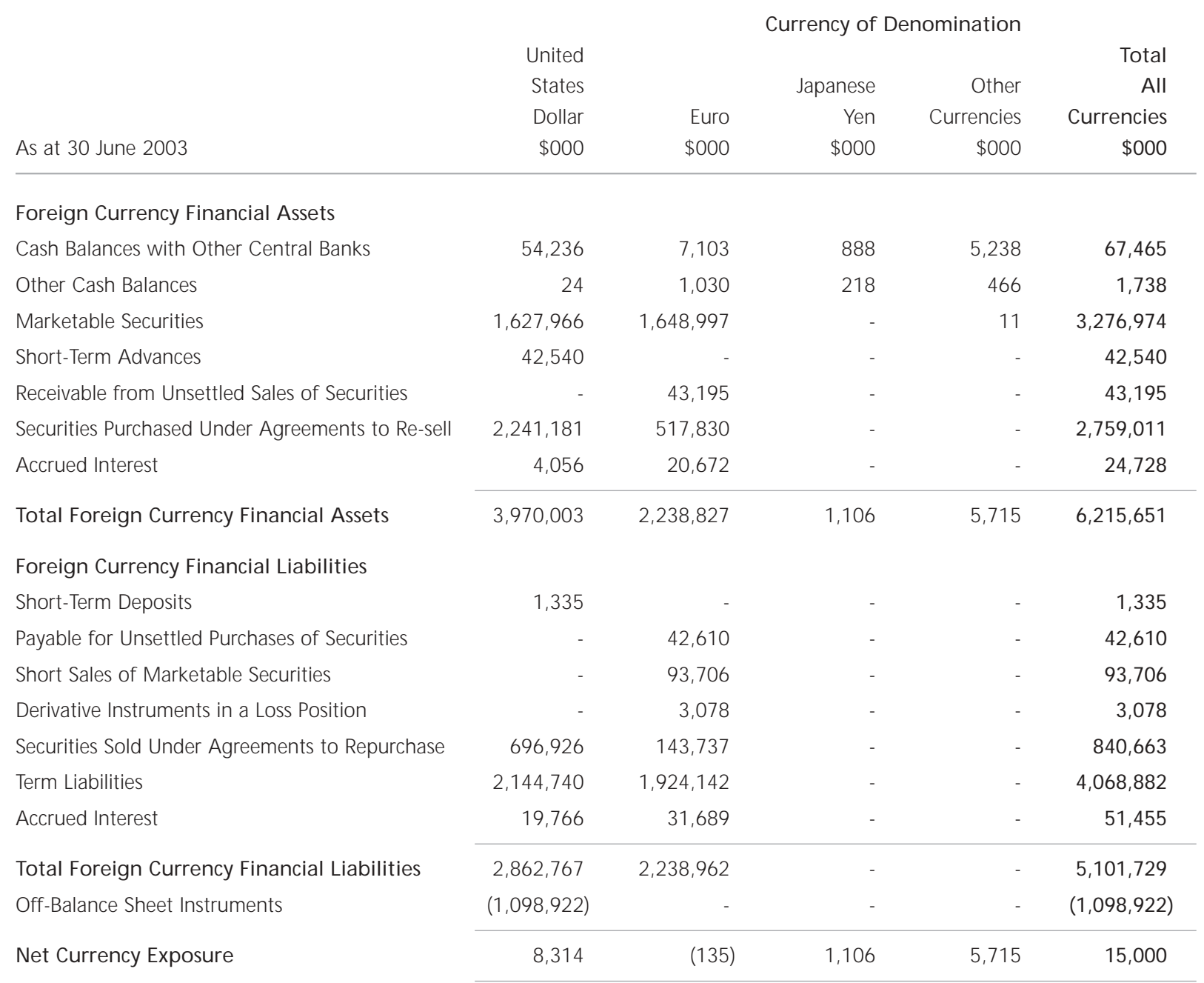

All net currency exposures were within approved limits at balance date. 


\begin{tabular}{|c|c|c|c|c|c|}
\hline & & & urrency of & lomination & \\
\hline & United & & & & Total \\
\hline & States & & Japanese & Other & All \\
\hline & Dollar & Euro & Yen & Currencies & Currencies \\
\hline As at 30 June 2002 & $\$ 000$ & $\$ 000$ & $\$ 000$ & $\$ 000$ & $\$ 000$ \\
\hline Foreign Currency Financial Assets & & & & & \\
\hline Cash Balances with Other Central Banks & 44,064 & 127,731 & 8,396 & 5,834 & 186,025 \\
\hline Other Cash Balances & 992 & 2,394 & 1,462 & 1,375 & 6,223 \\
\hline Marketable Securities & $1,848,035$ & 957,229 & 17,095 & - & $2,822,359$ \\
\hline Short-Term Advances & 348,361 & - & - & - & 348,361 \\
\hline Receivable from Unsettled Sales of Securities & - & 24,725 & - & - & 24,725 \\
\hline Securities Purchased Under Agreements to Re-sell & $1,412,225$ & 782,457 & - & - & $2,194,682$ \\
\hline Accrued Interest & 6,648 & 17,404 & - & - & 24,052 \\
\hline Total Foreign Currency Financial Assets & $3,660,325$ & $1,911,940$ & 26,953 & 7,209 & $5,606,427$ \\
\hline Foreign Currency Financial Liabilities & & & & & \\
\hline Payable for Unsettled Purchases of Securities & - & 55,254 & - & - & 55,254 \\
\hline Short Sales of M arketable Securities & - & 61,344 & - & - & 61,344 \\
\hline Derivative Instruments in a Loss Position & - & 14,021 & 296 & 216 & 14,533 \\
\hline Securities Sold Under Agreements to Repurchase & 902,709 & 89,031 & - & - & 991,740 \\
\hline Term Liabilities & $2,339,056$ & $1,562,937$ & 161,943 & - & $4,063,936$ \\
\hline Accrued Interest & 26,872 & 30,026 & 9,436 & - & 66,334 \\
\hline Total Foreign Currency Financial Liabilities & $3,268,637$ & $1,812,613$ & 171,675 & 216 & $5,253,141$ \\
\hline Off-Balance Sheet Instruments & $(393,582)$ & $(101,563)$ & 146,234 & $(3,142)$ & $(352,053)$ \\
\hline Net Currency Exposure & $(1,894)$ & $(2,236)$ & 1,512 & 3,851 & 1,233 \\
\hline
\end{tabular}

\section{Market Risk}

The Reserve Bank manages interest rate risk and foreign currency risk in an integrated manner under the following market risk management arrangements.

(a) Tolerance for Extreme Market Risk Losses

The Governor's tolerance for loss from interest rate risk and foreign currency risk is no more than \$75 million (2002 \$100 million) in aggregate in any financial year. Within this aggregate outer tolerance for market risk losses, the Governor's tolerance for market risk losses from actively managed positions is $\$ 25$ million (2002 $\$ 50$ million) in any financial year. Stress testing (outlined below) is used to verify the robustness of the loss tolerances in times of extreme global financial market crises.

(b) VaR Limits and Stress Testing

Interest rate and foreign exchange risks are controlled on a day-to-day basis by way of Value at Risk (VaR) limits. VaR estimates the potential daily loss from movements in market risks (interest rates and foreign currencies movements) in normal market conditions. The Bank uses a parametric VaR model based on equally weighted data for the previous year (260 trading days), a one day time horizon and a $99 \%$ confidence interval. This means the Bank would expect to incur losses greater than predicted by VaR estimates only once every 100 trading days, or about 2.5 times a year. VaR does not capture market risk losses arising from the extreme price volatility associated with financial market crises so VaR limits are set well inside outer tolerances for market risk losses to allow for losses arising from extreme financial crises. The Bank calibrates the allowance for extreme market risk losses by modelling the impact of previous global financial crises on a representative diversified portfolio that fully utilises VaR limits.

VaR limits are set for the aggregate portfolios (total foreign reserves assets and liabilities), risk-neutral portfolios, and actively managed portfolios (trading portfolios). The VaR for the trading portfolios is calculated as the difference between the actual portfolios and neutral portfolios. 


\begin{tabular}{lrrrrrr} 
& $\begin{array}{r}\text { Actual } \\
\text { Portfolios }\end{array}$ & & $\begin{array}{r}\text { Neutral } \\
\text { Portfolios }\end{array}$ & \multicolumn{3}{c}{$\begin{array}{r}\text { Trading } \\
\text { Portfolios }\end{array}$} \\
VaR & 2003 & 2002 & 2003 & 2002 & 2003 & 2002 \\
\hline \multirow{2}{*}{ Limit } & $\$ 000$ & $\$ 000$ & $\$ 000$ & $\$ 000$ & $\$ 000$ & $\$ 000$ \\
As at 30 June & 6,000 & 10,000 & 4,000 & 4,000 & 2,000 & 6,000 \\
Peak over period & 321 & 390 & 238 & 342 & 83 & 48 \\
Low over period & 1,045 & 2,063 & 482 & 2,069 & 615 & 1,303 \\
Average over period & 177 & 373 & 159 & 343 & $(48)$ & $(103)$ \\
& 379 & 1,228 & 274 & 1,153 & 105 & 75
\end{tabular}

In the year to 30 June 2003, actual daily losses on the traded portfolios were within (predicted) VaR 99 per cent (2002 97 per cent) of the time. Losses which exceed VaR more frequently than expected are analysed to verify the integrity of the VaR model and the results of analysis are reported to senior management at Risk Management Committee.

The composition of market risk for the aggregate portfolios is as follows.

\begin{tabular}{|c|c|c|c|c|c|}
\hline & Foreign & Interest & & $\begin{array}{r}\text { Total } \\
\text { Market Risk }\end{array}$ & $\begin{array}{r}\text { Total } \\
\text { M arket Risk }\end{array}$ \\
\hline & Currency Risk & Rate Risk & Correlation $^{8}$ & 2003 & 2002 \\
\hline VaR & $\$ 000$ & $\$ 000$ & $\$ 000$ & $\$ 000$ & $\$ 000$ \\
\hline Limit & & & & 6,000 & 10,000 \\
\hline As at 30 June & 73 & 431 & (183) & 321 & 390 \\
\hline Peak over period & 109 & 1,286 & $(350)$ & 1,045 & 2,063 \\
\hline Low over period & 72 & 225 & $(120)$ & 177 & 373 \\
\hline Average over period & 113 & 519 & (253) & 379 & 1,228 \\
\hline
\end{tabular}

\section{(c) Stop-Loss Limits}

Stop-loss limits are set to control losses that may arise from departures from the risk neutral position. A stop-loss limit of $\$ 6$ million in any rolling 20-day trading period and $\$ 9$ million in any rolling 250 day trading period is applied to the aggregate interest rate and foreign currency losses from trading positions. When aggregate market risk losses exceed the stop-loss limit, positions are closed down. The Governor must approve the re-establishment of positions. 


\section{Liquidity Risk}

Liquidity risk is the risk that an entity will encounter difficulty in raising funds at short notice to meet commitments associated with financial instruments. Liquidity risk is also the risk that an entity will have to sell a financial asset quickly at much less than its fair value.

\section{Foreign Currency Activities}

Liquidity is a key criterion in determining the composition of the Reserve Bank's foreign currency assets. This reflects the potential requirement to liquefy foreign reserves for intervention purposes, should the need arise. Accordingly, there is an array of interacting controls aimed at ensuring quick access to funds. These controls include liquid asset ratios based on the liquidity characteristics of securities held and limits on the minimum and maximum proportion of reserves that may be held in any one currency. These limits are monitored daily.

The Bank has additional liquidity arrangements for foreign currency assets including:

- Repurchase agreements with other central banks enabling the Bank to sell securities in exchange for foreign currency, while simultaneously agreeing to repurchase those same securities at a specified later date for an agreed amount. In essence, the arrangement allows the Bank to enhance the liquidity of its foreign reserves portfolio with minimum additional risks.

- A committed credit line (US $\$ 100$ million) to augment the foreign currency that can be accessed quickly.

\section{Local Currency Activities}

The Bank is responsible for managing the daily liquidity of the banking system. This includes advancing funds to and withdrawing funds from the banking system to smooth out daily liquidity peaks and troughs. The nature of these activities, which mostly involve offsetting the flow of funds from the Crown to settlement banks, is such that the Bank is not subject to the liquidity constraints that impact on other organisations. 


\section{Maturity Analysis}

As at 30 June 2003

Foreign Currency Financial Assets

Cash Balances with Other Central Banks

Other Cash Balances

M arketable Securities

Short-Term Advances

Receivable from Unsettled Sales of Securities

Securities Purchased Under Agreements to Re-sell

Accrued Interest

Total Foreign Currency Financial Assets

Foreign Currency Financial Liabilities

Short-Term Deposits

Payable for Unsettled Purchases of Securities

Short Sales of Marketable Securities

Derivative Instruments in a Loss Position

Securities Sold Under Agreements to Repurchase

Term Liabilities

Accrued Interest

Total Foreign Currency Financial Liabilities

Foreign Currency Maturity Gap

$67,465 \quad 67,465$

$1,738 \quad 1,738$

$3,276,974 \quad 2,578,028$

$42,540 \quad 42,540$

$43,195 \quad 43,195$

$2,759,011 \quad 2,759,011$

$24,728 \quad 24,728$

$6,215,651 \quad 5,516,705$

149,249

149,712

286,969

113,016

Local Currency Financial Assets

Cash on Hand

Securities Purchased Under Agreements to Re-sell Investment Portfolio - NZ Government Securities Accrued Interest

Other Local Currency Financial Assets

Other Assets

Total Local Currency Assets

Local Currency Financial Liabilities

Government Deposits

Other Deposits

Accrued Interest

Other Liabilities

Equity

Total Local Currency Liabilities and Equity

Local Currency Maturity Gap

Net Maturity Gap
(1)

\begin{tabular}{rrrrrr}
1,335 & 1,335 & - & - & - & - \\
42,610 & 42,610 & - & - & - & - \\
93,706 & - & - & 20,266 & 62,470 & 10,970 \\
3,078 & 1,155 & 1,627 & - & - & 296 \\
840,663 & 840,663 & - & - & - & - \\
$4,068,882$ & 468,199 & 178,241 & 635,867 & $2,105,156$ & 681,419 \\
51,455 & 51,455 & - & - & - & - \\
\hline $5,101,729$ & $1,405,417$ & 179,868 & 656,133 & $2,167,626$ & 692,685 \\
\hline $1,113,922$ & $4,111,288$ & $(30,619)$ & $(506,421)$ & $(1,880,657)$ & $(579,669)$
\end{tabular}

$\begin{array}{rrrrrr}4 & 4 & - & - & - & - \\ 2,120,364 & 2,120,364 & - & - & - & - \\ 3,242,673 & - & 148,997 & 580,118 & 880,821 & 1,632,737 \\ 57,199 & 57,199 & - & - & - & - \\ 9,876 & 9,876 & - & - & - & - \\ 38,307 & 9,612 & - & - & 4,511 & 24,184 \\ 5,468,423 & 2,197,055 & 148,997 & 580,118 & 885,332 & 1,656,921\end{array}$

\begin{tabular}{rrrrrr}
$3,142,296$ & $3,142,296$ & - & - & - & - \\
22,730 & 22,730 & - & - & - & - \\
468 & 468 & - & - & - & - \\
$3,000,698$ & 190,436 & 133 & - & 1,079 & $2,809,050$ \\
416,153 & - & - & - & - & 416,153 \\
\hline $6,582,345$ & $3,355,930$ & 133 & - & 1,079 & $3,225,203$ \\
\hline$(1,113,922)$ & $(1,158,875)$ & 148,864 & 580,118 & 884,253 & $(1,568,282)$ \\
\hline- & $2,952,413$ & 118,245 & 73,697 & $(996,404)$ & $(2,147,951)$ \\
\hline
\end{tabular}


Foreign Currency Financial Assets

Cash Balances with Other Central Banks

Other Cash Balances

M arketable Securities

Short-Term Advances

Receivable from Unsettled Sales of Securities

Securities Purchased Under Agreements to Re-sell

Accrued Interest

Total Foreign Currency Financial Assets

Foreign Currency Financial Liabilities

Short-Term Deposits

Payable for Unsettled Purchases of Securities

Short Sales of M arketable Securities

Derivative Instruments in a Loss Position

Securities Sold Under Agreements to Repurchase

Term Liabilities

Accrued Interest

Total Foreign Currency Financial Liabilities

Foreign Currency Maturity Gap

Local Currency Financial Assets

Cash on Hand

Securities Purchased Under Agreements to Re-sell Investment Portfolio - NZ Government Securities Accrued Interest

Other Local Currency Financial Assets

Other Assets

Total Local Currency Assets

Local Currency Financial Liabilities

Government Deposits

Other Deposits

Accrued Interest

Other Liabilities

Equity

Total Local Currency Liabilities and Equity

Local Currency Maturity Gap

Net Maturity Gap

$\begin{array}{rrrrrr}186,025 & 186,025 & - & - & - & - \\ 6,223 & 6,223 & - & - & - & - \\ 2,822,359 & 2,107,344 & 6,839 & 336,552 & 290,638 & 80,986 \\ 348,361 & 348,361 & - & - & - & - \\ 24,725 & 24,725 & - & - & - & - \\ 2,194,682 & 2,194,682 & - & - & - & - \\ 24,052 & 24,052 & - & - & - & - \\ 5,606,427 & 4,891,412 & 6,839 & 336,552 & 290,638 & 80,986\end{array}$

$55,254 \quad 55,254$

61,344

$14,533 \quad 12,792$

$991,740 \quad 991,740$

4,063,936 161,943

$66,334 \quad 66,334$

$5,253,141 \quad 1,288,063$

$\begin{array}{llllll}353,286 & 3,603,349 & (246,534) & (392,433) & (2,140,653) & (470,443)\end{array}$

4

$2,818,939 \quad 2,818,939$

$2,953,554$

48,233

8

38,090

$5,858,828 \quad 2,875,302$

233

4

8,122

$, 875,302$

$2,945,860 \quad 2,945,860$

$14,673 \quad 14,673$

$1,346 \quad 1,346$

$2,838,763 \quad 176,722$

411,472

-

$6,212,114 \quad 3,138,601$

$(353,286)$
445,868

$\begin{array}{lll}- & 5,357 \quad 24,611\end{array}$

$\begin{array}{llll}445,865 & 149,564 & 1,029,109 & 1,329,016\end{array}$

$1,034,466 \quad 1,353,627$

$605 \quad 2,661,436$

- 411,472

$6053,072,908$ 


\section{Consolidated Statement of Cost of Services Notes}

\section{Currency Operations}

Seigniorage is the income directly associated with the issue of currency and provides the Reserve Bank with its main source of income. Registered banks pay the Bank the face value of the currency issued to them. These funds are invested in New Zealand government securities, which are included in local currency financial assets, to back the currency in circulation liability. Currency in circulation is a noninterest bearing liability. However, the New Zealand government securities investment portfolio is interest bearing. The resulting interest income is seigniorage.

As part of the Currency Operations function, the Bank issues collectors' currency. The net profit for this activity in 2003 was $\$ 86,000$ (2002 $\$ 229,000$ profit) this included a currency stock write-off of $\$ 183,000$.

\begin{tabular}{lrr} 
& 2003 & 2002 \\
& $\$ 000$ & $\$ 000$ \\
\hline Seigniorage & 190,754 & 183,220 \\
Other Income & 6 & 2,677 \\
Operating Income & 190,760 & 185,897 \\
New Note Issue Expenses & 2,198 & 1,119 \\
New Coin Issue Expenses & 3,651 & 3,064 \\
Collectors' Currency Issue Expenses & 192 & 537 \\
Currency Issue Expenses & 6,041 & 4,720 \\
Other Currency Expenses & 3,337 & 5,327 \\
Operating Expenses & 9,378 & 10,047 \\
Currency Operations Operating Surplus & 181,382 & 175,850 \\
\hline
\end{tabular}

\section{Foreign Reserves Management}

The Reserve Bank holds foreign currency assets to enable intervention in the foreign exchange market, should that ever prove necessary. These foreign reserves are fully funded by foreign currency borrowings through the Treasury. New Zealand pays more to borrow overseas than it can earn investing in high quality assets able to be realised quickly. As a result, holding reserves involves a small net cost, although some reduction in that cost is possible through active management of the holdings.

Subject to liquidity and credit risk constraints being satisfied, the Bank defines benchmark portfolios that represent a "neutral" asset and liability structure in terms of market risk. The neutral position is established to minimise the Bank's exposure to foreign currency risk and interest rate risk. Departures from the neutral position involve discretionary trading and portfolio management decisions, and quantitative trading strategies, undertaken by specialist staff with delegated authority from the Governor. The net gain or loss arising from departures from the neutral portfolio represents the active management of reserves. 
Active Management Trading Gain (Loss)

Gain (Loss) on Neutral Asset/Liability Structure

$(4,843) \quad(11,674)$

Net Investment Income

$(5,231)$

$(9,792)$

Other

Foreign Exchange Difference on Translation

Foreign Reserves Management Gain (Loss)

$(5,560)$

Residual Income Allocation ${ }^{10}$

16,754

13,321

Operating Income

11,194

3,134

Operating Expenses

3,878

3,915

Foreign Reserves Management Operating Surplus

7,316

For further information on the Foreign Reserves Management Function, see note 1, parts (a) to (f). Further information on risk management is contained in notes 16 to 22.

\section{Overseas Investment Commission Secretariat}

The Overseas Investment Commission (Commission) administers New Zealand's legislative controls on major inward foreign direct investment. The Reserve Bank provides the secretariat of the Commission and funds its activities to the extent these are not covered by application fees.

The cost of services of the Overseas Investment Commission Secretariat (the "OIC") for the year ended 30 June 2003 was as follows.

\begin{tabular}{lrr} 
& 2003 & 2002 \\
& $\$ 000$ & $\$ 000$ \\
\hline Application Fees & 816 & 848 \\
Other & 5 & 7 \\
Operating Income & 821 & 855 \\
Personnel & 350 & 363 \\
Administration & 29 & 30 \\
Asset Management & 48 & 66 \\
Professional Services & 142 & 64 \\
Legal Fees & 11 & 287 \\
Computing Expenses & 73 & 72 \\
Other & 15 & 56 \\
Operating Expenses & 668 & 938 \\
Overseas Investment Commission Secretariat Operating Surplus (Deficit) & 153 & $(83)$
\end{tabular}

The 2002 legal fees arose from a judicial review of an Overseas Investment Commission ruling. 
Fees for the OIC were introduced on 15 January 1996. Under the Funding Agreement from 1 July 2000, the OIC operating surplus (deficit) is retained by the Bank. The annual operating income and surplus (deficit) since 15 January 1996 was as follows.

\begin{tabular}{|c|c|c|}
\hline & $\begin{array}{r}\text { Operating } \\
\text { Income } \\
\$ 000\end{array}$ & $\begin{array}{r}\text { Operating } \\
\text { Surplus (Deficit) } \\
\$ 000\end{array}$ \\
\hline 1996 (six months) & 373 & 46 \\
\hline 1997 & 589 & (116) \\
\hline 1998 & 583 & (279) \\
\hline 1999 & 764 & 41 \\
\hline 2000 & 628 & (63) \\
\hline 2001 & 581 & (94) \\
\hline 2002 & 855 & (83) \\
\hline \multirow[t]{2}{*}{2003} & 821 & 153 \\
\hline & 5,194 & (395) \\
\hline
\end{tabular}

\section{Registry and Depository Services}

The Reserve Bank provides registrar and paying agency services to issuers of fixed interest securities. The Bank also operates the Austraclear New Zealand System, which provides the financial markets with depository, clearing, and settlement services for debt securities and equities. Though the Bank outsourced the processing of registry services to Computershare Investor Services (NZ) Limited, the Bank remains responsible for the services now carried out on its behalf.

\begin{tabular}{lrr} 
& 2003 & 2002 \\
& $\$ 000$ \\
\hline Fees for Registry and Depository Services & 5,081 & 5,162 \\
Other Income & 288 & 653 \\
Operating Income & 5,369 & 5,815 \\
Personnel & 714 & 830 \\
Other & 3,234 & 3,104 \\
Operating Expenses & 3,948 & 3,934 \\
Registry and Depository Services Operating Surplus & 1,421 & 1,881
\end{tabular}




\section{Consolidated Statement of Financial Performance Notes}

\section{Interest Income from Financial Assets}

Interest Income from Foreign Currency Financial Assets

Cash Balances with Other Central Banks

$4,038 \quad 4,189$

Other Cash Balances

$80 \quad 2,864$

Marketable Securities

$71,166 \quad 132,742$

Securities Purchased Under Agreements to Re-sell

$34,930 \quad 26,616$

Securities Lending

517

480

Total Interest Income from Foreign Currency Financial Assets

$108,731 \quad 166,891$

Interest Income from Local Currency Financial Assets

Securities Purchased Under Agreements to Re-sell

$168,077 \quad 125,161$

Investment Portfolio - NZ Government Securities

$218,174 \quad 197,916$

Advances to Staff

Total Interest Income from Local Currency Financial Assets

Total Interest Income from Financial Assets

29. Interest Expense on Financial Liabilities

Interest Expense on Foreign Currency Financial Liabilities

Securities Sold Under Agreements to Repurchase

Term Liabilities

$3,247 \quad 4,196$

Total Interest Expense on Foreign Currency Financial Liabilities

$137,969 \quad 154,864$

Interest Expense on Local Currency Financial Liabilities

Government Deposits

$141,216 \quad 159,060$

Other Deposits

$199,699 \quad 111,326$

Total Interest Expense on Local Currency Financial Liabilities

$5,450 \quad 6,135$

Total Interest Expense on Financial Liabilities

$205,149 \quad 117,461$

$346,365 \quad 276,521$ 


\section{Gain/Loss from Market Value Changes}

Market value changes arise when financial instruments that are measured at fair value are revalued for changes in the market interest rates.

$\begin{array}{ll}2003 & 2002 \\ \$ 000 & \$ 000\end{array}$

Market Value Changes - Financial Assets

(Loss) Gain from Unrealised Market Value Changes

$21,839 \quad(22,574)$

Gain from Realised Market Value Changes

Total Gain from Market Value Changes from Financial Assets

28,192

Market Value Changes - Financial Liabilities

Loss from Unrealised Market Value Changes

$32,998 \quad 30,419$

Loss from Realised Market Value Changes

18,344

16,341

Total Loss from Market Value Changes on Financial Liabilities

51,342

46,760

\section{Net Foreign Exchange Revaluation Gain (Loss)}

Foreign Exchange Revaluations

Gain (Loss) on Financial Assets

$(471,881) \quad(623,321)$

Gain (Loss) on Financial Liabilities

472,368

624,851

Net Foreign Exchange Revaluation Gain (Loss)

1,530

\section{Other Income}

\begin{tabular}{lrrr} 
& Actual & Budget & Actual \\
& 2003 & 2003 & 2002 \\
& $\$ 000$ & $\$ 000$ & $\$ 000$ \\
\hline Fees for Registry and Depository Services & 5,081 & 4,875 & 5,162 \\
Sales of Collectors' Currency & 349 & 431 & 897 \\
Rental Income from Properties & 1,552 & 1,566 & 1,979 \\
Registered Bank Fees & 10 & 23 & 10 \\
Overseas Investment Commission Fees & 821 & 799 & 853 \\
Miscellaneous & 1,495 & 1,287 & 1,433 \\
Total Other Income & 9,308 & 8,981 & 10,334
\end{tabular}


33. Asset Management Expenses

\begin{tabular}{|c|c|c|c|c|}
\hline & Note & $\begin{array}{r}\text { Actual } \\
2003 \\
\$ 000\end{array}$ & $\begin{array}{r}\text { Budget } \\
2003 \\
\$ 000\end{array}$ & $\begin{array}{r}\text { Actual } \\
2002 \\
\$ 000\end{array}$ \\
\hline Depreciation of Property, Plant and Equipment & 6 & 2,410 & 2,376 & 2,941 \\
\hline Finance Charges Relating to Finance Leases & & 5 & - & - \\
\hline (Gain) Loss on Disposal of Fixed Assets & & $(2)$ & - & 15 \\
\hline Other Asset Management Expenses & & 1,579 & 1,670 & 2,036 \\
\hline Total Asset Management Expenses & & 3,992 & 4,046 & 4,992 \\
\hline
\end{tabular}

\section{Other Operating Expenses}

\begin{tabular}{|c|c|c|c|c|}
\hline & Note & $\begin{array}{r}\text { Actual } \\
2003 \\
\$ 000\end{array}$ & $\begin{array}{r}\text { Budget } \\
2003 \\
\$ 000\end{array}$ & $\begin{array}{r}\text { Actual } \\
2002 \\
\$ 000\end{array}$ \\
\hline Other Professional Fees & & 3,548 & 4,161 & 3,595 \\
\hline Computer Expenses & & 1,430 & 1,715 & 1,499 \\
\hline Information & & 1,037 & 1,076 & 1,026 \\
\hline Operational Travel & & 696 & 839 & 752 \\
\hline Rental and Lease Expenses & & 325 & 321 & 366 \\
\hline Printing & & 184 & 227 & 207 \\
\hline Agency and Commissions & & 1,532 & 1,588 & 1,386 \\
\hline Audit Fees & & 144 & 144 & 144 \\
\hline Non-Executive Directors' Remuneration & 35 & 104 & 131 & 105 \\
\hline Donations & & - & - & - \\
\hline Bad Debts & & 6 & - & - \\
\hline M iscellaneous & & 97 & 310 & 219 \\
\hline Total Other Operating Expenses & & 9,103 & 10,512 & 9,299 \\
\hline
\end{tabular}

Other Professional Fees include $\$ 45,000$ (2002 $\$ 28,000$ ) paid to the Reserve Bank's auditors for audit services in addition to the audit fee and $\$ 5,000(2002 \$ 31,000)$ paid to the Reserve Bank's auditors for work undertaken outside their capacity as auditors of the Bank.

In March 2002, the Bank policy was changed so that the auditors are not engaged for any work other than work related to the provision of an external audit opinion, except after seeking the advice of the Chair of the Audit Committee and with the prior approval of the Governor. 
35. Non-Executive Directors' Remuneration

$\begin{array}{rr}\text { Remuneration } & \text { Remuneration } \\ 2003 & 2002 \\ \$ 000 & \$ 000\end{array}$

Non-Executive Directors

G Simpson (to 8 June 2002)

$\begin{array}{rr}- & 14 \\ 15 & 15 \\ - & 10 \\ 9 & 15 \\ 15 & 15 \\ 15 & 15 \\ 15 & 15 \\ 15 & 5 \\ 15 & 1 \\ 5 & - \\ 104 & 105\end{array}$

A Paterson

$\checkmark$ Hall (to 28 February 2002)

W Wilson (to 31 January 2003)

R Richardson

J Goulter

$P$ Baines

A Grimes (from 1 March 2002)

H Fletcher (from 10 June 2002)

Rt. Hon E Thomas (from 1 March 2003)

Total Non-Executive Directors' Remuneration

002

Non-Executive Directors' Remuneration consists of director's fees. Director's fees represent consideration for services provided to the Bank for acting as a director of the Bank. There are no fees paid to the executive directors of the Bank.

\section{Other Notes}

\section{Reconciliation of Operating Cash Flows with Reported Operating Surplus}

\begin{tabular}{|c|c|c|}
\hline & $\begin{array}{l}2003 \\
\$ 000\end{array}$ & $\begin{array}{l}2002 \\
\$ 000\end{array}$ \\
\hline Reported Operating Surplus & 189,100 & 175,006 \\
\hline \multicolumn{3}{|l|}{ Add (Subtract) Non-Cash Items } \\
\hline Depreciation & 2,410 & 2,941 \\
\hline Amortisation of Premium/Discount on Purchase of Securities & $(28,926)$ & $(57,315)$ \\
\hline Net Unrealised Market Value Changes ${ }^{11}$ & $(9,509)$ & 17,041 \\
\hline Currency Write-Off & 69 & - \\
\hline \multirow[t]{2}{*}{ Net Unrealised Foreign Exchange (Gain) Loss } & $(329,129)$ & $(324,161)$ \\
\hline & $(365,085)$ & $(361,494)$ \\
\hline \multicolumn{3}{|l|}{ Add (Subtract) Movements in Other Working Capital Items } \\
\hline (Increase)/Decrease in Accounts Receivable & 361 & (874) \\
\hline Decrease in M iscellaneous Liabilities & $(601)$ & $(5,019)$ \\
\hline Decrease in Inventories & $(2,106)$ & 983 \\
\hline Decrease in Interest Payable & $(15,757)$ & $(20,357)$ \\
\hline \multirow[t]{2}{*}{ Decrease in Interest Receivable } & $(9,642)$ & 29,159 \\
\hline & $(27,745)$ & 3,892 \\
\hline \multicolumn{3}{|l|}{ Add (Subtract) Investing and Financing Activities } \\
\hline Net Realised Foreign Exchange (Gain) Loss & 328,642 & 322,631 \\
\hline Net Realised Market Value Changes & 11,991 & $(16,559)$ \\
\hline \multirow[t]{2}{*}{ Return of Demonetised Coin } & 2 & 2 \\
\hline & 340,635 & 306,074 \\
\hline Net Cash Flow from Operating Activities & 136,905 & 123,478 \\
\hline
\end{tabular}


37. Consolidated Cash Balances

Foreign Currency Assets

Cash Balances with Other Central Banks

$67,465 \quad 186,025$

Other Cash Balances

$1,738 \quad 6,223$

Marketable Securities - Liquifiable Within Two Working Days

$1,643,142 \quad 1,532,330$

Local Currency Assets

Cash on Hand

\begin{tabular}{rr}
4 & 4 \\
\hline $2,120,364$ & $2,818,939$ \\
\hline $3,832,713$ & $4,543,521$ \\
\hline
\end{tabular}

Demand Liabilities

Government Deposits

$3,142,296$

$2,945,860$

Settlement Bank Deposits

1,815

4,387

Central Bank Deposits

13,625

1,917

International Monetary Fund Deposit

6,963

8,163

Other Deposits

327

206

$3,165,026$

$2,960,533$

Closing Cash Balances ${ }^{12}$

$667,687 \quad 1,582,988$

\section{Statement of Commitments}

\section{Capitalised finance lease commitments}

The Bank leases computer equipment under non-cancellable finance leases. The payments are determined at the beginning of the lease agreements and remain constant during the term of the lease. There are no terms of renewal or purchase options attached to the lease agreements. There are no further restrictions imposed by the agreements such as dividends, additional debt and further leasing.

$\begin{array}{rr}2003 & 2002 \\ \$ 000\end{array}$

Computer equipment

- Due within one year

\begin{tabular}{|c|c|}
\hline 133 & - \\
\hline 112 & - \\
\hline 55 & - \\
\hline 300 & - \\
\hline 10 & - \\
\hline 310 & - \\
\hline 140 & - \\
\hline 170 & - \\
\hline 310 & - \\
\hline
\end{tabular}

12 The movement in closing cash balances largely arises from the increase in foreign currency assets of $\$ 1.1$ billion arising from Market Operations. These foreign currency assets are not classified as cash in the Consolidated Statement of Cash Flows. 


\section{Operating Lease Commitments}

The Bank leases office equipment under operating leases. The payments are determined at the beginning of the lease agreements and remain constant during the term of the lease.

Office equipment

- Due within one year

\begin{tabular}{rr}
171 & 359 \\
33 & 181 \\
23 & 24 \\
\hline 227 & 564
\end{tabular}

Total operating lease commitments

\begin{tabular}{rr}
1,120 & 2 \\
3,070 & 4,727 \\
\hline 4,190 & 4,729
\end{tabular}

Total capital expenditure commitments

\section{(20)}

Lease Payments Receivable

The Bank owns its head office in Wellington and leases out seven of the fourteen floors to tenants under operating leases. Under the current non-cancellable lease agreements, the total minimum lease payments receivable are as follows.

\begin{tabular}{llr} 
& 2003 & 2002 \\
& $\$ 000$ & $\$ 000$ \\
\hline - Receivable within one year & 1,384 & 1,384 \\
- Receivable within one to five years & 3,466 & 4,460 \\
- Receivable later than five years & 1,434 & 1,823 \\
Total lease payments receivable & 6,284 & 7,667 \\
\hline
\end{tabular}

\section{Subsidiary Companies}

The Reserve Bank has two wholly-owned New Zealand-incorporated subsidiaries, RBNZ Registry Limited and New Zealand Central Securities Depository Limited (NZCSD).

Up to 30 June 2001, RBNZ Registry Limited provided the Bank's Registry and Depository Services function under an agency agreement with the Bank. Since 1 July 2001 these services have been provided directly by the Bank. RBNZ Registry Limited ceased trading on 30 June 2001 and is being wound up.

NZCSD is a non-trading company, incorporated solely for the purpose of acting as a custodian trustee. It holds assets on behalf of the participants in the Austraclear New Zealand System, as described in note 44.

\section{Free Services}

The Reserve Bank of New Zealand Act 1989 empowers the Bank to charge directly for some of its functions.

Some services are provided free of charge. These include providing information to Ministers and Parliament, contributing to policy and briefing papers, providing information to the public, storing official documents securely, and providing information and library facilities to parties such as government departments and economic research organisations.

The Bank receives some free services from other organisations, generally involving the provision of information.

The Bank liaises closely with other central banks and international agencies. Information and staff training are exchanged free of charge with these institutions. 


\section{Related Parties}

In the normal course of its operations, the Reserve Bank enters into transactions with related parties. Related parties include the Crown, as ultimate owner of the Bank, various government departments, and Crown entities.

Transactions entered into include:

- banking services;

- agency transactions (at no charge);

- foreign exchange transactions;

- funding from the Treasury as part of the foreign reserves management operations; and

- purchases of New Zealand government securities.

The Bank does not disclose the values of transactions and outstanding balances with Crown-related parties due to the large volume of transactions and the large number of related parties. Unless otherwise stated, all transactions take place with reference to market rates. Therefore, disclosure of the values of transactions and outstanding balances with Crown entities would not provide useful or material additional information.

\section{Contingent Liabilities}

(a) In terms of a Trust Deed dated 16 May 1980, the Reserve Bank has a contingent liability to maintain the actuarial soundness of the Reserve Bank of New Zealand Staff Superannuation and Provident Fund, following each triennial review of the Fund.

On 2 February 1995, the Bank ceased making contributions to the defined benefit division of the Fund on the advice of the Fund's Actuary that such contributions were no longer necessary. The position is re-examined as part of each triennial review (last completed for the period ended 31 March 2002).

The Actuary carried out a limited scope investigation into the financial position of the Fund as at $31 \mathrm{M}$ arch 2003 and reported on 8 July 2003 that, based on the Fund's annual accounts:

- The assets of the Fund were sufficient at 31 March 2003 to meet the benefits obligations in respect of all members, including existing pensioners, in the event of the Fund being wound up at that time.

- The assets of the Fund were sufficient at $31 \mathrm{M}$ arch 2003 to provide for benefits to members, including existing pensioners, that are attributable to membership prior to 1 April 2003. In assessing the expected cost of those benefits the Actuary allowed for appropriate provisions for future salary growth in respect of active members and increases in the Consumer Price Index for pensioner members.

- That it is appropriate for the Bank to continue its contribution holiday.

- To the Actuary's knowledge, there had been no circumstances between $31 \mathrm{M}$ arch 2003 and 30 June 2003 that would cause the Actuary to form a different opinion as at 30 June 2003.

(b) Coin issued by the Treasury prior to July 1989 is not recorded by the Bank within the total of currency in circulation. The Bank has accepted liability for all coin in the first instance, whether issued by the Treasury or the Bank. However, should coin returned to the Bank exceed that issued by the Bank, the liability for the excess would revert to the Treasury. The face value of coin issued by the Treasury is $\$ 87.6$ million (2002 \$87.7 million).

(c) The Bank has a contingent liability for currency in circulation that has been demonetised but not returned to the Bank. The face value of demonetised currency is $\$ 37.1$ million (2002 $\$ 37.1$ million). This includes coin issued by Treasury with a face value of $\$ 12.9$ million (2002 $\$ 1.3$ million). 
(d) The Bank has a liability for the face value of collectors' currency. However, it is most unlikely that significant amounts of collectors' currency will be returned for redemption at face value. The face value of all collectors' currency issued by the Bank to date is $\$ 9.3$ million (2002 $\$ 9.0$ million).

Collectors' coin was issued by the Treasury prior to July 1989. Particular specimens of series issued both before and after 1989 are not generally distinguishable. The Bank has in practice accepted a contingent liability for all collectors' coin, but part of this liability could revert to the Treasury should large quantities of coin be returned.

(e) The Bank has indemnified the statutory managers of DFC New Zealand Limited against liability arising from the statutory management of DFC New Zealand Limited, which essentially ended on 15 October 1997. However, these indemnities continue and were given under sections 5 and 39 of the Reserve Bank of New Zealand Act 1989, on substantially the same terms as those provided by the Crown under Part $\mathrm{V}$ of the Act.

\section{Previous Year's Contingent Liabilities}

The above five contingent liabilities were recorded in the Reserve Bank's 2002 Annual Report. The only liabilities to arise during the year were:

- Demonetised currency with a face value of $\$ 34,000$ returned to the Bank for redemption at face value.

- Collectors' currency with a face value of $\$ 686$ returned to the Bank for redemption at face value.

\section{Income Tax}

Section CB3 of the Income Tax Act 1994 exempts the Reserve Bank from income tax. The Bank incurs and meets liabilities for goods and services tax, fringe benefit tax and other withholding tax.

Until 30 June 2001, the Bank provided Registry and Depository Services through its wholly-owned subsidiary RBNZ Registry Limited. The subsidiary was liable for income tax on its net earnings. From 1 July 2001, these services were provided directly by the Bank, which, as stated above, is exempt from income tax.

\section{Custodial Activities}

The Reserve Bank operates the Austraclear New Zealand System, which is a securities clearing and settlement system. It holds assets, on behalf of the participants, in the name of New Zealand Central Securities Depository Limited (NZCSD), which it has appointed as custodian trustee in terms of the Trustee Act 1956.

NZCSD is a wholly-owned subsidiary of the Bank, which, in terms of a Deed of Appointment between the Bank and NZCSD, is incorporated solely for the purpose of acting as a custodian trustee. NZCSD is a non-trading company but has legal ownership of securities beneficially owned by members of the Austraclear system. With the exception of the local currency securities owned by the Bank and held through NZCSD, the Bank has no beneficial interest in the securities that NZCSD holds, or any management obligations apart from safe-keeping or acting as paying agent in certain circumstances.

The total of securities held by NZCSD at 30 June 2003 was $\$ 77.2$ billion (2002 $\$ 74.2$ billion).

The Bank undertakes to accept liability for all costs and debts of NZCSD and all liabilities of NZCSD in the event of a claim by a third party. No claims have been notified or advised at balance date. 


\title{
IAS 39 Financial Instruments: Recognition and Measurement
}

\author{
(Effective January1, 2005) $^{21}$
}

\section{A. Introduction}

IAS 39 establishes standards for recognizing and measuring information about an entity's financial assets and financial liabilities. IAS 39 provides clear rules on the circumstances where amortized cost or fair value accounting for financial instruments may be applied. IAS 39 and IAS 32 are the two main standards pertaining to financial instruments. IAS 39 has no disclosure requirements, and it is beyond the scope of this appendix to consider and resolve all the issues involved in applying IAS 39 to central bank circumstances. Therefore, the appendix provides an outline of some of the key requirements of IAS 39 and outlines issues to consider in its application to central banks.

\section{B. Recognition}

A financial asset or a financial liability is recognized by an entity on its balance sheet when the entity becomes a party to a contract. The following are some examples:

- the entity has a legal right to receive, or a legal obligation to pay, cash; or

- goods and services have been delivered or rendered; or

- a commitment has been made to purchase or sell a financial asset on a future date at a specified price by a regular way purchase or sale.

\section{Categories of financial assets}

IAS 39 identifies four categories of financial assets. These are:

1. Financial assets at fair value through profit or loss. This includes:

- Financial assets classified as held for trading assets, which are generally assets, acquired to generate a profit from short-term fluctuations in price. Derivatives are classified as held for trading unless they are designated an effective hedging instrument.

- Financial assets that are designated by the entity as fair value through profit or loss.

2. Held-to-maturity investments are non-derivative financial assets with fixed payments and fixed maturity that the entity intends and is able to hold to maturity.

21 Prepared by Janet Cosier and Kenneth Sullivan. 
3. Loans and receivables are nonderivative financial assets with fixed payments that are not quoted in an active market.

4. Available-for-sale assets are non-derivative financial assets that are designated as available-for-sale or are not classified within the three other categories.

When classifying assets for valuation under IAS 39, central banks need to make decisions reflecting the nature of the asset, the reason for holding it, the nature of any liability it is offsetting, the need to trade the asset against the intention to hold it to maturity, and the profit distribution framework for the bank. IAS 39 limits the scope to transfer assets between categories, since the definitions have been tightened and the available alternative treatments reduced. The presumption now is for a move to fair value accounting with limited exemptions. Fair value captures changes in the value of financial assets in the period they occur, potentially creating greater volatility in the measurement of a bank's income. Consequently, management of the income statement will require more careful attention to the central bank's balance sheet.

\section{Trade date versus settlement date}

A "regular way" purchase or sale of financial assets should be recognized in the accounting records using trade date accounting or settlement date accounting. The method used is applied consistently for all purchases and sales of financial assets that belong to the same category as outlined above. For this purpose, assets that are held for trading form a separate category from assets designated at fair value through profit and loss.

The trade date is the date an entity commits to purchase or sell an asset. It is the date the entity recognizes the asset to be received and the liability to pay in the future and derecognizes an asset that is sold and recognizes the receivable from the buyer. When the entity uses trade date accounting for financial assets measured at fair value, it will account for any change in the fair value of the assets during the period between the trade date and the settlement date.

The settlement date is the date that the asset is delivered to or by an entity.

\section{Measurement}

\section{Initial measurement of financial assets and financial liabilities}

A financial asset or financial liability is recognized initially by an entity at cost, which is the fair value given for the asset or the fair value received in the case of a liability.

The cost is determined by the transaction price and for financial assets and liabilities, other than those at fair value through profit or loss, includes any transaction costs for fees and commissions paid to agents, brokers, and dealers. 


\section{Subsequent measurement of financial assets}

After initial recognition, financial assets should be measured at their fair values except for the following categories:

- loans and receivables;

- held-to-maturity investments; and

- investments in equity instruments that do not have a quoted market price in an active market, and whose fair value cannot be reliably measured.

The published price quotations in an active market are the best evidence of fair value. However, if the market for a financial instrument is not active, an entity establishes fair value using a valuation technique. Valuation techniques include using recent arm's length market transactions, reference to the current fair value of another instrument that is substantially the same, discounted cash flow analysis and option pricing models. Where a valuation technique is commonly used by market participants to price the instrument and that technique has been demonstrated to provide reliable estimates of prices obtained in actual market transactions, the entity will use that technique.

\section{Financial liabilities}

Financial liabilities designated as fair value through profit or loss shall be measured at their fair value. All others are valued at amortized cost.

\section{Gains and losses}

Fair value through profit or loss. A gain or loss on a financial asset or financial liability classified as at fair value through profit or loss shall be included in profit or loss.

Available-for-sale financial assets. A gain or loss on an available-for-sale financial asset shall be recognized directly in equity, through the statement of changes in equity, except for impairment losses and foreign exchange gains and losses, which one included in profit and loss.

Financial assets and financial liabilities carried at amortized cost. For financial assets and liabilities carried at amortized cost, a gain or loss is recognized in profit or loss when the financial asset or financial liability is derecognized or impaired when there is objective evidence that an impairment loss has been incurred. Impairment losses are measured as the difference between the asset's carrying amount and the present value of expected future cash flows discounted at the financial asset's original effective interest rate. To recognize the loss, the carrying value of the asset should be reduced to the estimated recoverable amount either directly or through the use of an allowance account. The amount of the loss should be recognized in profit or loss.

The following table summarizes the accounting treatment for measuring financial assets and financial liabilities. 


\begin{tabular}{llll}
\hline Category & Initial Measurement & $\begin{array}{l}\text { Subsequent } \\
\text { Remeasurement }^{22}\end{array}$ & $\begin{array}{l}\text { Gain or Loss on } \\
\text { Remeasurement } \\
\text { Reported in }\end{array}$ \\
\hline $\begin{array}{l}\text { Fair value through } \\
\text { profit or loss }\end{array}$ & Fair value (cost) & Fair value & Profit and loss \\
$\begin{array}{l}\text { Available-for-sale } \\
\text { Held-to-maturity }\end{array}$ & Fair value (cost) & Fair value & Equity \\
$\begin{array}{l}\text { Loans and } \\
\text { receivables }\end{array}$ & Fair value (cost) & Amortized cost & $\begin{array}{l}\text { Profit and loss for } \\
\text { impairment }\end{array}$ \\
\hline
\end{tabular}

\section{Managing Income}

\section{Selecting appropriate asset classifications}

One option to reduce income volatility is to classify assets, where appropriate, as being held to maturity. This removes the need to record them at fair value (though fair value disclosure is still required in the notes to the accounts). This will reduce the size of unrealized revaluation gains reported through profit and loss and the related volatility. While the held-to-maturity facility is designed to satisfy the needs of specific types of financial institutions who hold assets to meet specific future liabilities, there is some rationale for central banks to adopt this position for that portion of their portfolio that backs the currency in circulation liability. As a zero-rated liability, the currency in circulation liability has no offsetting valuation movements when interest rates change.

To comply with the held-to-maturity requirements central banks will need to be careful to ensure the criteria of the category it complies with. This may require the division of like securities into separate portfolios to enable differing valuations to be applied to the same security type that may be held for differing purposes. However, it should be noted that IAS 39 prohibits an entity classifying any assets as held to maturity if is sells or transfers more than an insignificant amount of held-to-maturity investments before maturity during the current financial year or during the two preceding financial years. ${ }^{23}$

\footnotetext{
${ }^{22}$ Fair value is calculated by published quotations in an active market or using a valuation technique where there is no active market.

${ }^{23}$ The are limited circumstances where a sale does not trigger this outcome outlined under IAS 39.
} 
An alternative option to minimize the impact of fair value on income is by using the availablefor-sale (AFS) classification. The gains and losses on AFS financial assets will not be recognized through profit and loss (with the exception of any foreign currency gains and losses which will be recognized in income under IAS 21).

\section{Impact of classifications on income and reserves}

The decision to classify an asset as AFS with unrealized revaluation gains and losses recognized directly in equity raises interesting questions of managing central bank income and the effect of unrealized losses on the central bank's equity. Taking the revaluations to reserves will reduce the volatility of reported profit. In times of falling interest rates, this will result in a growth of reserves and an effective understatement of economic income. The effect will be to reduce the pool of dividends payable to the government.

Conversely, in a situation of rising interest rates the opposite result will occur. The reserves will accumulate debit balances, eroding capital, while the reported profit will be effectively overstated. The profit for distribution to the government will not be reduced by the amount of the revaluation losses. The result, if the AFS quantity is significant, could be a situation where the government is receiving large profit disbursements from the central bank while it is showing a notional negative capital position. As entities are unable to switch between alternate treatments as circumstances change, central banks will need to think through the issues very carefully regarding what assets they classify as available-for-sale.

Traditionally accounting standards have avoided the maintenance of debit balances within equity accounts. Prudence and the capital maintenance concept required that debit balances should be accounted for through the income statement so to ensure that reductions of capital were resolved before any distributions of dividends occurred. This was reflected in the expectation that where revaluation accounts are maintained they may only exist if they have a credit balance. In the event that the credit balance is written down, any further revaluation losses were to be taken into the income statement. 


\section{Impairment of financial assets}

IAS 39 requires recognition of impairment losses on financial assets at amortized cost through profit and loss. A financial asset is impaired if its carrying amount exceeds its estimated recoverable amount. The recoverable amount must be estimated if objective evidence exists that suggests an asset is impaired. The excess of carrying amount over the estimated recoverable amount is an impairment loss and is included in profit and loss. The standard discusses the need to recognize impairment of asset values on an individual basis for significant items or on a group basis for minor or residual items. Impairment of financial assets is recognized either through direct write-downs to expenses or indirectly through provisions. Either way the requirement is to report the changes in value arising from impairment through profit and loss. Besides the direct impact that this will have on income recognition, there is now an increased duty to ensure that the loan portfolio is properly managed, valued, and losses provided for. Compliance with IFRS now requires the ability to demonstrate that this management of the loan portfolio is happening.

This strengthened requirement for reporting impairment of loans will assist bank supervisors to develop an appropriate provisioning regime among commercial banks that should be complying with IFRS as a minimum.

This will pose some problems for a number of central banks because of their holdings of nonperforming government debt. A strict adherence to international standards requires the continued accrual of interest on this debt until it is deemed nonperforming. Once it is deemed nonperforming it is possible to stop accruing interest on it but the need then exists to make provisions for its impairment. The problem with a central bank writing off government debt is that it is equivalent to publicly acknowledging government insolvency. While this is politically inexpedient, the alternatives are limited if one wishes to remain in compliance with IFRS. There are obvious incentives here to ensure that governments maintain the integrity of their financial obligations.

The main impact of IAS 39 on profit and loss lies in the move to a wider application of fair value valuation methodology and the consequential requirement to report the majority of these valuation changes through profit and loss. Consequently, central banks will need to pay close attention to the income effects of these changes. Financial assets at fair value through profit and loss must be valued at fair value and the valuation changes taken to income. Holding large portfolios of tradable securities could result in potentially large valuation impacts in profit and loss, especially where no offsetting liabilities exist. This will be problematic if the central bank is unable to exclude unrealized revaluation gains from distribution as dividends. Even if it is able to remove these unrealized gains from distribution, they could introduce volatility to reported income that could result in criticisms of the quality of central bank management. This is particularly so given that central banks are among the architects of the very movements in interest rates that cause the changes in values of the securities. The standard removes the discretion to hold securities for trading but value them at cost or lower of cost and market. The challenge for central banks is to ensure that their balance sheet is appropriately classified so that unnecessary volatility is avoided and the volatility that does occur can be explained. 


\section{E. Other IAS 39 Requirements}

IAS 39 includes several other measurement and recognition requirements including embedded derivatives and hedge accounting. These are briefly outlined in this section.

\section{Embedded derivatives}

IAS 39 contains additional special rules for financial instruments that contain an embedded derivative. This is a derivative contract that is embedded in another contract - the host contract. Examples include convertible debt and prepayment options in mortgages. This requirement is designed to ensure that the recognition of derivatives cannot be avoided by including (embedding) a derivative in a another contract or financial instrument that is accounted for on a different basis to the derivative.

An embedded derivative is required to be separated from its host contract and accounted for separately when its economic characteristics and risks are not closely related to the economic characteristics and risks of the host contract. However, an embedded derivative that is included in a financial asset or liability that is measured at fair value with changes recognized in profit and loss does not have to be separated and measured because the changes in value will be included in the changes of the combined instrument and reported through profit and loss.

\section{Hedge accounting}

A significant part of IAS 39 is devoted to detailed rules in relation to the application of hedge accounting. In the absence of applying the hedge accounting rules, all derivative financial instruments must be reported at fair value with the gains and losses recognized directly through profit and loss.

Hedge accounting means designating a hedging instrument, normally a derivative, as an offset to changes in the fair value or cash flows of a hedged item. Nonderivative financial instruments may be used as hedging instruments only in respect of foreign exchange risk. A hedged item can be a recognized asset or liability, an unrecognized firm commitment, a highly probable forecast transaction or a net investment in a foreign operation. Hedge accounting attempts to match the offsetting effects of the hedged items and hedging instrument and recognize them through profit and loss at the same time.

IAS 39 outlines the criteria under which hedge accounting may be applied. The hedge accounting criteria are only permitted when:

- The hedging relationship is formally designated and documented including identification of the hedging instrument, hedged item, the nature of the risk being hedged, and how the entity will assess the effectiveness of the hedge.

- The hedge is expected to be highly effective and the effectiveness of the hedge can be reliably measured and tested. 
The measurement rules under hedge accounting depend on whether the hedge is considered a fair value hedge or a cash flow hedge, and IAS 39 requires differing treatment depending hedge characteristics.

\section{F. Summary}

IAS 39 creates a number of challenges for central banks. These include the classification of financial assets and the application of the complex hedge accounting rules. Central banks will need to carefully plan the application of IAS 39 in conjunction with consideration of the impact on reported equity and distributions of central bank profits. This may require both education of politicians and users of central bank financial statements as to the impact of IAS 39 as well as the development of a robust dividend distribution policy to ensure that central bank capital is not endangered through the distribution of unrealized profits. 


\section{IAS 21-The Effect of Changes in Foreign Exchange Rates ${ }^{24}$}

\section{A. Introduction}

This standard, while significant in determining how central banks record and value foreign currency transactions within their accounts, has relatively limited effect on the disclosure requirements for a central bank. For central banks, the usual manager of a nation's foreign exchange reserves, IAS 21 is an important standard. This appendix will summarize the significant accounting treatments prescribed by this standard for central banks and discuss the treatment of foreign exchange revaluation gains and losses before closing, with a summary of the disclosure requirements required under this standard.

\section{B. Required Treatment under IAS 21}

All foreign exchange transactions undertaken by the central bank should be recorded at the exchange rate prevailing at the time of the transaction.

Subsequent revaluations of the transactions at the end of the period depend on whether the foreign currency item is classified as a monetary or nonmonetary item.

Monetary items, defined as "money held and assets and liabilities to be received or paid in fixed or determinable amounts of money,",25 are to be revalued at balance sheet dates using the exchange rates prevailing on that date. Nonmonetary items, which are everything else, are not revalued and are reported at the exchange rate prevailing at the time of the transaction.

\section{Treatment of Revaluation Gains and Losses}

IAS 21 requires all gains and losses on monetary items, both realized and unrealized, to be reported through profit and loss. ${ }^{26}$ Because of its special role in managing a country's foreign reserves, a central bank often carries significant open foreign exchange positions that can result in large movements of unrealized revaluation gains and losses. Ideally, the central bank should be able to recognize these revaluation movements in profit and loss but exclude them from considerations of taxable income or for distribution to the government as dividends. This is achieved by allocating them to an unrealized revaluation reserve before arriving at distributable earnings.

Unrealized losses reported through profit and loss could be offset against unrealized revaluation reserves. In the situation where the losses continue once the revaluation reserve has reached a zero balance, the continued accumulation of losses in this reserve will create debit balances that will have the effect of eroding the capital of the bank. This raises a second issue of concern.

\footnotetext{
24 Prepared by Kenneth Sullivan.

25 IAS 21, para. 8. Note that this does not include monetary gold.

${ }^{26}$ IAS 21, para. 28.
} 
Any charge from operations that has the effect of reducing the capital of the bank should be included and disclosed through profit and loss. This is very important because it allows the bank to offset losses against gains before it makes any distributions to the government's budget. The result is that the bank first applies its net income to maintain its capital value before deciding any distributions.

The automatic accumulation of losses in a revaluation reserve means that the financial statements may not disclose them to bank management, and they may not gain attention until they have seriously eroded the bank's statutory capital and other reserves. This practice will accelerate the erosion of the bank's capital because, at the same time that the debit balance is accumulating in the revaluation reserve, the bank is undertaking distributions of income to the government's budget. This is the same concern as expressed when discussing AFS assets under IAS 39.

A common feature in transition economies is the accumulation of large foreign-currencydenominated liabilities as the nation borrows to stabilize its balance of payments situation. Pressures to devalue the currency usually accompany this. The combination of these two situations produces revaluation losses. To reduce the impact of this on the central bank's capital they need to be reported through profit and loss rather than assigned to a revaluation reserve.

The provisions of IAS 39 and IAS 21 are different. IAS 39 allows the accumulation of unrealized revaluation gains and losses in reserves for AFS assets without being reported through profit and loss, while IAS 21 requires all revaluation movements to be reported through profit and loss. Best practice remains the adoption of fair value and recognition through profit and loss at the time of revaluation.

\section{Disclosure Requirements under IAS 21}

The relevant disclosure requirements for central banks relating to holdings of foreign exchange reserves are the:

- amount of exchange differences included in the profit or loss for the period; and

- net exchange differences classified as equity as a separate component of equity, and a reconciliation of the amount of such exchange differences at the beginning and end of the period.

A significant disclosure requirement for a central bank that is not found in IAS 21 is the requirement in IAS 30 that a "bank should also disclose the amount of significant net foreign currency exposures." 27

Given that central banks usually carry significant levels of foreign currency assets and liabilities, the disclosure requirements of IFRS are inadequate in specifying the full level of disclosures that a reader of a central bank's financial statements would find relevant. Readers would be interested in information about currency composition, the types of assets and liabilities, and the nature and management of foreign currency risk faced by the central bank. An example of an additional disclosure could be a note reconciling the net foreign currency position reported in the balance

${ }^{27}$ IAS 30, para. 40. 
sheet with that reported to the IMF in the statement of net international reserves or through the Special Data Dissemination Standard (SDDS). Such a disclosure is found in the notes to the accounts of the National Bank of Ukraine's financial statements. Other examples of foreign currency holding disclosures can be found in the RBNZ 2003 financial statements included in Appendix II of this publication, in the balance sheet and notes 1, 16, 18, 19, 20, 21, 22, 31, and 37.

There are further disclosure requirements for any entity that holds investments in foreign entities but these are not covered in this appendix because they are a minor issue for only a few central banks. 


\section{Differences between the ACCOUnting ANd Reporting Principles In THE EUROSYSTEM AND THE INTERNATIONAL FINANCIAL REPORTING STANDARDS (IFRS) ${ }^{28}$}

\section{A. Introduction}

The European System of Central Banks (ESCB) is represented by the European Central Bank (ECB) in Frankfurt, Germany, and the 25 National Central Banks (NCBs) participating in the European Union. The Eurosystem consists of the ECB and the 12 NCBs which have adopted the single currency area. For analytical and operational purposes, the ECB must produce a consolidated balance sheet which is an aggregation of the balance sheets of the ECB and the NCBs participating in the Eurosystem. Furthermore, the ECB publishes a consolidated weekly financial statement every Tuesday (after quarter end on Wednesday) reporting the data of the previous Friday.

The statute of the ECB/ESCB requires the Governing Council of the ECB to establish a set of standard rules covering the accounting and reporting of operations undertaken by the central banks participating in the Eurosystem. This ECB Guideline, covering the accounting and reporting regimes, is a legally binding instrument in the European Union. The principles apply to the Eurosystem and therefore are not binding on NCB's national reports and financial accounts. However, in order to achieve consistency and comparability it is recommended that NCBs should, to the extent possible, adopt these rules, which almost all of the participating NCBs have done since the beginning of the Eurosystem either by legal obligation or on a voluntary basis.

\section{B. General Remarks}

The ECB Guideline was originally drawn up for a first-time application from 1999 onwards by an ECB committee representing accounting experts from the central banks of the European Union and the ECB. The European Accounting Directives, the IAS, and Generally Accepted Accounting Principles formed the basis for the considerations. The Guideline intended to establish accounting standards that meet both the specific needs of central bank accounting and the financial reporting requirements of the Eurosystem.

As the economic and financial environment is continually evolving, the ESCB has committed itself to monitor the development of accounting and reporting standards and will review the harmonized provisions in light of changing international standards or other operational needs. Thus the latest revision of the ECB Guideline approved on December 5, 2002, has been effective from January 1, 2003.

The ESCB accounting and reporting principles have a very high degree of compliance with IFRS principles. Those limited areas where the ECB Guideline does not fully follow IFRS

${ }^{28}$ Prepared by Mr. Friedrich Karrer. 
are in areas where it was considered that IFRS did not meet specific central bank accounting and reporting requirements. The ECB Guideline focuses on core central bank activities. Therefore, in interpreting this Guideline account shall be taken, amongst other things, of the accounting principles harmonized by EU community law and generally accepted international accounting standards.

The following chapter describes the areas where the ESCB accounting and reporting principles deviate from IFRS. There is no discussion when policies and accounting techniques comply with IFRS or when specific standards of the IFRS framework are not relevant for core central bank activities.

\section{References}

\section{Accruals-Amortization for Securities}

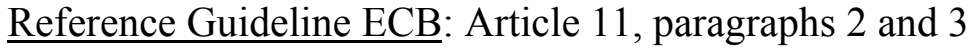

The ESCB gives detailed definitions about the method of calculation, date of calculation and recording in the accounts. The amortization for securities purchased below or above the nominal value is calculated by use of either the straight line or implicit rate of return method, depending on the type and remaining duration of the securities.

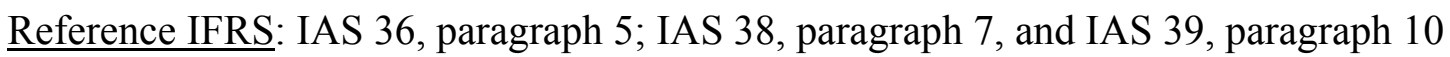

IFRS specifies only terms in accordance with amortization and the basic meanings.

\section{Recognition of Income and Treatment of Unrealized Gains and Losses at Balance Sheet Date}

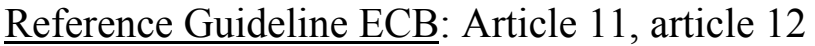

These articles specify a separate treatment for gold, each different currency and each different class of security.

Realized gains and realized losses shall be taken to the profit \& loss account.

Unrealized gains from price or currency revaluation are posted directly to a revaluation account shown as a liability in the balance sheet. These entries are therefore not recognized as income.

Unrealized losses are recorded to the profit and loss account at year-end when exchange rates and market prices fall below average acquisition cost. Unrealized losses transferred to the profit and loss account are not reversed in following years against new unrealized gains. Unrealized losses in one currency or in a security may not be netted against unrealized gains in another currency or security. 
The rationale for this asymmetric treatment is based on the consideration that central banks should not record unrealized gains in the profit and loss account, as they are not seen as distributable until they are realized. Paying dividends by central banks increases liquidity in the financial sector by enlarging the monetary base. Therefore, it is considered inappropriate to distribute unrealized gains as they are not based on a reliable and sustainable increase in the asset side of the central bank's balance sheet. Underpinning the rationale for this approach is the fact that the central banks of the eurosystem hold substantial risky and generally static portfolios of foreign currency and gold, which are held primarily for monetary policy purposes rather than for trading. Consequently, the IFRS philosophy of recognizing changes in the wealth of an entity in its income statement could lead to significant volatility in central bank profits.

Reference IFRS: Framework, paragraphs 74 to 77 (income), 78 to 80 (expense), 81 (Capital Maintenance Adjustment), 102 to 110 Concepts of Capital and Capital Maintenance

Unrealized gains: follows concept of capital maintenance:

Under this concept, a gain is earned only if the financial amount of the net assets at the end of the period exceeds the financial amount of net assets at the beginning of the period (Framework 92 and 94a).

Unrealized losses: Recognition of expenses occurs simultaneously with the recognition of an increase in liabilities or a decrease in assets (Framework 94).

IAS 21, paragraphs13-16 requires all exchange rate revaluation gains and losses to be reported through profit and loss.

IAS 39 provides a range of valuation options depending on the reason for holding the financial instrument.

\section{Accounting Rules for Off-Balance-Sheet Instruments}

Reference Guideline ECB: Article 13 (general rules), article 14 (forward exchange transactions), article 15 (foreign exchange swaps), article 16 (interest futures), article 17 (interest rate swaps), article 18 (forward rate agreements), and article 19 (forward rate transactions in securities).

For all these transactions the ESCB has specified rules how to record the instruments, how to recognize revaluation differences and the treatment of income. All the rules follow the general accounting principles of the ESCB (e.g., revaluation at market values, treatment of realized and unrealized gains and losses, and accruals principle). 


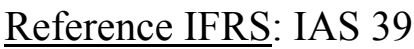

The IFRS are more prescriptive than ESCB standards. IAS 39 requires that all financial assets and liabilities, including derivatives are recorded in the balance sheet. For financial instruments presented at fair value, the treatment of revaluation differences depends on the purpose of holding.

\section{Hedge Accounting}

\section{Reference Guideline ECB: Article 12, paragraph $3 \mathrm{~d}$ (relating to FX and gold)}

For gold and currencies, a macro hedge concept is applied as all assets and liabilities, and contingent claims and contingent liabilities, are aggregated for each currency when calculating net acquisition cost and resulting realized and unrealized effects.

No hedge accounting is allowed for securities or other financial instruments.

\section{Reference IFRS: IAS 39}

IFRS is far more specific than the ECB-Guideline as it allows a greater range of hedging of instruments. It applies strict definition of hedges, hedge effectiveness and requires all hedges to be accounted for at fair value. Hedging in general is dealt within IAS 39 paragraph 121 to 152 while the recognition of gains and losses resulting from hedge relations is covered in paragraph 153 to 164 .

\section{Trade Date versus Settlement Date Accounting}

\section{Reference Guideline ECB: Article 5, Annex III}

The ESCB standards presently allow both trade date or settlement date approaches, provided that financial reporting for the purposes of consolidation is performed adjusted to a settlement basis where relevant. As from 1 January 2007, all NCBs will have to change their accounting systems to trade date recording (economic approach), with the exception of securities transactions. Annex III describes the economic approach in detail.

\section{Reference IFRS: IAS 39}

IAS 39, paragraphs 30-34, discusses this issue but accepts recording a transaction on the trade date or settlement date basis.

\section{Reporting Obligations-Format of Balance Sheet and Profit and Loss Account}

Reference Guideline ECB: Annex I list the types of financial statements in the Eurosystem, both internal and published. Annex IV relates to the composition of the balance sheet and 
determines the content of balance sheet items and valuation principles. The formats are laid down as follows:

- Annex V: Consolidated weekly financial statement of the Eurosystem: format to be used for publication after quarter end

- Annex VI: Consolidated weekly financial statement of the Eurosystem: format to be used for publication during the quarter

- Annex VII: Consolidated annual balance sheet of the Eurosystem

- Annex VIII: Annual balance sheet of a central bank

- Annex IX: Published profit and loss account of a central bank

\section{Reference IFRS: IAS 30}

- Weekly financial statements are not specified in IFRS. (The Eurosystem publishes them due to a specific requirement of its statute.)

- Annual balance sheet and annual consolidated balance sheet have a completely different format in comparison to the ESCB rules

- The ESCB-format of the profit and loss account is similar to IAS 30

The format of the Eurosystem's weekly financial statement and the annual balance sheet was created to provide the user with a clear picture of the Eurosystem-related ECB monetary policy decisions. The format is structured according to the monetary policy instruments established by the Eurosystem as well as to identify the principal asset and liability groups denominated in gold, foreign currency or in euro. Presentation incorporates a split between assets and liabilities that are held against residents or non-residents of the euro area.

\section{Reporting Obligations-Other Financial Reporting Formats}

- Statement of changes in equity

- Cash flow statement

These reports are not required under the ESCB rules though they are required under the annual financial statements according to the IFRS framework (IAS1). The ESCB is of the opinion that these two reports do not give any significant or useful additional information to the other existing financial and statistical information provided within the Eurosystem.

\section{Disclosure Notes to the Annual Accounts}

\section{Reference Guideline ECB: none}

No ESCB regulation exists covering the content of notes to the annual accounts. This means that the NCBs have to follow their own legal requirements that are based on the EC directives. 
Most IFRS contain detailed instructions on what information needs to be disclosed either as accounting policies or within the notes to the annual accounts.

This is a significant, but not irreconcilable, area of divergence between ESCB and IFRS reporting requirements. The tendency within the Eurosystem has been to move voluntarily towards greater transparency, in line with international standards, but without being prescriptive. Harmonized disclosure has been agreed for certain components of the balance sheets of the individual Eurosystem central banks where there are links with the balance sheets of other Eurosystem members.

\section{Impairment}

$\underline{\text { Reference Guideline ECB: }}$ no specific regulation

In the absence of any detailed regulation, the basic accounting assumptions which are stated in Article 3 of the ECB Guideline may provide some guidance in this respect. Otherwise, NCBs follow national guidelines.

\section{Reference IFRS: IAS 36 and 39}

IFRS separated the impairment of financial (IAS 39) and non-financial (IAS 36) assets. Detailed procedures are laid down to ensure that assets are carried at no more than their recoverable amount.

\section{Provision for General Banking Risk}

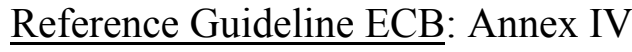

Under the ESCB standards, a creation of provisions for exchange and price risk is not excluded (although national arrangements may restrict or prohibit their creation). Although no specific regulation is contained in the ECB Guideline, Annex IV determines how such a provision - if built by a NCB taking into consideration its individual national legal regimehas to be presented in the balance sheet.

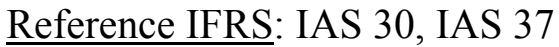

Under IFRS, a provision for general banking risk is not allowed according to IAS 30 Paragraph 50 to 52 and various paragraphs in IAS 37. Under IAS 39, impairment is an incurred loss basis, which prevents the accumulation of ex ante provisions.

This divergence between IFRS and the ESCB rules may be of relevance regarding risk management. Under the ESCB regime, it will be easier for a central bank to create adequate financial buffers in the case that risks are not sufficiently covered by capital and reserves or revaluation gains recorded in the balance sheet. On the other hand, IFRS focuses more on the relevance of the profit and loss figures. 


\section{Events after the Balance Sheet Date}

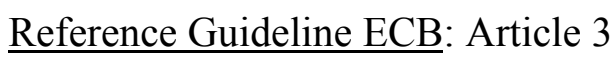

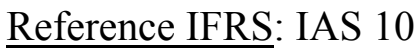

IFRS is far more detailed than the ECB Guideline, which nevertheless follows in principle the same logic as IAS 10.

\section{Recognition of Banknotes and Coins (legal tender)}

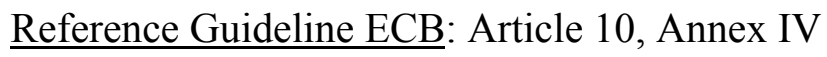

Under Article 10, the Guideline gives detailed rules for the calculation of the banknote in circulation item in the balance sheet. Annex IV specifies the presentation of banknotes and coins in the balance sheet. The accounting policies are referring to those banknotes and coins that are legal tender in the member states of the European Monetary Union.

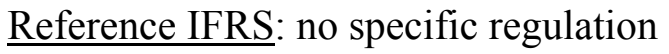

Covered under definition of liabilities in Framework.

\section{Sources:}

- ESCB: Guideline of the European Central Bank of 5 December, 2002 on the Legal Framework for Accounting and Financial Reporting in the European System of Central Banks (ECB/2002/10) as published in the Official Journal of the European Union (L 058 on March 3, 2003).

- IFRS/IAS: International Financial Reporting Standards/IAS 2004. 